EGG-WMO-10292

Revision 8

\title{
Preliminary Safety Analysis Report for the Transuranic Storage Area Retrieval Enclosure at the Idaho National Engineering Laboratory
}

\author{
DISCLAIMER
}

\begin{abstract}
This report was prepared as an account of work sponsored by an agency of the United States Government. Neither the United States Government nor any agency thereof, nor any of their employees, makes any warranty, express or implied, or assumes any legal liability or responsibility for the accuracy, completeness, or usefulness of any information, apparatus, product, or process disclosed, or represents that its use would not infringe privately owned rights. Reference herein to any specific commercial product, process, or service by trade name, trademark, manufacturer, or otherwise does not necessarily constitute or imply its endorsement, recommendation, or favoring by the United States Government or any agency thereof. The views and opinions of authors expressed herein do not necessarily state or reflect those of the United States Government or any agency thereof.
\end{abstract}

Published March 1993

\section{Idaho National Engineering Laboratory \\ EG\&G Idaho, Inc. \\ Idaho Falls, Idaho 83415}

\author{
Prepared for the \\ U.S. Department of Energy \\ Office of Environmental Restoration and Waste Management \\ Under DOE Idaho Field Office \\ Contract DE-AC07-76ID01570
}




\section{Approval Page}

\section{Preliminary Safety Analysis Report for the Transuranic Storage Area Retrieval Enclosure at the Idaho National Engineering Laboratory}

\section{Revision 8}

Approved By


Reviewed By






\section{ABSTRACT}

This Transuranic Storage Area Retrieval Enclosure Preliminary Safety Analysis Report was completed as required by DOE Order 5480.23. The purpose of this document is to construct a safety basis that supports the design and permits construction of the facility. The facility has been designed to the requirements of a Radioactive Solid Waste Facility presented in DOE Order 6430.1A. 


\section{CONTENTS}

ABSTRACT $\ldots \ldots \ldots \ldots \ldots \ldots \ldots \ldots \ldots \ldots \ldots \ldots \ldots \ldots \ldots \ldots \ldots \ldots \ldots \ldots \ldots$

ACRONYMS $\ldots \ldots \ldots \ldots \ldots \ldots \ldots \ldots \ldots \ldots \ldots \ldots \ldots \ldots \ldots \ldots \ldots \ldots \ldots$

1. INTRODUCTION $\ldots \ldots \ldots \ldots \ldots \ldots \ldots \ldots \ldots \ldots \ldots \ldots \ldots \ldots \ldots \ldots$

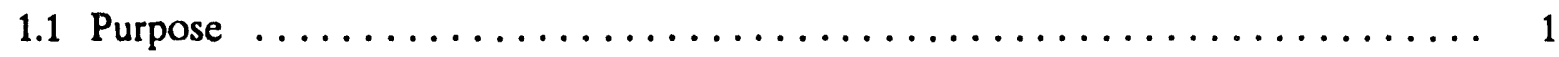

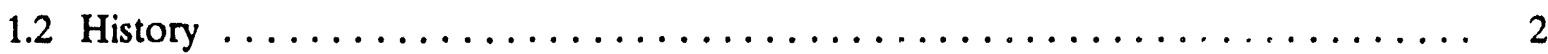

1.3 General Facility and Process Description $\ldots \ldots \ldots \ldots \ldots \ldots \ldots \ldots \ldots \ldots$

1.4 Summary of Additional Analyses to be Included in the FSAR $\ldots \ldots \ldots \ldots \ldots$

2. SUMMARY SAFETY ANALYSIS $\ldots \ldots \ldots \ldots \ldots \ldots \ldots \ldots \ldots \ldots \ldots \ldots$

2.1 Radiological Impacts from Normal Operations $\ldots \ldots \ldots \ldots \ldots \ldots \ldots$

2.2 Nonradiological Impacts from Normal Operations $\ldots \ldots \ldots \ldots \ldots \ldots$

2.3 Potential Hazards $\ldots \ldots \ldots \ldots \ldots \ldots \ldots \ldots \ldots \ldots \ldots \ldots \ldots \ldots \ldots$

2.4 Impacts from Accidents $\ldots \ldots \ldots \ldots \ldots \ldots \ldots \ldots \ldots \ldots \ldots \ldots \ldots$

3. SITE AND STORED WASTE CHARACTERISTICS $\ldots \ldots \ldots \ldots \ldots \ldots \ldots \ldots \ldots$

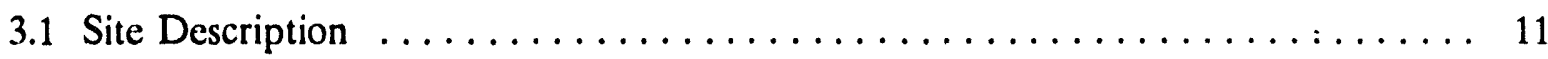



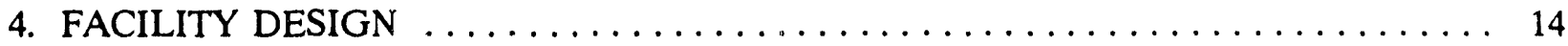

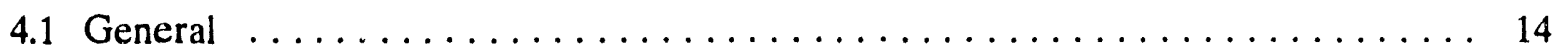

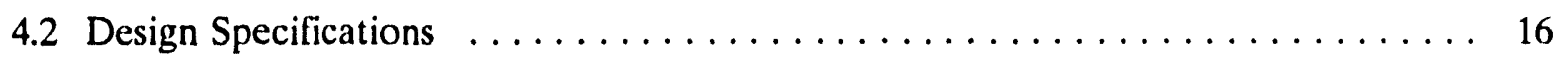



4.4 National Environmental Policy Act Compliance $\ldots \ldots \ldots \ldots \ldots \ldots \ldots \ldots$

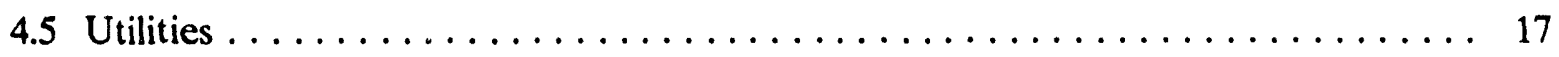

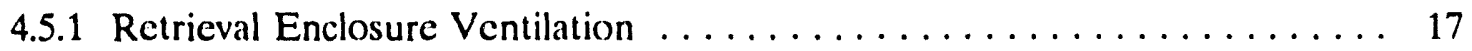

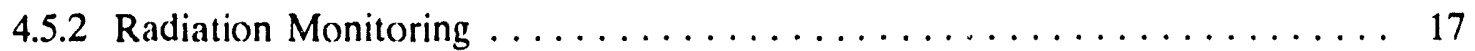

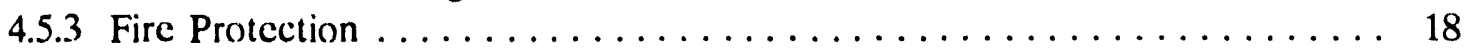






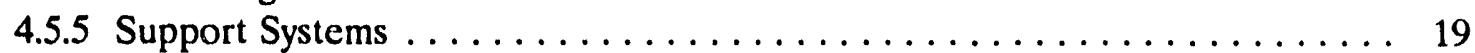

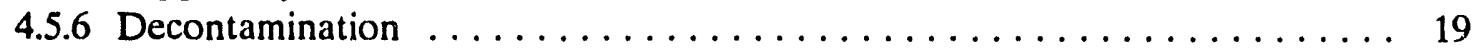

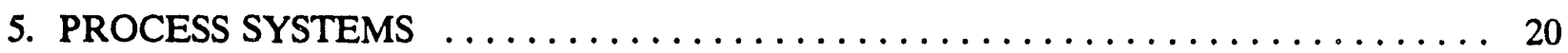

5.1 Overburden Removal Equipment $\ldots \ldots \ldots \ldots \ldots \ldots \ldots \ldots \ldots \ldots \ldots \ldots$

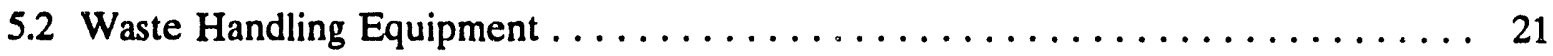



6. WASTE CONFINEMENT AND MANAGEMENT $\ldots \ldots \ldots \ldots \ldots \ldots \ldots \ldots \ldots 22$

7. HAZARDS PROTECTION $\ldots \ldots \ldots \ldots \ldots \ldots \ldots \ldots \ldots \ldots \ldots \ldots \ldots \ldots \ldots$

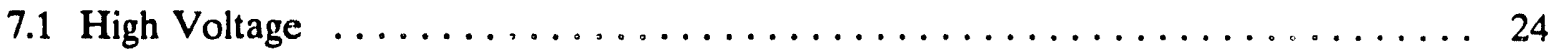

7.2 Flammable Gases, Liquids, and Dusts $\ldots \ldots \ldots \ldots \ldots \ldots \ldots \ldots \ldots \ldots \ldots$

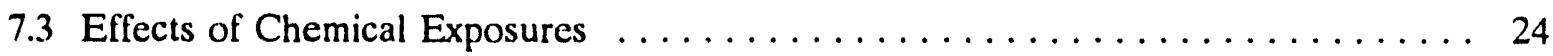

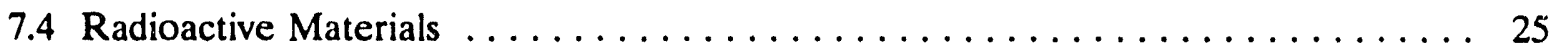

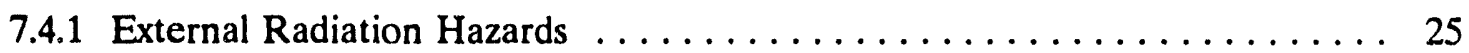

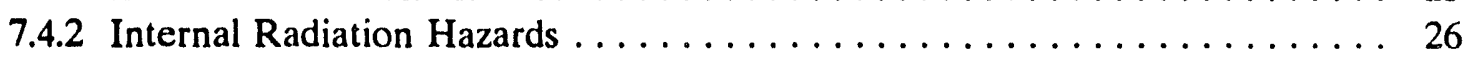







7.8 Mechanical and Moving Equipment Dangers $\ldots \ldots \ldots \ldots \ldots \ldots \ldots \ldots \ldots$

7.9 Inadequate Ventilation $\ldots \ldots \ldots \ldots \ldots \ldots \ldots \ldots \ldots \ldots \ldots \ldots \ldots \ldots \ldots \ldots \ldots$

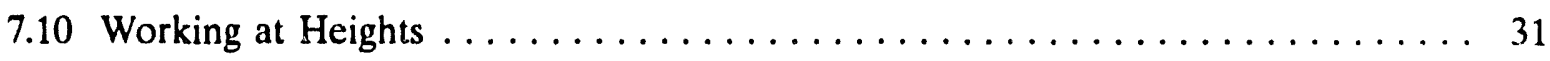

7.11 Material Handling Dangers $\ldots \ldots \ldots \ldots \ldots \ldots \ldots \ldots \ldots \ldots \ldots \ldots \ldots \ldots \ldots \ldots$



7.13 Inadequate Illumination $\ldots \ldots \ldots \ldots \ldots \ldots \ldots \ldots \ldots \ldots \ldots \ldots \ldots \ldots \ldots$






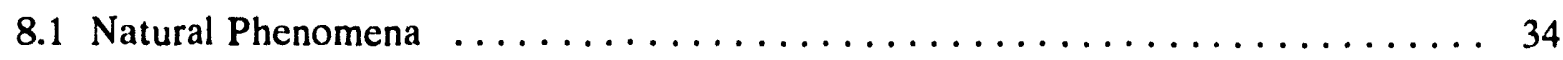

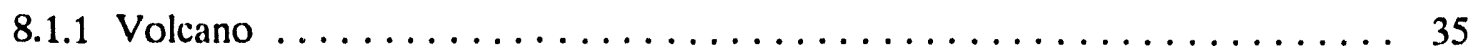

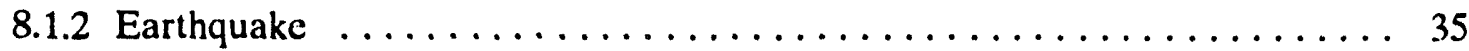

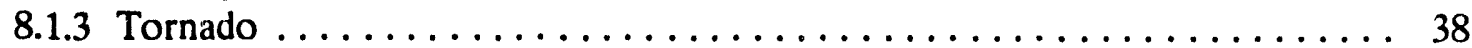

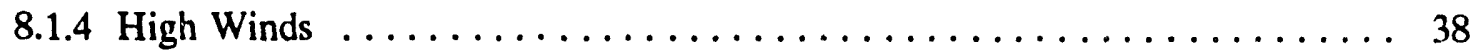



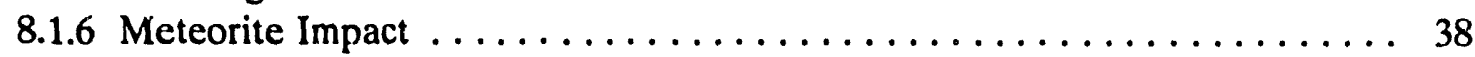



8.2 Operational Accidents $\ldots \ldots \ldots \ldots \ldots \ldots \ldots \ldots \ldots \ldots \ldots \ldots \ldots \ldots \ldots \ldots$

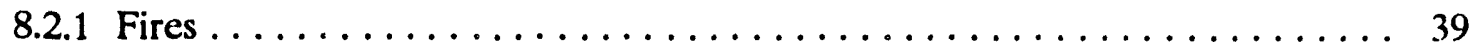

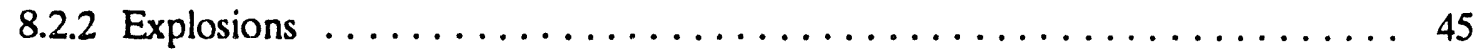



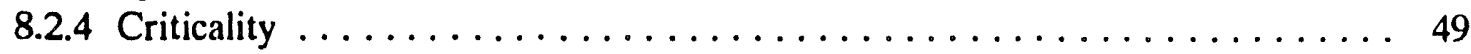

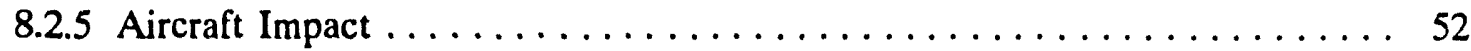

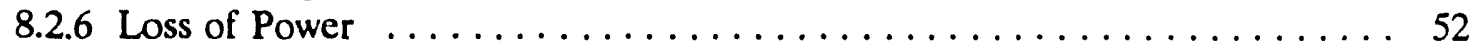

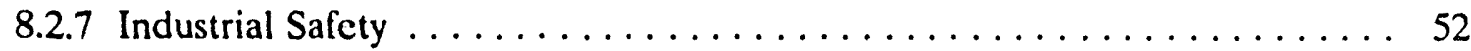

8.3 Construction Accidents $\ldots \ldots \ldots \ldots \ldots \ldots \ldots \ldots \ldots \ldots \ldots \ldots \ldots \ldots \ldots$

8.4 Bounding Accident Summary $\ldots \ldots \ldots \ldots \ldots \ldots \ldots \ldots \ldots \ldots \ldots \ldots$

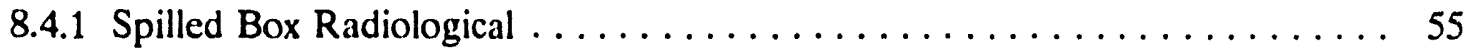





8.4 .4 Drum Explosion and Fire $\ldots \ldots \ldots \ldots \ldots \ldots \ldots \ldots \ldots \ldots \ldots$

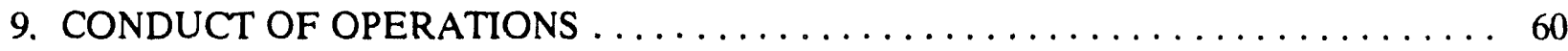

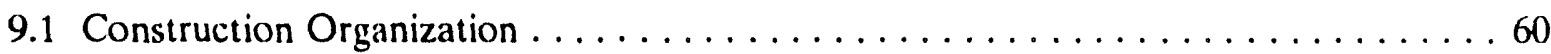



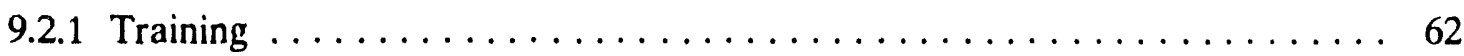

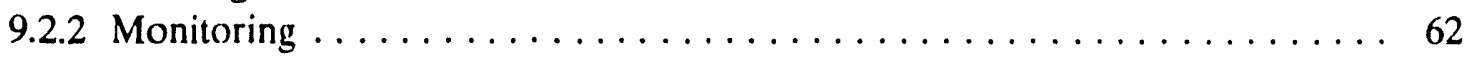

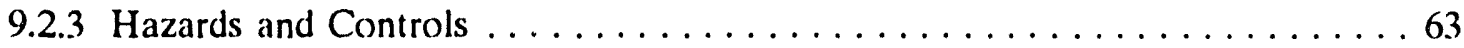

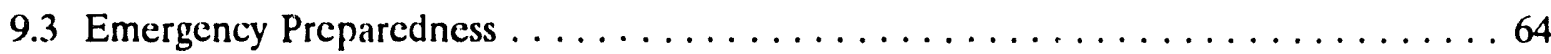

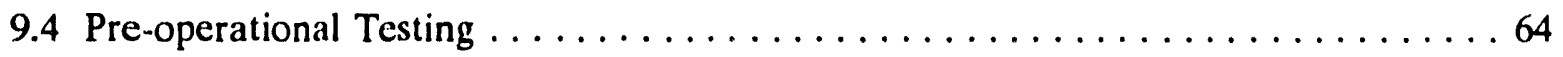

10. OPERATIONAL SAFETY REQUIREMENTS $\ldots \ldots \ldots \ldots \ldots \ldots \ldots \ldots \ldots \ldots$

10.1 Limiting Conditions of Operations $\ldots \ldots \ldots \ldots \ldots \ldots \ldots \ldots \ldots \ldots \ldots \ldots \ldots \ldots \ldots \ldots \ldots$ 
10.1.1 Definition .................................. 65





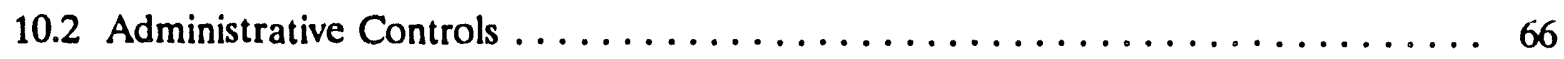

10.2.1 Definition ................................66 66

10.2.2 Preliminary Administrative Control List $\ldots \ldots \ldots \ldots \ldots \ldots \ldots 66$

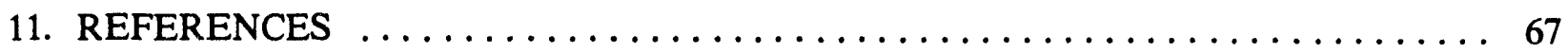

Appendix A-Tentative Hazard Classification $\ldots \ldots \ldots \ldots \ldots \ldots \ldots \ldots \ldots \ldots \ldots \ldots \ldots \ldots \ldots$

FIGURES

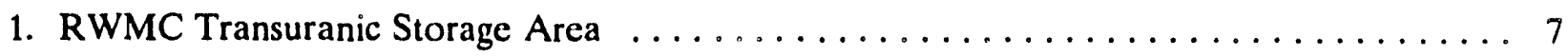

2. Diagram of the smaller work area in the RE. $\ldots \ldots \ldots \ldots \ldots \ldots \ldots \ldots \ldots \ldots \ldots$

3. Distribution of grams of fissile material in waste containers $\ldots \ldots \ldots \ldots \ldots \ldots \ldots 27$

4. TSA-RE construction organization chart $\ldots \ldots \ldots \ldots \ldots \ldots \ldots \ldots \ldots \ldots \ldots \ldots \ldots \ldots \ldots \ldots$

\section{TABLES}

1. Average annual hazardous constituents emissions from the RE $\ldots \ldots \ldots \ldots \ldots$

2. Identilication of hazards within the $\mathrm{RE} \ldots \ldots \ldots \ldots \ldots \ldots \ldots \ldots \ldots \ldots \ldots \ldots \ldots \ldots$

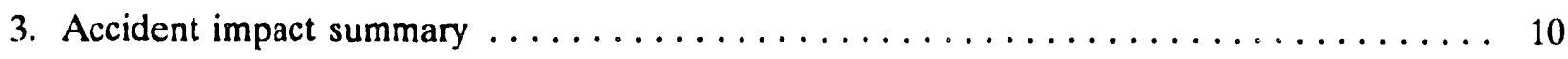



5. Radionuclide releases because of normal operations of the RE ............ 29

6. Calculated dose consequences of routine releases from the RE $\ldots \ldots \ldots \ldots \ldots \ldots 29$

7. Natural phenomena accident scenarios presented in the RWMC SAR $\ldots \ldots \ldots \ldots 34$

8. Average container headspace concentrations and airborne releases $\ldots \ldots \ldots \ldots \ldots . \ldots 37$

9. Average airborne particulate releases for a structural earthquake $\ldots \ldots \ldots \ldots \ldots . \ldots 37$

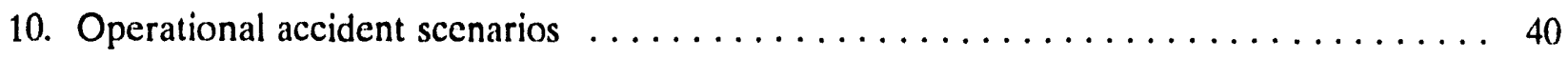

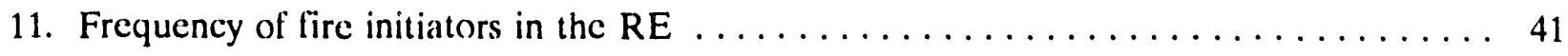




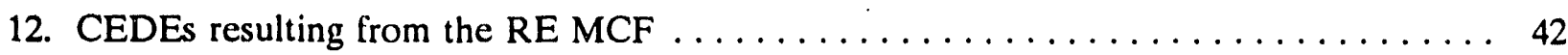

13. Hazardous constituent release rates from the $\mathrm{RE} \mathrm{MCF} . \ldots \ldots \ldots \ldots \ldots \ldots$

14. Hazardous constituent concentrations from the $\mathrm{RE} \mathrm{MCF} \ldots \ldots \ldots \ldots \ldots \ldots$

15. Radionuclide releases for the dropped box accident $\ldots \ldots \ldots \ldots \ldots \ldots \ldots \ldots$

16. CEDEs resul ${ }^{\wedge}$.ng from dropped box accidents $\ldots \ldots \ldots \ldots \ldots \ldots \ldots \ldots \ldots$

17. Average container headspace concentrations and releases of VOCs $\ldots \ldots \ldots \ldots \ldots$

18. Average source terms and airborne particulate releases $\ldots \ldots \ldots \ldots \ldots \ldots \ldots$

19. TLV-based HIs resulting from the dropped box accident scenario $\ldots \ldots \ldots \ldots \ldots$






\section{ACRONYMS}

$\begin{array}{ll}\text { A-E } & \text { Architectural Engineering (Standard) } \\ \text { ASWS } & \text { air support weather shield } \\ \text { BAS } & \text { Breathing Air System } \\ \text { BEIR } & \text { Biological Effects of Ionizing Radiation } \\ \text { CAM } & \text { constant air monitor } \\ \text { CEDE } & \text { committed effective dose equivalent } \\ \text { CH } & \text { contact handled } \\ \text { COOM } & \text { (EG\&G Idaho) Conduct of Operations Manual } \\ \text { DBA } & \text { design basis accident } \\ \text { DOE } & \text { U.S. Department of Energy } \\ \text { DOE-ID } & \text { U.S. Department of Energy Idaho Field Office } \\ \text { E\&CM } & \text { Engineering and Construction Management (Group) } \\ \text { EA } & \text { environmental assessment } \\ \text { EBR-I } & \text { Experimental Breeder Reactor No. 1 } \\ \text { EDE } & \text { effective dose equivalent } \\ \text { EPA } & \text { U.S. Environmental Protection Agency } \\ \text { ESH\&Q } & \text { Environment, Safety, Health, and Quality } \\ \text { FM } & \text { Factory Mutual } \\ \text { FRP } & \text { fiberglass reinforced plywood } \\ \text { FSAR } & \text { final safety analysis report } \\ \text { H\&S } & \text { health and safety } \\ \text { HEPA } & \text { high efficiency particulate air (filter) } \\ \text { HI } & \text { hazard index } \\ \text { HWMA } & \text { Hazardous Waste Management Act } \\ \text { IDLH } & \text { immediately dangerous to life or health } \\ \text { INEL } & \text { Idaho National Engincering Laboratory } \\ \text { LCO } & \text { limiting conditions of operations } \\ \text { LLW } & \text { low-level waste } \\ \text { MCE } & \text { maximum credible explosion } \\ \text { MCF } & \text { maximum credible fire } \\ \text { MCFL } & \text { maximum credible flood } \\ \text { MK-FIC } & \text { Morrison Knudsen-Ferguson of Idaho Company } \\ \text { NEPA } & \text { National Environmental Policy Act } \\ \text { NFPA } & \text { National Fire Protection Association } \\ \text { NRC } & \text { U.S. Nuclear Regulatory Commission } \\ \text { O\&MM } & \text { Operations and Maintenance Manual } \\ \text { OSHA } & \text { Occupational Safety and Health Administration } \\ \text { OSR } & \text { Operational Safety Requirement } \\ \text { PCB } & \text { polychlorinated biphenyl } \\ \text { PPE } & \text { personnel protective equipment } \\ \text { PSAR } & \text { preliminary safety analysis report } \\ \text { RAM } & \text { remote area monitor } \\ \text { RCRA } & \text { Resource Conservation and Recovery Act } \\ \text { RE } & \text { Retrieval Enclosure } \\ & \end{array}$


RWMC Radioactive Waste Management Complex

RWMIS Radioactive Waste Management Information System

SAR safety analysis report

SDA

Subsurface Disposal Area

STEL

SWEPP

short-term exposure limit

TLV

TRU

Stored Waste Examination Pilot Plant

TSA threshold limit value

TSCA

transuranic

Transuranic Storage Area

TSD

Toxic Substances Control Act

TSR

Treatment, Storage, and Disposal (site)

TWA

Technical Safety Requirement

UBC

time-weighted average

UCRL

UL

VOC

WM

Uniform Building Code

University of California Research Laboratories

Underwriters Laboratory

volatile organic compound

Waste Management (Programs)

WSF

Waste Storage Facility 


\section{Preliminary Safety Analysis Report for the Transuranic Storage Area Retrieval Enclosure at the Idaho National Engineering Laboratory}

\section{INTRODUCTION}

This document is a Preliminary Safety Analysis Report (PSAR) with the purpose of assessing the safety adequacy of design features and systems within the retrieval enclosure to assure the facility is constructed to meet its objectives. Therefore, only those issues directly related to the design and construction of the Transuranic Storage Area (TSA) Retrieval Enclosure (RE) have been addressed in detail. Operations-related concerns, although considered in the design and addressed in this document in general detail, will be addressed in detail in the Final Safety Analysis Report (FSAR). Section 1.4 summarizes areas that have been deferred until the FSAR.

This version of the PSAR was originally prepared to the requirements of DOE Order 5481.1B, "Safety Analysis and Review Systems (for nuclear facilities)," and has recently been upgraded to meet DOE Order 5480.23, "Nuclear Safety Analyses Reports." The FSAR will meet the format and content requirements of DOE Order 5480.23.

The TSA-RE project is currently in compliance with all applicable safety and quality related DOE orders. These orders are implemented through EG\&G Idaho, Inc. Company manuals and procedures. These manuals and procedures are periodically reviewed to assure that they adequately address new DOE orders and requirements and correct audit findings. For example, the EG\&G Idaho Quality Manual has been revised to incorporate requirements of the new DOE Order 5700.6C, "Quality Assurance." Other important DOE orders being met are

- DOE Order 4700.1, "Project Management Systems"

- DOE Order 6430.1A, "General Design Criteria"

- DOE Order 5480.19, "Conduct of Operations."

Operations concerns related to design and construction are outlined in the EG\&G Idaho Conduct of Operations Manual, and Waste Management Department procedures. Conduct of Operations will be addressed in detail in the FSAR (see Chapter 9 for a brief introduction).

\subsection{Purpose}

The purpose of the RE is to provide a work area that will allow year-round retrieval of mixed transuranic (TRU) waste presently stored on asphalt pads within the TSA. The waste retrieval facility is intended to delay further deterioration of the waste containers presently stored in the TSA and to provide equipment and systems to begin waste management activities in preparation for future offsite waste transportation to final waste disposal facilities. 


\subsection{History}

The RWMC has been a depository for radioactive waste since 1952, accepting waste from the Rocky Flats Plant in Colorado and nuclear facilities throughout the United States, including waste from the Idaho National Engineering Laboratory (INEL). Since 1970, TRU waste, as defined in DOE Order 5820.2A, has been placed in retrievable storage at the RWMC under the assumption that the waste will be retrieved and transported to a permanent repository within 20 years.

DOE's strategy for long-term management of mixed TRU and LLW stored at the INEL and other DOE facilities is to retrieve, examine, and categorize the waste; perform appropriate treatment and repackaging to meet transportation and disposal waste acceptance criteria; and transport the waste to DOE's Waste Isolation Pilot Plant (a research and development facility to demonstrate the safe disposal of radioactive waste) or to a shallow land burial site if treated and rendered LLW.

\subsection{General Facility and Process Description}

The TSA is an area within the RWMC that is an operating facility within the INEL. The RWMC covers approximately 144 acres located near the center of the eastern Snake River Plain. Since 1970, contact-handled $(\mathrm{CH})$ TRU contaminated waste has been stored on ground level asphalt pads within the TSA. This waste was primarily generated by operations conducted for DOE and its predecessors in support of defense programs.

On two of the asphalt pads the waste was placed in an assortment of containers that were stacked neatly and covered with a plywood cover, fabric, and 3 to $4 \mathrm{ft}$ of soil. On another pad the waste containers were neatly stacked and covered with fabric only. These storage configurations do not meet Resource Conservation and Recovery Act (RCRA) criteria and need to be reworked to meet the criteria. The TSA-RE will provide a weather tight enclosure over these three pads of waste containers which will permit retrieval of the waste for restorage into a RCRA-approved configuration.

The enclosure to be constructed over these three pads is a pre-engineered metal building meeting requirements of DOE Order 6430.1A for Radioactive Solid Waste Facilities. Specific facility and operating requirements are documented in the Functional and Operational Requirernents document.

The largest portion of the building covering pads TSA-1 and TSA-R is approximately $1,175 \mathrm{ft}$ long with a free span of $200 \mathrm{ft}$. An annex to the main building is provided to cover pad TSA-2 and is approximately $475 \mathrm{ft}$ long with a free span of $186 \mathrm{ft}$. The building covers an area approximately $313,000 \mathrm{ft}^{2}$.

Two moving walls (shrouds) are provided vithin the building to define the work area and the only ventilated area of the building. The shrouds are positioned $200 \mathrm{ft}$ apart at bulkheads built into the building. These bulkheads provide connections for power, lighting, breathing air, and ventilation. Air enters the work area through the trailing shroud and is exhausted from the work area through the leading shroud. The exhaust air flow is greater than the incoming airtlow rate to keep the work area at a negative pressure and to account for leakage through building openings. The airflow is also 
directed from a clean area to a potentially contaminated area for protection of the workers. The work area is also provided with 12 breathing air station in the event that an off-normal event occurs.

The enclosure is provided with a monitoring and control station. This station collects information from systems to measure their operating conditions. Examples of the information collected at this station are high efficiency particulate air (HEPA) filter pressure drop, work area pressure, breathing air pressure, electrical power consumption, stack and area radiation monitoring status, and visual monitoring of the work area.

Overburden soils and waste containers will be removed inside the work area defined by the two shrouds. This operation uses several pieces of equipment. One key piece of equipment is an excavator class machine equipped for using six different end effectors. End effectors consist of standard bucket, two forklifts, a barrel handler, a SAND box lift fixture, and a hook for handling M-III bins. A vacuum system is another key piece of equipment that will be used to remove overburden and interstitial soils and for general housekeeping. To minimize the potential of personnel contamination, the work area, soils and containers will be constantly measured for radiological and hazardous contaminates. In the event that a contaminated or structurally weak waste container is found, a mobile isolation unit will be positioned over the suspect container to permit safe overpacking or decontamination. The Isolation Unit is designed to be used with the excavator and is provided with an exhaust HEPA filter system.

To perform the retrieval tasks, the earth overburden covering the waste stacks shall be sampled and scanned for contamination before removal. The waste containers will be visually examined for degradation and radiologically surveyed for measurable contamination while in the stack. The containers will then be removed from the stack, surveyed for contamination, visually examined to determine the physical condition of the container, and overpacked as necessary. The containers will then be loaded on a truck and transported to the Waste Storage Facility (WSF).

\subsection{Summary of Additional Analyses to be Included in the FSAR}

Several items discussed in this PSAR are incomplete; these items deal primarily with operational activities and requirements and have little or no impact on the facility design. This information will be completed and included in the FSAR. The following is a summary of areas which will be more completely addressed in the FSAR:

- The current retrieval process (Section 5) is based on a conceptual retrieval process. A fully developed retrieval process will be presented in the FSAR.

- Industrial hazards (Section 7) will be developed and included in the FSAR after the procedures and equipment have been finalized.

- The potential for accumulation and explosion of hydrogen or flammable liquid vapors in the isolation unit is being evaluated (Section 8.2.2). Any changes to the design of this unit, which will not affect the RE design, will be included in the FSAR.

- $\quad$ Conduct of Operations (Section 9) detail will be included in the FSAR. 
- The bases for development of Technical Safety Requirements (TSRs) prepared in accordance with DOE Order 5480.22.

- Potential propane tank accidents, particularly the boiling liquid expanding vapor explosion (BLEVE), will be addressed in the FSAR.

- The potential for, consequences of, and prevention/mitigation factors for the Maximum Credible Fire are being reassessed and will be more fully developed in the FSAR. This PSAR provides current approaches to fire prevention/mitigation as well as bounding consequence calculations. A more refined approached is proposed for the FSAR. 


\section{SUMMARY SAFETY ANALYSIS}

The RE has been determined to be a Category 2 Hazard Classification activity as defined by the criteria specified in DOE Order 5480.23. The Tentative Hazard Classification determination has been included as Appendix A.

The RE represents a low probability risk, even for an already low risk operation such as LLW and limited TRU handling. Only sufficient waste containers will be exposed at any one time to allow removal, inspection and any necessary repackaging. Significant waste will not be stored in the RE building, but will be removed to more permanent storage facilities. The most significant hazards will be either handling accidents of single boxes/drums or postulated damage to exposed faces of boxes or drums. Accordingly, consistent with the graded approach of DOE Order 5480.23, hazard effects calculations in this PSAR either reference more conservative calculations in the RWMC SAR (1986) or use broadly conservative assumptions. Additionally, bounding calculations are provided for a number of events where the estimated probability of occurrence (Ebasco 1990) exceeds the 1.0E-06/yr normally associated with credible occurrences. Again, this approach is taken to demonstrate that even for these events of diminishingly small probability of occurrence calculated hazards are not excessive. This conservative approach is taken to minimize the PSAR analysis costs for this remote facility (graded approach). The results of these analyses do not necessarily relate to other similar facilities at other locations or to other facilities at the RWMC. In some cases, particularly to assure worker safety, more detailed evaluations and associated mitigation strategies may be presented in the FSAR.

Routine operating emissions will be below the allowable emission limits for both radiological and hazardous materials. All accident scenarios defined in the RWMC SAR or presented in this PSAR lead to acceptable consequences to facility workers, workers at co-located facilities and to the general public.

\subsection{Radiological Impacts from Normal Operations}

The proposed retrieval operations have releases of radioactive material calculated to be 2.3E-8 Ci/yr. These releases will add a maximum of $3.2 \mathrm{E}-07 \mathrm{mrem} / \mathrm{yr}$ to the current INEL off-site CEDE. For an area within a 50-mi radius from the operations center of the INEL, radioactive emissions from the proposed action will, at a maximum, add $2.1 \mathrm{E}-07$ person-rem/yr to the collective off-site CEDE of 1.7E+00 person-rem from INEL activities (Abbott 1990).

\subsection{Nonradiological Impacts from Normal Operations}

Estimated hazardous material emissions from the RE that result from breached waste containers were calculated and compared to applicable standards to determine the potential impact of routine operations on air quality. Hazardous constituents of the waste were assumed to be those identified in Clements (1982). Table 1 provides calculated concentrations of hazardous constituents at three locations because of emissions from the RE (DOE 1992a). The estimated airborne concentrations are low enough to present no health hazard to workers in the enclosure or to the public. 
Table 1. Average annual hazardous constituents emissions from the RE (DOE 1992a).

\begin{tabular}{|c|c|c|c|c|}
\hline Constituent & $\begin{array}{l}\text { WMF-613 } \\
\left(\mu \mathrm{g} / \mathrm{m}^{3}\right)\end{array}$ & $\begin{array}{l}\text { EBR-I } \\
\left(\mu \mathrm{g} / \mathrm{m}^{3}\right)\end{array}$ & $\begin{array}{l}\text { Site boundary } \\
\quad\left(\mu \mathrm{g} / \mathrm{m}^{3}\right)\end{array}$ & $\begin{array}{l}\text { TWATIV } \\
\left(\mu \mathrm{g} / \mathrm{m}^{3}\right)\end{array}$ \\
\hline 1,1,1-Trichloromethane & $9.2 \mathrm{E}-04$ & 8.2E-04 & 4.5E-04 & $1.9 \mathrm{E}+06$ \\
\hline Carbon tetrachloride & $9.9 \mathrm{E}-04$ & 8.8E-04 & 4.8E-04 & $3.1 E+04$ \\
\hline $\begin{array}{c}\text { 1,1,2-trichloro-1,2,2 } \\
\text { trifluoroethane }\end{array}$ & $5.9 \mathrm{E}-04$ & $5.2 \mathrm{E}-04$ & $2.8 \mathrm{E}-04$ & $7.7 \mathrm{E}+06$ \\
\hline Trichloroethylene & $6.2 \mathrm{E}-04$ & $5.5 \mathrm{E}-04$ & $3.0 \mathrm{E}-04$ & $2.7 \mathrm{E}+05$ \\
\hline Perchloroethylene & $1.0 \mathrm{E}-04$ & $9.0 \mathrm{E}-05$ & $5.0 \mathrm{E}-05$ & $3.4 \mathrm{E}+05$ \\
\hline Methylene chloride & $6.0 \mathrm{E}-05$ & $6.0 \mathrm{E}-05$ & 3.0E-05 & $1.7 E+05$ \\
\hline Methyl alcohol & $1.0 \mathrm{E}-06$ & $1.0 \mathrm{E}-06$ & $6.0 \mathrm{E}-07$ & $2.6 \mathrm{E}+05$ \\
\hline Butyl alcohol & $5.0 \mathrm{E}-07$ & $4.0 \mathrm{E}-07$ & $2.0 \mathrm{E}-07$ & $3.0 \mathrm{E}+05$ \\
\hline Xylene & $3.0 \mathrm{E}-06$ & $3.0 \mathrm{E}-06$ & $2.0 \mathrm{E}-06$ & $4.3 E+05$ \\
\hline Lead & $1.3 \mathrm{E}-10$ & $1.2 \mathrm{E}-10$ & $6.3 \mathrm{E}-11$ & $1.5 \mathrm{E}+02$ \\
\hline Cadmium & $4.8 \mathrm{E}-14$ & $4.2 \mathrm{E}-14$ & $2.3 E-14$ & $5.0 \mathrm{E}+01$ \\
\hline Beryllium & $3.3 \mathrm{E}-12$ & $3.0 \mathrm{E}-12$ & $1.6 \mathrm{E}-12$ & $2.0 \mathrm{E}+00$ \\
\hline Asbestos & 2.2E-11 & $2.0 \mathrm{E}-11$ & $1.1 \mathrm{E}-11$ & $2.0 \mathrm{E}+02$ \\
\hline
\end{tabular}

a. WMF-613. Waste Management Facility Office Building (see Figure 1 for location). This building is $137 \mathrm{~m}(450 \mathrm{ft})$ northeast of the TSA.

b. EBR-I. Experimental Breeder Reactor No. 1 (Historical Monument open to the public during part of the year), which is located approximately $3 \mathrm{~km}(1.9 \mathrm{mi})$ east of the $\mathrm{RE}$.

c. Site boundary. Rest stop on Highway 26 , which is located approximately $6 \mathrm{~km}$ ( $3.7 \mathrm{mi})$ northwest of the RE.

d. American Conference of Government Industrial Hygienists. Threshold Limit Values for Chemical Substances and Physical Agents and Biological Exposure Limits, 1990-1991. 


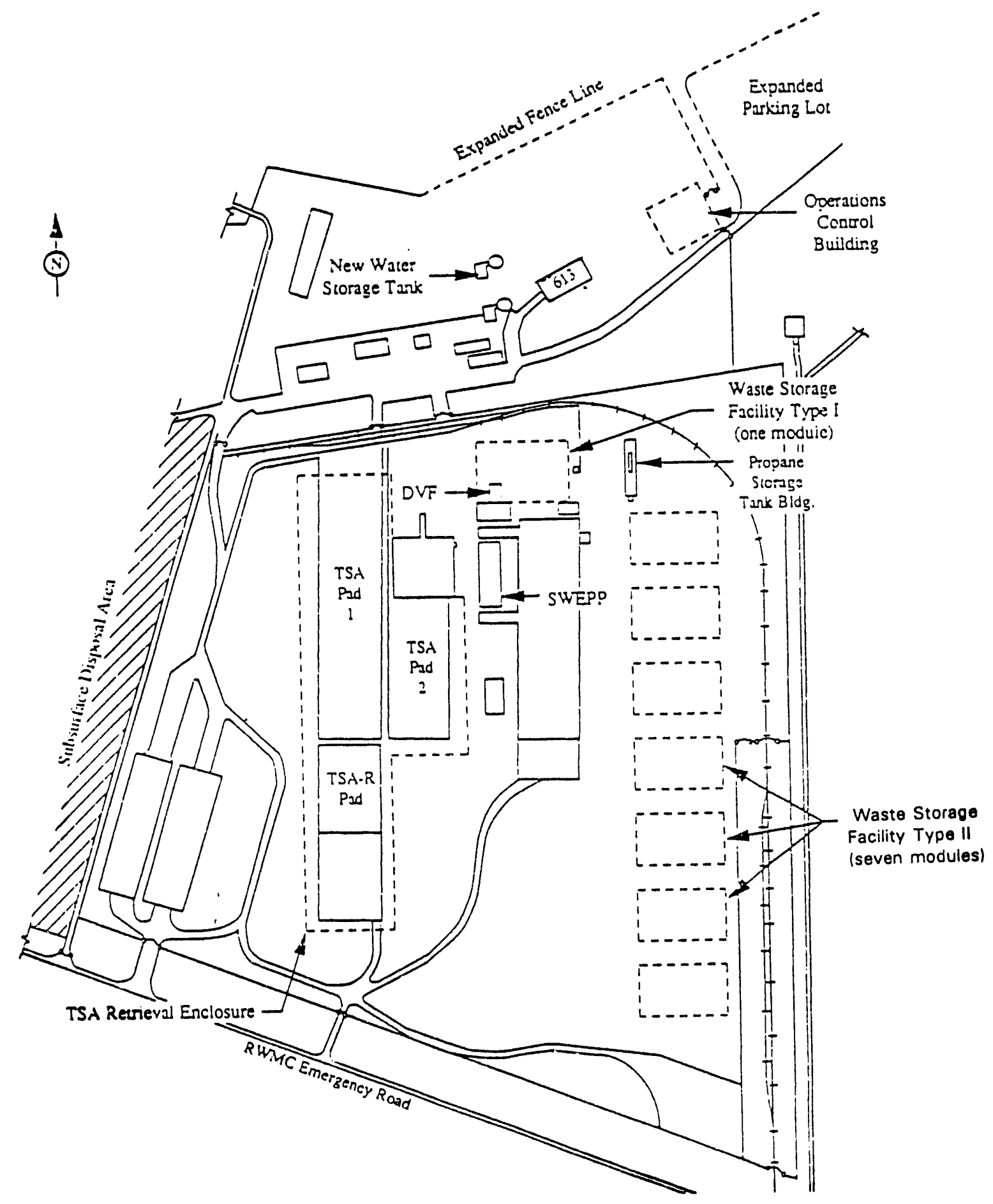

Figure 1. RWMC Transuranic Storage Area. 
Estimated hazardous emissions from normal operations are based on averages. Monitoring and related procedures will be in place to ensure guidelines are not exceeded.

\subsection{Potential Hazards}

Potential hazards associated with the activities within the RE were systematically identified using the criteria presented in the EG\&G Idaho Safety Manual (EG\&G 1988). The individual hazards are identified in Table 2, followed by the applicability of the hazard within the RE. Those hazards that were deemed to be applicable are addressed in detail in Section 7. All of these hazards will be minimized by applying appropriate preventive and mitigative measures. These measures are discussed in Section 7.

\subsection{Impacts from Accidents}

Natural phenomena and a number of operational accidents could result in damage to the RE and/or releases of radioactivity and hazardous chemicals. Table 3 summarizes the radiological doses and total hazard indices (HIs) from a spectrum of severe postulated accidents, which are presented in detail in Section 8. 
Table 2. Identification of hazards within the RE.

Hazard

High voltage

Flammable gases, liquids, and dust

Explosive substances ${ }^{\mathbf{a}}$

Compressed gases

Cryogenic systems

High temperature/pressure systems

Inert/low oxygen atmospheres

Nonionizing radiation sources

Effects of chemical exposures

Radioactive materials

Nuclear criticality

High intensity magnetic fields

High noise levels

Toxic and noxious emissions

Mechanical and moving equipment dangers

Inadequate ventilation

Working at heights

Material handling dangers

Pesticide use

Temperature extremes

Inadequate illumination
Applicability

Applicable

Applicable

Not applicable

Not applicable

Not applicable

Not applicable

Not applicable

Not applicable

Applicable

Applicable

Applicable

Not applicable

Applicable

Applicable

Applicable

Applicable

Applicable

Applicable

Not applicable

Applicable

Applicable

a. This refers to explosive material such as dynamite. Propane tank and waste drum explosions are considered under flammable gases. 
Table 3. Accident impact summary.

\begin{tabular}{|c|c|c|c|c|c|}
\hline \multirow[b]{2}{*}{ Accident scenario } & \multicolumn{2}{|c|}{ Onsite } & \multicolumn{2}{|c|}{ Offsite } & \multirow[b]{2}{*}{$\begin{array}{r}\text { Probability } \\
\text { (per year) }\end{array}$} \\
\hline & $\begin{array}{l}\text { Limit } \\
\text { (rem) }\end{array}$ & $\begin{array}{l}\text { Consequences } \\
\text { (rem) }\end{array}$ & $\begin{array}{l}\text { Limit } \\
\text { (rem) }\end{array}$ & $\begin{array}{c}\text { Consequences } \\
\text { (rem) }\end{array}$ & \\
\hline \multicolumn{6}{|l|}{ Fires } \\
\hline Radiological CEDE & $5.0 \mathrm{E}+00$ & $2.8 \mathrm{E}+01(100 \mathrm{~m})$ & $5.0 \mathrm{E}-01$ & $3.9 \mathrm{E}-01$ & $3.0 \mathrm{E}-06$ \\
\hline Hazard indices & $<1.0 \mathrm{E}+00$ & $4.1 \mathrm{E}+00$ & $<1.0 \mathrm{E}+00$ & $9.2 \mathrm{E}-03$ & \\
\hline \multicolumn{6}{|l|}{ Dropped box inside RE } \\
\hline Radiological CEDE & $5.0 \mathrm{E}+00$ & $4.9 \Gamma:+\infty 0$ & $5.0 \mathrm{E}-01$ & a & $6.0 \mathrm{E}-03$ \\
\hline Hazard indices & $<1.0 \mathrm{E}+00$ & $6.2 \mathrm{E}-02$ & $<1.0 \mathrm{E}+00$ & & \\
\hline \multicolumn{6}{|l|}{ Dropped box outside } \\
\hline Radiological CEDE & $5.0 \mathrm{E}+00$ & $2.1 \mathrm{E}+\infty 0$ & $5.0 \mathrm{E}: i$ & $4.5 \mathrm{E}-03$ & $1.2 \mathrm{E}-02$ \\
\hline Hazard indices & $<1.0 \mathrm{E}+00$ & $2.2 \mathrm{E}-02$ & $<1.0 \mathrm{E}+00$ & $1.4 \mathrm{E}-02$ & \\
\hline
\end{tabular}




\section{SITE AND STORED WASTE CHARACTERISTICS}

\subsection{Site Description}

The INEL Site is located in southeastern Idaho, at the foot of the Big Lost River, Lemhi, and Beaverhead Mountain Ranges and along the edge of the Eastern Snake River Plain. Although the INEL Site extends into Bingham, Bonneville, Jefferson, and Clark Counties, it lies mostly in Butte County, Idaho.

The RWMC is located in the southwest corner of the INEL, $3.5 \mathrm{mi}$ north of the southern boundary of the INEL, 54 mi west of Idaho Falls, and about 22 mi southeast of Arco. It is situated in a shallow depression surrounded on three sides by low hills, includes approximate'v 144 acres of level ground, and lies at an elevation of about 5,000 ft above mean sea level (. inderson and Lewis 1989).

Numerous studies have documented the geology, geography, hydrology, and meteorology of the RWMC. Section 3, of the RWMC SAR (EG\&G 1986) summarizes information from these studies. This section also provides information related to the demography of the Site and identifies surrounding industrial, transportation, and military facilities. Additional information about the RWMC can be found in Berry and Petty (1990). There are no site characteristics that will adversely affect construction or operation of the RE.

The TSA-RE is located just to the west of the center of the TSA. The Subsurface Disposal Area (SDA) is located approximately $500 \mathrm{ft}$ to the west and isolated from the TSA by a fence. During normal operating conditions, the SDA will not have any affect on the operation of the TSA-RE. To the east of the TSA-RE is the TRUPACT loading station and the Stored Waste Examination Pilot Plant (SWEPP). This is an operating area; during construction, coordination of construction and operating activities will be required. During normal operation of the TSA-RE, however, there will be no affect of the these facilities on the operation of the TSA-RE.

Siting characteristics that impact the design of the TSA-RE are flooding, seismic activity, extreme temperatures, high winds, snow load, and lightning storms. As evidenced by past events, the RWMC lies in an area subject to periodic flooding. This is of concern because tlooding may enhance migration of radionuclides and other hazardous materials beneath the facility. To date, extensive efforts have been undertaken to minimize the potential for future tlooding. The RWMC Flood Diversion System has been analyzed for floods with an estimated return period of up to 10,000 years. Because the Flood Diversion System is the primary protection against facility tlooding, the system is required, administratively, to be maintained in an operable condition throughout the year. Maintaining operability includes removing debris from all RWMC tlood diversion channels and verifying operability of all head gates. Additionally, all construction at the RWMC is and will continue to be analyzed for potential flooding.

Although extremely rare at the INEL, seismic activity has frequently occurred in the surrounding mountains north and west of the INEL, and future earthquakes are anticipated in those areas. These events have not resulted in any damage to the RWMC facilities or any other facilities on the INEL. However, to minimize the consequences of these potential events, the construction of the TSA-RE 
will conform to Uniform Building Code (UBC) and University of California Research Laboratories (UCRL) 15910 requirements (see Section 4.2).

Weather conditions at the RWMC can be extreme. Temperatures as low as $-30^{\circ} \mathrm{F}\left(-34^{\circ} \mathrm{C}\right)$ or as high as $100^{\circ} \mathrm{F}\left(38^{\circ} \mathrm{C}\right)$ are not uncommon nor are wind speeds in excess of $50 \mathrm{mph}(80 \mathrm{~km} / \mathrm{h})$. Winds are not expected to exceed the design criteria of $80 \mathrm{mph}$. The recorded maximum 24-hour snowfall at INEL is 8.6 inches. The recorded maximum accumulation on level ground is 25 inches which is substantially below the $30 \mathrm{lb} / \mathrm{ft}^{2}$ snow loading design criteria. Snow removal actions are taken when required. These weather conditions are considered in all construction projects at the RWMC.

Severe thunderstorms accompanied by lightning and high winds do occur during the summer months; therefore, consideration must be given to the potential for credible lightning strikes where postulated consequences are severe. However, because tornado formation is rare, no special design considerations are imposed for building construction to account for the potential effects of a tornado.

\subsection{Stored Waste Description}

Mixed TRU and LLW at the RWMC TSA are stored in metal bins and boxes, fiberglass reinforced plywood (FRP) boxes, wooden storage boxes, and 30-, 55-, and 83-gal stecl drums stacked approximately $16 \mathrm{ft}$ high on three above-ground asphalt pads (TSA-1, TSA-2, and TSA-R). (see Figure 1). The TSA-RE will cover waste located on pads TSA-1, -2, and -R. Approximately $80 \%$ of the waste is stored on pads covered with 3 to $4 \mathrm{ft}$ of soil overburden or fabric tarpaulin. The remaining mixed TRU and LLW containers are stored in air-supported buildings on $150 \mathrm{ft}$ wide pads.

Of the stored mixed TRU and LLW at the TSA, approximately 95\% is assumed to be contaminated with chemically hazardous substances regulated under the RCRA, the State of Idaho's Hazardous Waste Management Act (HWMA), or the Toxic Substances Control Act (TSCA). RCRA and the State of Idaho HWMA govern the handling, treatment, and disposal of solid and hazardous materials and wastes. RCRA defines and identifies hazardous waste types and specifies how they must be transported, handled, and disposed of. Mixed wastes at the TSA include combustibles (e.g., rags, paper, and cloth); noncombustibles (e.g., metal, glass, and tilters); and absorbed or solidified process sludges (Clements 1982). TSCA regulates the storage waste containers contuminated with polychlorinated biphenyls (PCBs). Small amounts of PCBs are contained in approximately 7,000 drums. There are approximately 140,000 containers on the TSA pads.

Because retrievable storage of mixed TRU and LLW began in 1970 at the RWMC, some of the waste containers have been stored for over 20 years. There is no evidence based on TSA cell penetrations in 1978, 1979, and 1984 and diflerences between cell closure methods used at the TSA and the SDA Pad A, to indicate that any of the containers are breached or structurally unsound. However, for design purposes it has been assumed that up to $10 \%$ of the waste containers may be breached. All stored waste containers will be surveyed upon retrieval, and any breached containers will be overpacked in clean intact containers before transport to other RWMC facilities. Table 4 provides a current (1992) description of the chemicals and radioisotopes present in the waste. The description of the stored waste is based on Radioactive Waste Management Information System (RWMIS). The data contained in the RWMIS is based on manilest data provided by the originator of the waste. Approximately 17,000 waste containers stored on other TSA pads have been nondestructively assayed at the Stored Waste Examination Pilot Plant (SWEPP). In addition, 
Table 4. Radioactive waste inventory.

\begin{tabular}{|c|c|c|c|c|c|c|c|}
\hline \multirow[b]{2}{*}{ Waste typ: } & \multicolumn{2}{|c|}{ Volume } & \multirow[b]{2}{*}{$\begin{array}{l}\text { Radionuclide } \\
\text { distribution }\end{array}$} & \multicolumn{2}{|c|}{ Concentration } & \multicolumn{2}{|c|}{ Hazardous nonradioactive inventory } \\
\hline & $\left(m^{3}\right)$ & $\left(\mathrm{ft}^{3}\right)$ & & $\mathrm{Ci} / \mathrm{m}^{3}$ & $\mathrm{Ci} / \mathrm{tt}^{3}$ & Distribution & $\begin{array}{c}\text { Concentration } \\
\text { (ppm) }\end{array}$ \\
\hline \multirow[t]{7}{*}{$\begin{array}{l}\text { Stored } \mathrm{CH} \\
\text { TRU waste }\end{array}$} & $6.5 \mathrm{E}+0.4$ & $2.3 E+06$ & $50.4 \%$ Pu-241 & $3.2 \mathrm{E}+00$ & $8.9 \mathrm{E}-02$ & $\begin{array}{l}66.7 \% \text { Concentrated } \\
\text { Base - Solidified }\end{array}$ & $1.2 \mathrm{E}+03$ \\
\hline & & & $21.5 \%$ Am-214 & $1.3 \mathrm{E}+00$ & $3.8 \mathrm{E}-02$ & & \\
\hline & & & $15.5 \% \mathrm{Pu}-238$ & 9.7E-01 & 2.7E-02 & $\begin{array}{l}25.6 \% \text { Concentrated } \\
\text { Acid - Solidified }\end{array}$ & $4.6 \mathrm{E}+02$ \\
\hline & & & $9.9 \%$ Pu-329 & $6.2 \mathrm{E}-01$ & $1.7 \mathrm{E}-02$ & & \\
\hline & & & $2.2 \% \mathrm{Pu}-240$ & $1.4 \mathrm{E}-01$ & $3.9 \mathrm{E}-03$ & $7.8 \%$ Mercury & $1.4 \mathrm{E}+02$ \\
\hline & & & $2.0 \%$ U. 233 & $1.4 \mathrm{E}-02$ & $3.9 \mathrm{E}-04$ & & \\
\hline & & & $0.2 \% \mathrm{Cm}-244$ & $1.2 \mathrm{E}-02$ & $3.4 \mathrm{E}-04$ & & \\
\hline
\end{tabular}

sampling of some of these drums was performed to correlate assay data and manifest data. This assay and sampling program has provided confidence that the manifest data is a reasonab:y accurate description of the waste containers. The waste in the TSA areas are wastes that were shipped after 1970 and therefore contain more accurate records than some of the urlier received waste. 


\section{FACILITY DESIGN}

\subsection{General}

The RE project is to provide a weather enclosure over the earthen covered waste on TSA-1 TSA-2 pads and for the tarpaulin covered waste stored on TSA-R pad. The project is also to provide dedicated retrieval equipment. The enclosure is classified as a Radioactive Solid Waste Facility as defined in DOE Order 6430.1A.

The $\mathrm{RE}$ is a pre-engineered inetal building that is approximately $313,000 \mathrm{ft}^{2}$. The rominal size of the enclosure that extends over the TSA-R and TSA-1 pad areas is $200 \mathrm{ft}$ wide $\times 1,175 \mathrm{ft}$ long, with an average ceiling height of 30 to $35 \mathrm{ft}$. An adjacent $186 \times 420$ - $\mathrm{ft}$ appendage extends over the TSA-2 pad.

Two movable interior parallel walls (shrouds), approximately $200 \mathrm{ft}$ apart and perpendicular to the RE longitudinal exterior walls, provide a smaller, environmentally-conditioned work area for retrieval operations (see Figure 2). This retrieval work area encloses the earth overburden that has to be removed to expose the waste container stack face, the stacked containers that are to be removed, a hot staging area, an overpacking area, and a cold staging area. The two interior shrouds are periodically moved within the building as the waste containers are removed from the stack. The movable shrouds have seals around their perimeters that minimize air leakage from the remainder of the enclosure building to the work area.

Air ducts attached to the leading shroud, which bound the work area on the north, collect the air from the work area. This air is exhausted through a $>99 \%$ efficiency portable baghouse dust filter, and a single stage of $99.97 \%$ efficient HEPA filters. The discharged air passes through a heat exchanger before being exhausted through an emission stack. Airlocks are used to allow heavy equipment access to the retrieval work area.

EG\&G Idaho is responsible for managing the overall project activities for the DOE Idaho Field Office (DOE-ID). EG\&G Idaho is also providing the architectural engineering for the enclosure and enclosure systems and management of procurement activities for retrieval equipment and other Government-furnished equipment. The construction activities for the enclosure and subsystems will be managed by Morrison Knudsen-Ferguson of Idaho Company (MK-FIC). The completed facility will be managed by EG\&G Idaho, which is under contract to DOE-ID.

The construction of the enclosure and procurement of retrieval equipment will take approximately 28 months after the enclosure contract is awarded. 


\section{LEGEND}
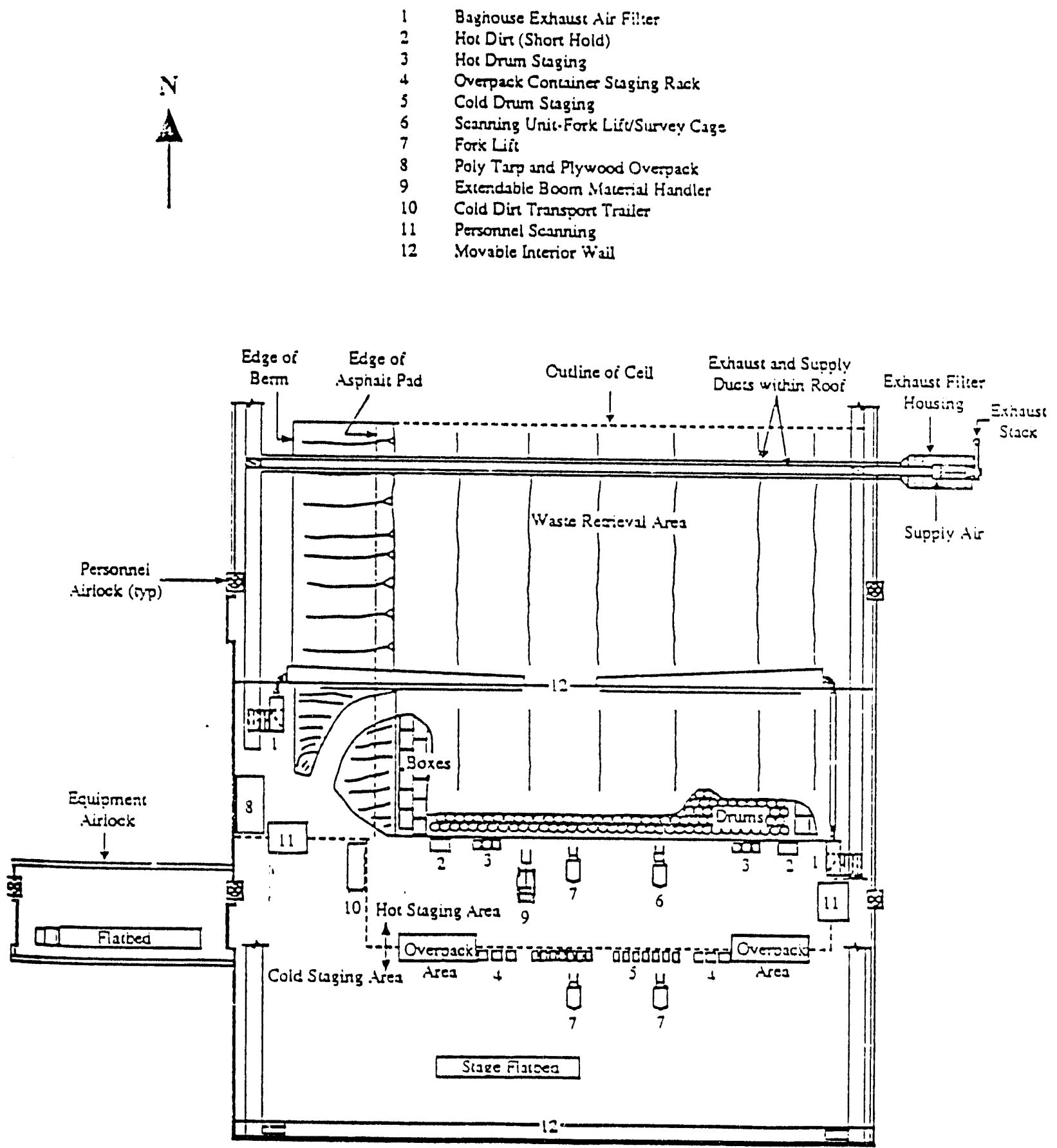

Figure 2. Diagram of the smaller work area in the RE. 


\subsection{Design Specifications}

The RE has been designed to the requirements of a Radioactive Solid Waste Facility per DOE Order 6430.1A Section 1324 (DOE 1989b). DOE Order 6430.1A imposes the requirements of UCRL 15910, which defines design and evaluation criteria for protection against natural phenomena hazards (i.e., seismic, extreme wind, and flooding). The goals of this guideline are to assure that DOE facilities are constructed to safely withstand the effects of natural phenomena without excessive conservatism and to provide uniformity between DOE facilities. The principle of this guideline is to identify structures and equipment that, if damaged, would result in a safety hazard to workers or a nonfunctional facility or the facility being replaced.

DOE Order 6430.1A gives general design criteria requirements. The DOE-ID Architectural Engineering (A-E) Standard (DOE 1992b) identifies specific architectural criteria for INEL facilities. The DOE-ID A-E Standard complies with and supplements the criteria of DOE Order $6430.1 \mathrm{~A}$. Guidance to resolve conflicts between the A-E Standard and DOE Order 6430.1A and to request waivers to the A-E Standard are given in the A-E Standard. In general, the A-E Standard takes precedence over minor conflicts. Major conflicts are resolved by DOE-ID. Waivers are approved by the DOE-ID Director of Engineering and Construction Management.

The current TSA-RE seismic design criteria are consistent with the current seismi design requirements in the DOE-ID A-E Standard.

There are no safety class systems, components, or structures within this facility as defined by DOE Order 6430.1A, Section 1300-2 (DOE 1989b). The RE building structural design meets the following design requirements:

- Seismic: Building structural components-UCRL 15910 Moderate Facility Use Category (i.e., dynamic analysis).

- Seismic: Remainder of the building components-UCRL 15910 Low Facility Use category with static analysis. This is functionally equivalent to the UBC Zone $2 b$, with an Importance Factor of 2.0.

- Snow: $30 \mathrm{lb} / \mathrm{ft}^{2}$.

- Wind: $80 \mathrm{mph}$, Exposure class $\mathrm{C}$.

- The foundation consists of concrete forms resting on caissons and footings which are anchored to bedrock.

\subsection{Code Compliance}

All codes and standards to which the RE has been designed are documented in Project Design Criteria for the TSA-RE project. 


\subsection{National Environmental Policy Act Compliance}

In order to comply with the National Environmental Policy Act (NEPA), an environmental assessment (EA) has been issued and addresses the impact to the environment by building and operating the RE. Environmental impacts documented in the EA still bound normal and off-normal operations of the RE. The stack parameters and ventilation requirements are bounded by both the EA and the State of Idaho air permit limitations. The Permit to Construct approved by the State of Idaho provides emission criteria.

Radiological emissions from routine operational activities presented in Section 7.4 and summarized in Section 2.1 were taken directly from the EA (DOE 1992a). Doses to workers and the public have been modeled using the CAP-88 computer code (Abbott 1990). Hazardous material emissions from routine operational activities presented in Section 7.4 and summarized in Section 2.2 were also taken directly from the EA. The radiological and hazardous material source terms remain consistent with the EA.

\subsection{Utilities}

\subsubsection{Retrieval Enclosure Ventilation}

The ventilation system controls provide only the shrouded work area with a controlled atmosphere and flnw pattern. The ventilation system will operate from $14,500 \mathrm{cfm}$ to approximately $48,000 \mathrm{cfm}$ to control carbon monoxide accumulation during the operation of diesel-powered equipment inside the building. The air supply side is designed for a maximum thow of $36,000 \mathrm{cfm}$ and includes an inlet filter, heat exchanger coil, heating system, evaporative cooling system, supply fan, and a distribution network that directs air to the trailing shroud supply registers.

All building ventilation is exhausted through a two-stage filtration system designed for a maximum of $48,000 \mathrm{cfm}$. The baghouse filter system removes dust, particulate, and smoke and is $>99 \%$ efficient. The final particulate filtration is provided by a single stage of HEPA filters ( $>99.97 \%$ efficiency). A variable speed exhaust fan is used to maintain the enclosure at a negative pressure with respect to atmosphere. The ventilation exhaust passes through a heat recovery heat exchanger and is directed to a stack that is approxir.ately $67.8 \mathrm{ft}$ high. A minimum of $10,000 \mathrm{cfm}$ will be exhausted during nonoperational hours to ensure safe occupancy.

\subsubsection{Radiation Monitoring}

Both interior and exhaust air is monitored for alpha and beta-gamma airborne contamination and radiation dose levels. Airborne concentrations of radioactive material are monitored using constant air monitors (CAMs). Radiation levels are monitored using remote area monitors. Local alarms are routed to the retrieval operations control station and provide warning to personnel located in the retrieval work area. Remote alarms will be provided to the Operations Control Building when it is constructed.

4.5.2.1 Interior Air Monitoring. Four CAMs are placed inside the enclosure to monitor airborne contamination. These are located in the following locations: 
- Next to the waste stack workface

- Near the trailing shroud

- In the exhaust air duct, upstream of the baghouse

- Ahead of the leading shroud (the portable CAM is in the retrieval building, but outside the shrouded area).

4.5.2.2 Exhaust Air Monitoring. The exhaust stack is monitored for alpha and beta-gamma contamination near the top of the exhaust stack using isokinetic air sampling techniques.

\subsubsection{Fire Protection}

Fire detection is accomplished using a linear cross beam system that detects the presence of smoke. When one beam detects smoke, it sends a signal to the Central Facilities Area (monitored 24 hours/day) and to local RWMC alarms. When an adjoining beam detects smoke, the fire protection system, which is normally dry, will be charged with water. Fire detection is also provided with a battery back-up if electrical power is lost. A trouble signal is sent to a staffed station when the system is powered by batteries or if the system fails for some other reason.

The fire protection system is a preaction dry pipe sprinkler system designed in accordance with the National Fire Protection Association (NFPA) regulations, NFPA-13, and services the entire RE including the area outside the shrouded area. System water flow is detected by a water motor alarm gong and a water flow alarm switch. The underground fire protection system is designed in accordance with NFPA-24. Minimum riser water supply piping is 6 in. All sprinkler and other automatic fire suppression system components are Underwriters Laboratories (UL) or Factory Mutual (FM) approved lor this application. Manual pull boxes are located throughout the facility. All requirements of the Life Safety Code will be met. The accident analysis does not take credit for this system.

\subsubsection{Breathing Air}

An oil-free breathing air distribution system and breathing air compressor with capacity for 12 persons is provided. The system complies with American National Standards Institute Z88.2; Compressed Gas Association G-7.1; EG\&G Idaho Operating Procedure OP-168, "Evaluation of Breathing Air Systems"; and 29 Code of Federal Regulations 1910.134. Breathing air manifolds are located along the entire length of the building. The breathing air compressor is capable of yearround operation by providing preheating of air for winter operations. Moisture separators are used to remove condensed moisture from the compressed air stream and air purification filters remove common contaminants. Backup air storage cylinders contain emergency breathing air capacity in the event of compressor failure.

The breathing air inlet is located approximately $28 \mathrm{ft}$ above the ground to minimize the potential from intaking emissions from trucks and other vehicles in the area. The intake is approximately $120 \mathrm{ft}$ downwind of the continuously monitored exhaust stack for the enclosure. The exhaust stack 
is approximately $65 \mathrm{ft}$ above the ground, and with the stack velocities present, no contamination is expected to reach the breathing air intake.

The Breathing Air System (BAS) is to be used only in specilic off-normal events where levels of contamination and/or hazardous elements dictate the use of personnel protection equipment requiring external air supply for long time periods. Before the start of cleanup, the facility would first be stabilized and brought back online-meaning all life safety systems are functioning normally including the ventilation system with the monitored and HEPA filtered exhaust stack. If an entry to the RE becomes necessary in order to begin recovery of the facility, self-contained breathing apparatus gear, such as Scott Air Packs, would be employed. Because of the baghouse and HEPA filters, particulate emission is of little concern. Therefore, only volatile organic compounds (VOCs) contained in the waste can be considered as a potential hazard. Considering the short-term evaporative nature of VOCs, the small average quantity residing in each waste container, and the delay of bringing the facility back online, the volume and velocity of air through the exhaust stack reduces the VOC concern to an extremely low level.

To alleviate the concern of the BAS taking in vehicle exhaust emissions, administrative control is activated through the TSA-RE Emergency Response Plan, prohibiting vehicular traffic, including waste container transport vehicles, from the BAS intake area. Administrative controls remain in effect until the off-normal event is rectified, cleanup is complete, and the facility can be operated in a safe, standard manner.

\subsubsection{Support Systems}

Utilities include the $120,480 / 277$, and $4160 \mathrm{~V}$ electrical distribution systems; the standby power system; the lighting system; the instrument air system; the telephone/voice paging system; the closed circuit television surveillance system; and the data acquisition system. The RE building provides change rooms, toilets, utilities, communication equipment, emergency response equipment, and a personnel contamination survey area.

\subsubsection{Decontamination}

Special features and controls have been incorporated into the design of the enclosure to minimize the potential for contaminating personnel, equipment, and the building during retrieval operations. First, building interior surfaces will be constructed of materials that have been selected for their decontamination properties. In addition, most piping, ventilation duct, etc., is being placed behind bulkheads to minimize the number of surfaces that can become contaminated. Third, the work area wili normally operate under a negative pressure, and airllows are in a direction from noncontaminated to potentially contaminated.

CAMs will also be used to detect the presence of contamination at the earliest possible time so that operations generating the contamination can be stopped. In addition, administrative controls will be in place during operation to assay soils and waste containers before they are removed. If contamination is detected, special operations will be put in place to maximize confinement of this contamination. A feature being included as part of the retrieval equipment is an isolation unit used for isolating contaminated or otherwise unsafe eontainers from the rest of the building. Within this unit, waste containers can be safely stabilized, decontaminated, and/or overpacked. 


\section{PROCESS SYSTEMS}

The procedure previously presented in the SWEPP SAR is basically the same as that being proposed for operation of the RE, except that the retrieval operations will be accomplished within an enclosure.

Various types of process equipment are used to remove overburden, examine and handle waste containers, and transport the various types of waste containers to the WSF. This equipment is being provided with state-of-the-art features to minimize operator stress, increase productivity, remove the operator from associated hazards, and minimize the chance for operator error. Process system changes through September 1990 have been incorporated in a conceptual retrieval process. A fully developed retrieval process will be presented in the FSAR.

\subsection{Overburden Removal Equipment}

The final soil overburden/sideburden sampling program will be an integral part of the stored waste container retrieval operation as part of the TSA-RE Operations and Maintenance Manual (O\&MM). Soil overburden/sideburden sampling will be conduct in two phases: (1) field screening and (2) laboratory analysis. The sampling activity will be conducted far enough in advance of the container retrieval stage of the operation to allow adequate time for laboratory analysis. Also, to reduce turnaround time, analyses will only be conducted for the known contaminate residing in the waste stack -selected VOCs, PCBs, heavy metals, and radionuclides. Phase 1, field screening (EPA Analytical Level II), will consist of collecting samples for analysis of soil vapor headspace using a field unit gas chromatograph. While in the field, all samples will immediately be surveyed for radiological contamination using a Ludium $2 \mathrm{~A}$ for gamma activity and a Ludlum 61 for alpha particles. Smears taken on all equipment contacting the samples will be surveyed for total activity with a NMC DS33 proportional counter converter. An $\mathrm{HNu}$ photoionization meter will be employed to investigate each sample location (borehole) for volatile organic vapors. Results of the gas chromatograph analysis and the other field data will be used to select locations from which to collect samples for laboratory analysis. Phase 2, laboratory analysis, will perform both radiological (gamma spectroscopy) and chemical analysis (EPA SW-846 methods) to detection levels not obtainable with present-day field equipment.

Early use of data from both phases of the sampling activity will allow better management of the disposition of the soil before releasing it from the enclosure.

The remaining overburden inside the RE will be removed by a track-mounted, electric motorpowered, front shovel configured excavator. The excavator is equipped with a bottom dump bucket; drum handlers for 30-, 55-, and 83-gal drums; forklift attachments; and other appropriate end effectors to retrieve all waste containers.

Two vacuum systems are used to remove dirt from between the waste containers after bulk overburden is removed by the excavator. The units are electric motor-powered. Radioactive soil is removed by a vacuum system dedicated to radioactive soil collection. This system is capable of storing the collected soil for disposition in sealed drums. 


\subsection{Waste Handling Equipment}

Battery-powered electric forklifts and the excavator will be used to relocate waste containers from the waste stack to the floor of the enclosure. When cargo containers are encountered on the TSA-R pad, Cell 1, a special movable $25 \times 25$-ft cargo container work platform will be used to remove the waste drums from the upper layer of cargo containers (stacked two high inside the cargo containers). The platform will be designed to withstand a loading commensurate with the waste containers and equipment on the platiorm. The waste drums inside the cargo containers will be removed and brought to the edge of the platform by an electric forklift. The drums will then be lowered to awaiting transport trucks using the excavator.

An isolation unit will be used when areas of contamination are detected at the waste stack face or a situation develops that can create an airborne contamination problem. Contaminated dirt removal and/or required container decontamination will be conducted inside the isolation unit to minimize the spread of contamination. The isolation unit has a volume of approximately 5,000 to $6,000 \mathrm{ft}^{3}$ and will provide approximately $4,000 \mathrm{ctm}$ of ventilation air that will be filtered through a single HEPA filter before being exhausted onto the top of the waste stack and being collected by the enclosure exhaust system.

\subsection{Waste Transport Equipment}

The waste containers ready for transport to the WSF will be loaded by forklift or excavator onto a flatbed trailer located inside the RE. The beds are $48 \mathrm{ft}$ long $\times 8.5 \mathrm{ft}$ wide. When the flatbed trailer is filled with containers, a semi-tractor will 'se used to pull the loaded trailer out through the equipment airlock and transport the containets to the WSF. Each trailer will be smeared for contamination before leaving the RE. The semi-tractors will be diesel-powered. 


\section{WASTE CONFINEMENT AND MANAGEMENT}

Breached and damaged containers, as well as surface-contaminated containers not easily decontaminated, will be overpacked into clean, intact containers. Contaminated cloth, plastic, or wood that is encountered will be covered and removed in the most manageable form possible. Contamination will be fixed with tape or other covering before moving any plastic, plywood, or timbers. Contaminated plywood or timbers will undergo size reduction before packaging in clean overpack containers. Size reduction techniques will be addressed in the FSAR.

Surface-contaminated containers will be decontaminated using standard wiping procedures. The waste generated as a result of decontaminating surface-contaminated containers will be packaged and handled as LLW or mixed-LLW. Waste materials assaying $>100 \mathrm{nCi} / \mathrm{g}$ will be handled as mixed TRU wastes. Contaminated clothing and other materials used by workers that are not easily decontaminated will be packaged into clean, intact waste containers. After waste materials are packaged and ready for transler out of the RE, the waste will be handled as described in Section 5.3.

The RE firewater drainage system is designed for control and collection of liquid runoff by channeling the liquid through a series of trenches to liquid sumps. These sumps are of sufficient capacity to collect the design basis runoff from tïe sprinkler water and can be decontaminated. Firewater collected by this system will be pumped into a portable tank and transported to an appropriate facility for treatment and disposal.

Expended lubricants and other chemicals will be checked for contamination before removal from the RE and will be disposed of in an appropriate manner. Any hazardous constituents regulated under RCRA, HWMA, or TSCA will be stored or disposed of appropriately. The sanitary wastes generated by the facility will be disposed in a designated landfill. 


\section{HAZARDS PROTECTION}

The following subsections describe the hazards associated with working within the TSA RE. These were systematically identified from the list of hazards identified in EG\&G (1988). Table 2 identifies all of the categories of hazards considered in the evaluation. Industrial hazards will be developed and included in the FSAR after the procedures and equipment have been finalized. The concern for radiological and chemical hazard protection has resulted in plans for various administrative controls, prevented measures, and monitoring capability.

The RWMC, which includes the TSA, is considered a Treatment, Storage, and Disposal (TSD) Site. EPA and Ozcupational Safety and Health Administration (OSHA) directives require a health and safety (H\&S) plan for all TSD sites. This Health and Safety Plan has been developed and addresses the following major areas: Personnel Training; Hazards Evaluation; Work Control Zones and site entry procedures; environmental monitoring and record keeping; decontamination procedures; emergency procedures; health and safety procedures; health and safety responsibilities; and administrative and organizational control. A brief discussion of each of the above topics is provided below.

The TSA waste is classified as $\mathrm{CH}$; therefore, routine retrieval operation is basically a hands-on process, aided by dedicated retricval equipment (c.g., forklifts, excavator, and vacuum system). To achieve maximum efficiency, the work area will maintain an environment that allows the use of only the basic personnel protective equipment (e.g., safety shoes and glasses, gloves, coveralls, hard hat, and hearing protection). A respirator (for both chemical and radioactive matcrial protection) will be carried by each worker to be used in the event of an off-normal event. To maintain this work environment, constant monitoring and sampling for the known contaminants of the waste stack will take place in advance of the retrieval and at the immediate work area. Work area sampling and monitoring will be conducted for both chemical and radioactive contaminants similar to sampling and monitoring conducted during the preretrieval process. Interstitial soil samples will immediately be surveyed for radiological contamination using Ludlum $2 \mathrm{~A}$ for gamma activity and Ludlum 61 for alpha particles. Smears of equipment and waste containers will be surveyed for total activity with a NMC DS33 proportional counter converter. Vapor headspace analysis of selected interstitial soil samples sill be conducted using a field unit gas chromatograph. Laboratory chemical analysis (EPA SW-846 Methods) will be performed on selected samples to detection levels not obtainable with field equipment and for heavy metals. Constant monitoring and surveillance of the work area will be conducted by personnel and fixed equipment. Health physics, industrial hygienist, and safety engineers will constantly survey the work area for radiation/radioactive contamination, hazard materials, and physical hazards (e.g., noise levels and airborne dust). Hand held field instruments, such as Ludlum 14C, Eberline Ion Chamber RO3C, Ludlum 61 (radiations measurements), and $\mathrm{HNu}$ photoionization meters (organic vapors), will be supplemented by fixed remote area monitors (RAMs), both alpha and beta-gamma constant air monitors (CAMs), and Fourier transform infrared spectrometer (organic vapors). Personnel will be monitored using dosimetry, active and passive vapor monitors, and body temperature measurements. Results of the constant sampling, monitoring, and observation will determine the level of personnel protection equipment required to continue retrieval or decontaminate the work area. 


\subsection{High Voltage}

Distribution pancls P-TSA-1, EP-TSA-1, and P-TSA-2 are 480/277 V, three-phase, 60 cycle electrical panels. LP-TSA-1, ELP-TSA-1, ELP-TSA-3, and LP-TSA-3 are 120/208 V, three-phase, 60 cycle electrical distribution pancls. Two $5-\mathrm{kV}$ fused medium voltage load interrupter switches feed $4,160 \mathrm{~V}$ to the excavator. ELP-TSA-3 is provided with standby power. A shock hazard exists when working with the breakers, disconnects, or electrical panels.

All materials, labor, equipment, and workmanship conforms with the applicable chapters of the National Electrical Code and the National Electrical Safety Code. All electrical equipment complies with UL or FM standards and is UL listed or FM approved. Only trained maintenance electricians are allowed to conduct maintenance or repairs.

\subsection{Flammable Gases, Liquids, and Dusts}

Some of the waste containers may contain an explosive concentration of hydrogen in oxygen caused by radiolytic decomposition of the waste. Methane gas buildup in a waste drum is bounded by the hydrogen explosion (significantly smaller quantities are generated).

Extremely small quantities of tlammable liquids exist within the waste containers (i.e., butyl and methyl alcohol). The quantities present are small enough that they do not create a fire hazard from a breached container or a spill greater than that associated with ordinary combustible material. Hazards associated with handling these containers are bounded by the hydrogen gas scenario.

The diesel-powered equipment used within the RE is equipped with fuel tanks, and the potential exists for a fuel spill. Hazards associated with these flammable liquids are the same as the hazards associated with operating motor vehicles. In addition, refueling this equipment will not take place within the RE.

Fugitive silicone dust is considered a potential hazard within the RE. Large quantities of dirt must be removed to expose the waste containers. The ventilation system is designed to supply air from the back of the shrouded area to the stack face. This will minimize the amount of suspended dust in the retrieval work area. Additional dust suppression measures, including mists, may be used should additional fugitive dust control be necessary. This will be determined after initial retrieval operations have commenced.

\subsection{Effects of Chemical Exposures}

Hazardous constituents of the waste are assumed to be those identified in Gratson (1990). Hazardous chemicals that may become airborne present the primary hazard to operations personnel. The possible major contributors to airborne hazards are expected to include trichloromethane, carbon tetrachloride, trichloro-trifluoroethane, trichloroethylene, perchloroethylene, methylene chloride, methyl alcohol, butyl alcohol, and xylene.

Other hazardous materials, such as mercury, lead, cadmium, beryllium, lithium, nitric acid, and nitrates, will not become airborne under normal conditions. Any PCBs present in the waste are 
expected to exist in solidified form. Organic liquid wastes, including PCBs, were solidified in calcium silicate before packaging. PCBs would not become airborne readily because they have been solidified, they are contained in multiple layers of plastic packaging material, and they exhibit a low vapor pressure.

Additional toxic air pollutants, as defined by the Idaho Air Quality Bureau, that may be present in the mixed TRU and LLW include aluminum, aluminum oxide, asphalt fumes, copper, magnesium oxide, oxalic acid, sodium hydroxide, sulfuric acid, zirconium, and oil. With the exception of solidified oil, these chemicals are estimated to contribute a negligible fraction $(<0.00009 \%)$ to the total amount of hazardous/toxic chemicals in the TSA waste. Oil is present in sludge waste, and the percentage of total waste weight that oil makes up is estimated to be $3.4 \%$ (Gratson 1990). Oil will not become airborne under normal operations of the RE.

Because of the low calculated release rates of hazardous materials from the small percentage of waste drums that are expected to be breached (estimated to be $10 \%$ of all waste containers), the expected airborne concentrations are low enough to present no health hazard to workers in the enclosure or to the public. Table 1 summarizes the average annual chemical concentrations expected from routine operations of the RE. Peak concentrations for normally expected container breaches are bounded by the drop box accident. Monitoring and related procedures will be in place to ensure guidelines are not exceeded.

Although exposure of workers to chemical hazards is expected to be low, monitoring for contaminates will be performed during the retrieval operation. In addition, workers will have readily available, on their person, half-face respirators for use during up-set conditions.

\subsection{Radioactive Materials}

The mixed TRU and mixed LLW to be retrieved contain an external radiation dose hazard. Should the container become breached, an internal inhalation hazard will also exist. Personnel conducting retrieval operations will be in general proximity of waste containers during many phases of the retrieval operation. Radiation fields will be in a constant state of flux as waste containers are removed from the face of the waste stack.

\subsubsection{External Radiation Hazards}

By definition, $\mathrm{CH}$ mixed TRU and LLW containers must exhi')it a surface dose rate of $<200 \mathrm{mrem} / \mathrm{hr}$. Greater than $90 \%$ of the waste containers exhibit a surlace dose rate $<10 \mathrm{mrem} / \mathrm{hr}$. Health physics technicians will be present during all waste operation:. Containers will be vacuumed and wiped as necessary to remove soil and debris and will be surveysed for alpha and beta-gamma radiation. Radiation monitors with alarm systems are located an the enclosure work area to warn personnel if high radiation fields exist.

In 1989, 106 badged RWMC workers received a measured 4,209 mrem (over 12 months) for an average EDE of $39.7 \mathrm{mrem} /$ worker (range 0 to $251 \mathrm{mrem}$ ) (DOE 1992a). This annual average dose is typical of those received by RWMC workers over the last few years and is not expected to increase appreciably during retrieval operations. 


\subsubsection{Internal Radiation Hazards}

Air emissions of radioactive materials from the RE may occur during retrieval operations because of breached waste containers. Portions of the waste containers are nearing the end of their planned, 20-year storage life, and some may be breached because of environmental conditions within the waste stack. Several selected retrievals have occurred in the past, however, with no evidence that waste containers were breached because of their storage conditions. In fact, the containers were found to be in excellent condition.

Although little evidence exists that containers are in unsound condition, the RE is designed so that removal of waste containers can be conducted in a safe manner even if some of them are found to be breached. First, the normal retricval operation has been designed to minimize the number of personnel needed on the waste stack. This serves to minimize the number of personnel subjected to internal radiation hazards during an abnormal condition. Second, the enclosure ventilation system will maintain the work area at a negative pressure relative to outside and with respect to other a. eas within the enclosure. This minimizes the potential for contamination spreading to other parts of the building and to other areas of the TSA. Third, air flow within the work area is designed to flow from the trailing shroud to the forward shroud. This creates an airflow pattern that moves in the direction of highest expected contamination levels. Fourth, the breathing zone will be monitored near the retrieval site to measure the presence of radiological contaminates. If any are detected, personnel protective equipment (PPE) may be donned. In addition an isolation unit may be placed over the suspected breached container which further isolates the container from the work area. The Isolation Unit is provided with a breathing air system to give maximum protection to workers stabilizing a breached container. Fifth, all containers are cleaned and surveyed for radiological contamination before they are removed and as soon as the surfaces of the containers are exposed.

7.4.2.1 Average Source Term. A source term of $0.16 \mathrm{Ci} / \mathrm{tt}^{3}$ is used in this safety analysis report for drums and liberglass reinforeed plywood (FRP) boxes. This is equivalent to $1.176 \mathrm{Ci}$ per 55-gal drum and $17.9 \mathrm{Ci}$ for the FRP boxes. The average source term was determined using the Radioactive Waste Management Information System (RWMIS) database and the ORIGEN2 computer code (RSIC 1985). An RWMIS data sort was performed on the shipment date. The individual radionuclide inventory in each shipment during a given year was summed for all shipments received by the RWMC during that year. This was then input into ORIGEN2 and decayed for 1 year to account for decay and ingrowth of daughter products. The radionuclide inventory for shipments received during the next year was then added to the total and decayed 1 more year.

The database assessment shows live isotopes contribute to very nearly $100 \%$ of the current (decayed) activity of the TSA waste. These live isotopes are Pu-238, Pu-239, Pu-240, Pu-241, and Am-241. Figure 3 stows the estimated gram loading distribution of fissile material in waste containers. This distribution is for gram loading; however, if a distribution for curies was available, it would be similar in shape. Note that $85 \%$ of the waste containers within the waste stack have less then the average activity used for this safety analysis report.

The average source term accounts for all waste shipped to the RWMC from 1971 through December 1988. The total was then decayed 3 additional years, through 1991, and this value $(362,400 \mathrm{Ci})$ was used as the total radionuclide inventory for stored waste (Litteer 1989) volume of 


\begin{tabular}{|c|c|c|c|}
\hline $\begin{array}{l}\text { Number } \\
\text { of drums }\end{array}$ & $\begin{array}{l}\% \text { of } \\
\text { drums }\end{array}$ & $\begin{array}{l}\text { Total } \\
\text { loading } \\
\text { grams }\end{array}$ & $\begin{array}{l}\text { Average } \\
\text { loading } \\
\text { grams }\end{array}$ \\
\hline 51951 & $50 \%$ & 6234.12 & 0.12 \\
\hline 27807 & $27 \%$ & 34480.68 & 124 \\
\hline 8096 & $8 \%$ & 33679.36 & 4.16 \\
\hline $5=68$ & $\Xi \%$ & 43541.76 & 7.32 \\
\hline 3715 & $4 \%$ & 54610.50 & 14.70 \\
\hline 2727 & $3 \%$ & 79437.51 & 29.13 \\
\hline 1501 & $1 \%$ & 78877.55 & $\$ 2.55$ \\
\hline 675 & $1 \%$ & 61168,50 & 90.52 \\
\hline 650 & $1 \%$ & 108075.50 & $16 \overline{2} 27$ \\
\hline 102690 & & $: 00105.50$ & \\
\hline
\end{tabular}

Average drum loading 4.87

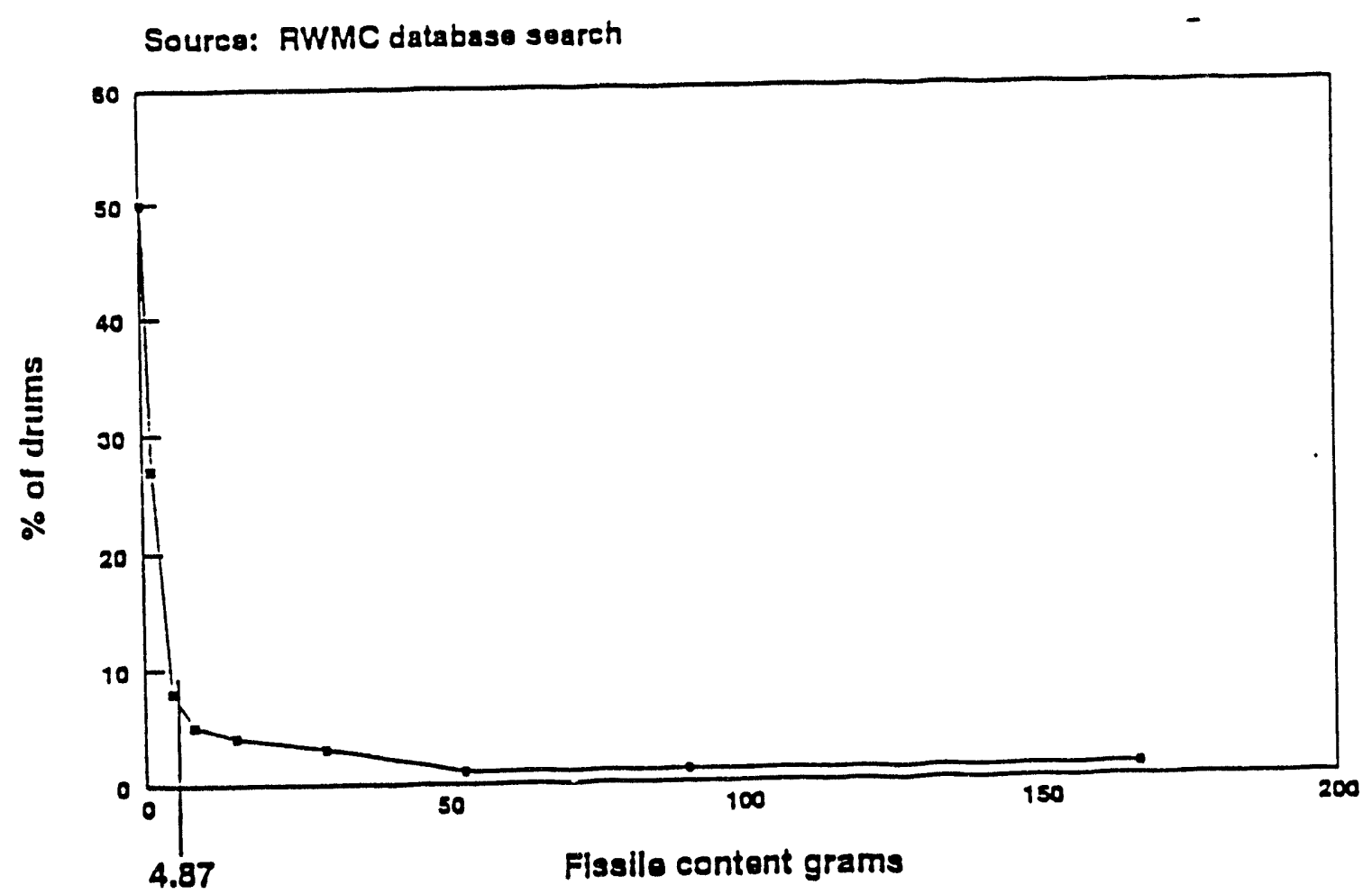

Figure 3. Distribution of grams of fissile material in waste containers. 
waste was $2.3 \mathrm{E}+06 \mathrm{ft}^{3}$ (Davis 1989). The average source term was then defined in terms of an activity per unit volume:

average source term $=\frac{362,400 \mathrm{Ci}}{2,259,256 \mathrm{ft}^{3}}=0.16 \mathrm{Ci} / \mathrm{ft}^{3}$.

7.4.2.2 Routine Releases. The waste was assumed to contain $0.16 \mathrm{Ci} / \mathrm{ft}^{3}$, and $1 \%$ of the radionuclide content of the waste was assumed to be released from the breached drums (DOE 1992a). A resuspension factor of 1.0E-04 was assumed (DOE 1992a). The source term for routine radiological emissions from the $\mathrm{RE}$ is provided in Table 5. The releases were calculated as follows:

release $=N C \times .1 \times I P \times V C \times 0.16 \times .01 \times 1.0 E-04 \times 1.0 E-05$

where

$$
\begin{aligned}
& \text { NC }=\text { number of drums per year }=20,000 \\
& .1=\text { fraction of drums breached (DOE 1992a) } \\
& \text { IP } \quad=\text { fraction of source term for a particular isotope }=\text { see Table } 5 \\
& \text { VC }=\text { volume per drum }=7.33 \mathrm{ft}^{3} \\
& 0.16=\text { average source term }=0.16 \mathrm{Ci} / \mathrm{ft}^{3} \\
& .01=\text { fraction spilled from the breached drum } \\
& 1.0 \mathrm{E}-04=\text { resuspension factor (includes respirable fraction) } \\
& \text { 1.0E-05 = decontamination factor (considers baghouse, and HEPA filtration). }
\end{aligned}
$$

It was assumed that $90 \%$ of the waste containers will be retrieved intact and that no air emissions will result from intact containers. It was assumed that $10 \%$ of the containers will be breached, based on TSA cell penetrations in 1978, 1979, and 1984, and differences between cell closure methods used at the TSA and the SDA Pad A.

7.4.2.3 Dose Calculations from Routine Releases. Radiological doses from normal releases of radionuclides from the RE were determined using CAP-88 (Abbott 1990). CEDEs were determined for the maximum individual located at $100 \mathrm{~m}$, at the Experimental Breeder Reactor No. 1 (EBR-I) $(2,900 \mathrm{~m})$, and at the INEL boundary $(6,000 \mathrm{~m})$ where the maximum radionuclide air concentrations were determined to occur. The CEDEs were calculated using DOE dose conversion factors. Five-year (1981 to 1985) frequency meteorological data collected from the RWMC meteorological tower at the $10-\mathrm{m}$ level were used to model atmospheric dispersion. In addition, the CEDE received by the population within $80 \mathrm{~km}$ of the RWMC was determined using 1989 population data. The CEDEs for the maximum individuals and population are shown in Table 6 (Abbott 1990). 
Table 5. Radionuclide releases because of normal operations of the RE.

\begin{tabular}{lll}
\hline Radionuclide & $\begin{array}{c}\text { Release } \\
(\mathrm{Ci} / \mathrm{yr})\end{array}$ & IP $^{\mathrm{a}}$ \\
\hline $\mathrm{Pu}-238$ & $3.87 \mathrm{E}-09$ & $1.65 \mathrm{E}-01$ \\
$\mathrm{Pu}-239$ & $2.54 \mathrm{E}-09$ & $1.08 \mathrm{E}-01$ \\
$\mathrm{Pu}-240$ & $5.84 \mathrm{E}-10$ & $2.49 \mathrm{E}-02$ \\
$\mathrm{Pu}-241$ & $1.00 \mathrm{E}-08$ & $4.26 \mathrm{E}-01$ \\
$\mathrm{Pu}-242$ & $4.60 \mathrm{E}-14$ & $1.96 \mathrm{E}-06$ \\
$\mathrm{Am}-241$ & $6.00 \mathrm{E}-09$ & $2.55 \mathrm{E}-01$
\end{tabular}

a. Fraction of source term for a particular isotope.

Table 6. Calculated dose consequences of routine releases from the RE (Abbott 1990).

\begin{tabular}{lcc}
\hline \multicolumn{1}{c}{ Receptor } & CEDE & $\begin{array}{c}\text { Allowable } \\
\text { dose }\end{array}$ \\
\hline Worker at $100 \mathrm{~m}(\mathrm{mrem} / \mathrm{yr})$ & $2.0 \mathrm{E}-06$ & $5.0 \mathrm{E}+03$ \\
Public at EBR-I $(2,900 \mathrm{~m})(\mathrm{mrem} / \mathrm{yr})$ & $2.4 \mathrm{E}-07$ & $5.0 \mathrm{E}+02$ \\
Public at maximum Site & & \\
$\quad$ boundary $(6,000 \mathrm{~m})(\mathrm{mrem} / \mathrm{yr})$ & $3.2 \mathrm{E}-07$ & $5.0 \mathrm{E}+02$ \\
Population within $80 \mathrm{~km}(\mathrm{person}-\mathrm{rem} / \mathrm{yr})$ & $2.1 \mathrm{E}-07$ & $\mathrm{NA}$ \\
\hline
\end{tabular}


The CEDE of 3.2E-07 mrem/yr at the maximum Site boundary falls well below $1 \%$ of the $10 \mathrm{mrem} / \mathrm{yr}$ National Emission Standards for Hazardous Air Pollutants recently promulgated by EPA (54 FR 51654) (EPA 1989).

The Committee on Biological Effects of Ionizing Radiation (BEIR) of the National Academy of Sciences has published a detailed revicw of available data on radiation-induced health effects (BEIR IV 1980). This report uses a variety of data and accepted methods to quantify the health impacts of low levels of radiation.

The BEIR report estimates of health risks associated with radiation exposure were used to quantify the possible changes in radiation-induced health effects that might be caused by the operation of the Special Isotope Separation facility proposed to be located at the INEL (DOE 1988). The same health effects estimators are used here because the radionuclides involved are the same. Although the 1988 BEIR report has been issued, its focus is on health effects from radon. It was determined that the calculated number of health effects from TRU nuclides using BEIR IV (1980) will be less than those calculated using DOE (1988). Small adjustments in the risk estimates associated with the recently issued 1989 BEIR report, which has been reviewed by DOE and the scientitic community, will not change the conclusions in this report.

The health effects estimator for high-linear energy transfer radiation was determined to be 280 cancer fatalities per million person-rem (DOE 1988). Health effects estimators are derived from population data such as those from survivors of atomic bomb blasts in World War II. Therefore, the health effects reported here are calculated using only the $80-\mathrm{km}$ population dose. The excess numbers of latent cancer fatalities expected in the exposed population for a dose of 2.1E-07 person-rem will be $5.88 \mathrm{E}-11$ or 0 .

\subsection{Nuclear Criticality}

Refer to Section 8.2 .4 for the discussion on nuclear criticality.

\subsection{High Noise Levels}

Various pieces of machinery and waste handling equipment, including material handlers, semi-tractors, ventilation fans, and air compressors, produce high noise levels when in use. All process equipment has been designed to minimize the amount of noise generated where possible (e.g., mufflers, run time, and shiclding). Periodic noise surveys will be conducted during operational activities to identify noise levels. Appropriate mitigative measures will then be taken (e.g., personnel will be supplied with hearing protection) to control the levels to within the allowable range.

\subsection{Toxic and Noxious Emissions}

The ventilation system has been designed to control carbon monoxide accumulation during operation of diesel-powered equipment inside the building. The only normai anticipated activity involving combustion equipment would be the operation of a diesel tractor pulling in a trailer to be loaded. Design calculations for the ventilation system indicate that there is sufficient air to dilute carbon monoxide below the required threshold limit. Portable monitors will be used to monitor 
carbon monoxide levels and engine running time of the diesel tractor within the RE will be minimized.

\subsection{Mechanical and Moving Equipment Dangers}

Waste material handling equipment, such as the forklifts, excavator, materials handler, and the dump trailers, are items of possible danger. Operational procedures will be developed before operations that will administratively control personnel movement within the RE. In addition, only trained operators will be allowed to operate the material handling equipment. Training will be conducted as identified in Section 6.2 of the RWMC SAR (EG\&G 1986). Movable equipment is equipped with audible reverse gear alarms that warn local personnel when equipment is moving in reverse. All equipment is being designed using human factors enginecring. For example, retrieval equipment (such as the excavator and mobile vacuum system) are being designed to be fail safe, standard labeling and control systems will be used, control cabs and consoles will be sized to be usable by $90 \%$ of the population, collision avoidance systems will be used, and other features will be used to reduce operator stress. All equipment meets OSHA requirements.

\subsection{Inadequate Ventilation}

Because operation of diesel-powered waste handling and waste transport equipment is required inside the RE and there are airhorne radioactive material concerns, hazards could exist from inadequate ventilation. The ventilation system is designed to furnish a minimum ventilation rate to control accumulation of radioactive material or products of combustion during the retrieval operations inside the building (nominally 14,500 to $40,000 \mathrm{cfm}$ ). Loss of power to the ventilation system will necessitate an immediate halt to all operational activities. Standby power will exhaust $10,000 \mathrm{cfm}$ to maintain the work area at a negative pressure.

\subsection{Working at Heights}

Because of the layered waste storage at the TSA, personnel will be required to work at heights during the waste retrieval operation. Overburden may need to be removed from around waste containers. Containers at the stack face must be surveyed before movement. Cargo containers will be unpacked onto a platform before lowering to the ground.

Many waste container operations will be conducted with waste handling equipment designed to be operated from the RE tloor. To comply with OSHA regulations, required platforms will make extensive use of side rails in order to provide personnel maximum protection while working at heights. Overall, the retrieval equipment and process are being designed to minimize the need for operators and technicians to work on the waste stack face.

\subsection{Material Handling Dangers}

The waste is stored in a variety of container types including 30-, 55-, and 83-gal drums; plywood boxes; metal M-III bins; SAND boxes; and fiberglass reinforced plywood boxes. These waste containers were stacked into cells with the perimeter of each cell consisting of boxes to provide stability to a cell containing drums. Drums were stacked in horizontal and vertical arrays. Drums 
are stacked to approximately $16 \mathrm{ft}$ high. For vertically arranged drums, the drums are stacked five high. Except for the south end of TSA-R pad, the waste containers were covered by plywood, fabric, and 2 to $4 \mathrm{ft}$ of soil. The south end of TSA-R is covered with fabric only.

Based upon the expected condition of the containers as evidenced by selected retrievals in the past and the stacking arrangement, the waste stack is expected to be stable during the retrieval operations. Analysis presented in Butler (1991) also predicts stability of waste containers during seismic activity.

In addition, the extent of the material handling hazard is limited due to the nature of the retrieval operations and the equipment being procured to handle the waste containers. The amount of waste exposed at any one time will be limited. Overburden removal will be limited to approximately $9 \mathrm{ft}$ based upon limitations of the excavator. This reach capability will also allow for retrieving containers in a stair step manner, if needed. Material handlers will also be provided with improved hydraulic systems to reduce operator stress and to provide precision movement of end effectors. This will avoid unnecessary contact with other containers, thus, minimizing the potential for toppling or penetrating the waste containers. Equipment operated in close proximity to the waste stack will also be provided with collision avoidance systems for the same reason. The number of handling and transfer operations has also been minimized. For a typical container, one handling operation is required to move the container from the stack to a transler vehicle. As indicated earlier, the operation also has been designed to minimize the number of personnel needed near the waste stack. Retrieval stack configuration knowledge will be incorporated into future operating procedures.

During retrieval operations, the average waste stack working face arrangement will be a stair-step configuration, rising away from the work area into the waste stack. Retrieval operations are to proceed cell by cell-south to north. Only during an initial cell penetration will the retrieval face arrangement be a vertical wall of boxes ( 4 high).

Emphasis is also being placed on providing adequate lighting and minimizing other industrial hygiene hazards such as noise. This work environment will also contribute to minimizing material handling dangers.

\subsection{Temperature Extremes}

The climate of Southeastern Idaho presents wide temperature extremes that must be accounted for when year-round operations are expected. Personnel must be provided comfortable working conditions in order to minimize the occurrence of operationally-related accidents. The manual nature of the retrieval process requires the presence of personnel in the work space at all times during retrieval operations. This requirement makes the environmental working conditions important for safety.

The RE ventilation system is designed to provide sufficient heating and cooling to support year-round operations. The ventilation supply equipment includes a external propane heating unit and an evaporative cooler. The ventilation supply uses an air-to-air heat exchanger that transfers heat from the exhaust side. The RE movable shrouds, with their intlatable seals, reduce the interior air volume that must be conditioned. Loss of the ventilation system or weather conditions that result 
in temperatures in excess of the allowable ranges will require the retrieval operations to be discontinued.

\subsection{Inadequate Illumination}

The potential does not exist for inadequate illumination during retrieval operations. Seventy foot-candles of illumination have been installed in the operational area of the RE. During a loss of power, this lighting will no longer be available and all operational activities will cease. Emergency exit lighting is provided by battery packs to allow orderly personnel evacuation from the RE. 


\section{ACCIDENT SAFETY ANALYSIS}

The following subsections evaluate the potential major accident scenarios that are expected from abnormal operations or postulated accidents initiated from operation of the RE.

The probability of occurrence of a wide spectrum of (1) handling, (2) fire initiated, and (3) natural phenomena initiated accidents are covered by a separately contracted study (Ebasco 1990; Ebasco 1991). Probabilities are based on a combination of information presented in the RWMC SAR, other references applicable to INEL and RWMC experiences, and engineering judgement. While this study summarizes the bases for the majority of the assumptions made in the analyses presented below, and all have a basis in fact, bounding calculations are nevertheless provided (Section 8.4) to place the importance of these assumptions into perspective. Where the probability of accident occurrences cannot be shown to be negligible or where conservative bounding calculations do not demonstrate acceptable risk, commitments are made to either refine these calculations and/or provide additional mitigation measures.

An additional category of analyses provided in this PSAR are those associated with construction. Since the Retrieval Enclosure is constructed over an existing TRU storage area, attention must be paid to the possibility of construction activities disrupting the existing wastes with resulting releases of radioactive or hazardous materials. These postulated accidents are covered in Section 8.3. They are no longer applicable once the RE is completed, and Section 8.3 will not appear in the FSAR.

\subsection{Natural Phenomena}

The impacts associated with natural phenomena accident scenarios for the RE are bounded by the analyses presented in the RWMC SAR (EG\&G 1986) for existing RWMC facilities. Specific RE operations are taken into account in the evaluation of each natural phenomena accident sequence. These events are summarized in Table 7 (EG\&G 1986, Ebasco 1991).

Table 7. Natural phenomena accident scenarios presented in the RWMC SAR (EG\&G 1986).

\begin{tabular}{lc}
\hline \multicolumn{1}{c}{ Event } & $\begin{array}{c}\text { Probability } \\
(\text { event/yr })\end{array}$ \\
Volcano & $4 \mathrm{E}-09$ \\
Earthquake & $5 \mathrm{E}-04$ \\
Tornado & $1 \mathrm{E}-07$ \\
High winds $(50<\mathrm{mph}<80)$ & $5 \mathrm{E}-01^{\mathrm{a}}$ \\
Flooding & $4 \mathrm{E}-05$ \\
Meteorite impact & $<1 \mathrm{E}-06$ \\
Lightning strike & 1 strike/mi ${ }^{2}$-yr \\
& \\
a. Based on number of thunderstorms and associated high winds per year. Maximum instantaneous \\
wind speed was 78 mph.
\end{tabular}




\subsubsection{Volcano}

The estimated base probability for volcanic activity at the RWMC location is below the credibility limit for DOE operations $(<1.0 \mathrm{E}-06$ event/yr). Retrieval activities inside the RE will not increase this probability and, therefore, this event is not analyzed further. The 660 - square mile Arco-Big Southern Butte area, in which the RE is located, includes the Arco Volcanic Rift Zone. Refer to the RWMC SAR (EG\&G 1986) for more information on potential consequences related to volcanic activity near the RWMC. Lava flow from postulated activities in the Arco Rift Zone is not expected to reach the RWMC. Ash fall, while credible could not exceed the effects of design snow load; ventilation clogging would not be a concern since all activities would be terminated.

\subsubsection{Earthquake}

Several off-normal events may be caused by earthquakes: toppling of waste containers, damage to the enclosure, and damage to utility systems such as the propane supply system.

During an earthquake, waste container boxes may topple from the stack. It is presumed that the boxes falling from a height greater than $6 \mathrm{ft}$ could rupture (Lindsay and Downing 1972). Drums could also topple during an earthquake. Drums are required by 49 CFR 178.350 to pass a 4 -ft drop test. Test results confirming this compliance are found in DOE (1987). Limited testing at RWMC (EG\&G 1986) has indicated 55-gal drums will survive a 12-ft drop, the drop expected by the top container when the drums are stacked five high.

Collapse of the enclosure onto the exposed waste stack is also a potential hazard. Because of potential exposure to the public and workers during this event, the enclosure is being designed to meet UCRL-15910 moderate use criteria.

All propane tanks that are potential lire initiators to the RE will be scismically qualified to a UCRL-15910 moderate facility use category (1.0E-04 frequency earthquake). Other possible modifications to the propane tanks will be addressed in the FSAR.

Two different intensity earthquakes were evaluated for the RE. The first event involves an earthquake strong enough to topple waste containers in the RE but not strong enough to cause significant building structural damage. It was assumed that such a toppling earthquake would be of a magnitude greater than the design requirements for the nonstructural components of the RE, which is UBC Zone $2 \mathrm{~b}$ with an Impcrtance Factor of 2.0. This earthquake has an assumed probability of 5.0E-04 event/yr (Ebasco 1991).

The second scenario evaluated was for an earthquake strong enough to cause structural damage to the RE. It was assumed that the structural beams could fall and land on top of and breach uncovered waste containers. The probability of this earthquake is assumed to be 1.0E-04 (Ebasco 1991). During both earthquakes, the ventilation system is assumed to fail, resulting in an unfiltered release to the environment.

Earthquake scenarios involving toppling waste drums that are assumed to explode upon impact with the ground are analyzed in Section 8.2.2.2. Fires resulting from drum explosions are bounded by the maximum credible fire (MCF) presented in Section 8.2.1.1. 
8.1.2.1 Box Toppling without RE Structural Damage. The assumption is made that the entire stack face is comprised of $4 \times 4 \times 7$-ft FRP boxes stacked four high, and that fifty percent of the top row (10 boxes) and 10\% of the second row ( 2 boxes) are assumed to be breached in the event (total of 12 boxes breached). Ten percent of the waste is assumed to be spilled into the room and available for resuspension. A release fraction of $1 \mathrm{E}-04$ (includes amount respirable as well as resuspended) is assumed for release outside the RE (see Section 4.8 of DOE 1992a). The amount of radioactive material assumed to be released is calculated to be $2.2 \mathrm{E}-03 \mathrm{Ci}$.

$$
2.2 E-03 C i=12 \text { boxes } \times \frac{112 f^{3}}{b o x} \times \frac{0.16 C i}{f t^{3}} \times 1 E-04 \times 0.1
$$

The hazardous chemicals involved in this release are bounded by the airborne releases presented in Tables 8 and 9 for an earthquake with structural damage involving 22 waste boxes.

8.1.2.2 Box Toppling with RE Structural Damage. In addition to the amount of material released from the previous analysis, it is assumed that an additional 10 waste boxes are breached by a falling beam (there is a probability of $3.1 \mathrm{E}-01$ that a beam lands on exposed waste boxes) (Ebasco 1991). The overall probability of this event is decreased to be 3.1E-05 event/yr (e.g., 1.0E-04 $\times 3.1 \mathrm{E}-01)$. The amount of radioactive material assumed to be released is calculated to be $3.9 \mathrm{E}-03 \mathrm{Ci}$.

$$
3.9 E-03 C i=22 \text { boxes } \times \frac{112 f t^{3}}{b 0 x} \times \frac{0.16 C i}{f^{3}} \times 1 E-04 \times 0.1
$$

The hazardous chemicals involved in this release are presented in Tables 8 and 9. Perchloroethylene, butyl alcohol, methyl alcohol, and xylene were not considered because they contribute negligible fractions to the total VOC inventory.

The assumption was made that every container has an average concentration of VOCs within its entire volume. This is very conservative because only the head space gases will be available for immediate release; the remainder of the container volume is filled with waste materials (Clements and Kudera 1985).

The inclusion of the metals in the release source term is conservative because they are generally in monolithic forms that are unavailable for airborne particulate release. Hazardous constituents of the waste that were not considered to become airborne and, thus, were not considered include mercury, lithium, nitric acid, nitrates, and PCBs. 
Table 8. Average container headspace concentrations and airborne releases for volatile organic compounds for a structural earthquake scenario.

\begin{tabular}{lcl}
\hline $\begin{array}{l}\text { Volatile organic } \\
\text { compound }\end{array}$ & $\begin{array}{c}\text { Average } \\
\text { concentration } \\
(\mathrm{g} / \mathrm{L})\end{array}$ & $\begin{array}{c}\text { Airborne } \\
\text { release } \\
(\mathrm{g})^{\mathrm{b}}\end{array}$ \\
\hline $\begin{array}{l}\text { Carbon tetrachloride } \\
\text { Methylene chloride }\end{array}$ & $1.9 \mathrm{E}-03$ & $1.33 \mathrm{E}+02$ \\
$1,1,1$-trichloromethane & $5.0 \mathrm{E}-04$ & $3.49 \mathrm{E}+01$ \\
$1,1,2$-trichloro- & $1.3 \mathrm{E}-02$ & $9.07 \mathrm{E}+02$ \\
$1,2,2$-trifluoroethane & $1.2 \mathrm{E}-03$ & $8.37 \mathrm{E}+01$ \\
Trichloroethylene & $7.0 \mathrm{E}-04$ & $4.88 \mathrm{E}+01$ \\
& & \\
& & \\
a. Data obtained from Clements and Kudera (1985). & \\
&
\end{tabular}

Table 9. Average airborne particulate releases for a structural earthquake.

\begin{tabular}{lcc}
\hline Chemical & $\begin{array}{c}\text { Source term } \\
(\mathrm{g})^{\mathrm{a}}\end{array}$ & $\begin{array}{c}\text { Airborne release } \\
(\mathrm{g})^{\mathrm{b}}\end{array}$ \\
\hline Lead & $1.82 \mathrm{E}+04$ & $4.00 \mathrm{E}-00$ \\
Cadmium & $6.62 \mathrm{E}+00$ & $1.46 \mathrm{E}-03$ \\
Beryllium $^{\mathrm{c}}$ & $4.63 \mathrm{E}+02$ & $1.02 \mathrm{E}-01$ \\
Asbestos $^{\mathrm{c}}$ & $3.02 \mathrm{E}+03$ & $6.64 \mathrm{E}-01$ \\
& & \\
a. Average mass of chemical constituents in a waste box. & \\
b. Based on 22 boxes each spilling 10\% with a release fraction of 1.0E-04 (DOE 1992a). \\
c. Assumes that 50\% of the waste asbestos is friable (DOE 1992a).
\end{tabular}




\subsubsection{Tornado}

The base probability of this event is considered to be below the credibility limit for DOE operations (EG\&G 1986). Nevertheless, the radiological or hazardous waste release effects of a tornado would be unlikely to exceed those of the structural earthquake discussed in the preceding section or the high winds discussed in the following section.

\subsubsection{High Winds}

High winds will not affect the structure of the RE. The wind load on the building has been determined using an $80 \mathrm{mph}$ wind and calculated according to the UBC exposure $C$ methodology. Extremely high winds may damage the building skin, but they are not expected to cause a release of hazardous or radioactive materials greater than that postulated for box toppling events. In this event, operations will cease until the building had been repaired. Section 5.4.4 of the RWMC SAR contains additional information on high winds (EG\&G 1986).

Wind generated missiles could be generated. The most probable damaging missile is a $15 \mathrm{lb}$, $2 \times 4$-in. timber plank, typically found in the construction of office trailers, storage sheds, or other light timber structures. This missile is assumed to penetrate the RE skin with sulficient energy to also strike and penetrate a waste drum or box. The results of this event are bounded by the dropped box scenario presented in Section 8.2.3.

\subsubsection{Flooding}

The mechanisms for a flood at the RWMC can be broken into two events: (1) localized runoff from the surrounding terrain and (2) localized runoff within the TSA. The extensive flood protection system for the RWMC is discussed in Chapter 2.0.

Localized runoff within the TSA has been addressed by contouring the area and providing adequate pathways for water to egress. If some water did enter the RE, the results could be small amounts of contamination within the building. The liquid collection system, which provides a series of sumps inside the building, will prevent the majority of water from reaching the waste containers. Even in the event of flooding within the RE, airborne releases of radioactive or hazardous materials generated as a result of water contacting the waste containers will be very small. Some release to soil could, in fact, occur; however, to prevent such occurrences is one of the reasons that the RE is being constructed and the impacted waste being moved.

\subsubsection{Meteorite Impact}

The base probability of a meteorite impact is below the credibility limit for DOE operations $(<1.0 \mathrm{E}-06$ event/yr). Even if a meteorite strike were postulated it would probably be less damaging than the earthquake with RE structural damage analyzed in Section 8.1.2.2.

\subsubsection{Lightning}

The expected number of lightning strikes at the INEL is one per square mile per year (EG\&G 1986). The RE has lightning protection. Nevertheless, assuming such a strike were to occur, 
the largest release of radioactive or hazardous materials will occur from a lightning-induced fire within the RE. Section 8.2.1 contains a description of this accident.

\subsection{Operational Accidents}

The impacts associated with operational accident scenarios for the TSA RE are presented in this section and summarized in Table 10.

\subsubsection{Fires}

Radiological material releases can occur from a number of postulated fires, primarily to the 566 plywood boxes stored on TSA-1 pad, Cell 2. Fire initiating mechanism and their estimated probabilities of occurrence are summarized in Table 11.

8.2.1.1 Maximum Credible Fire (MCF) Scenario Description. A spectrum of fires can be assumed; however, all are a subset of the MCF. The assumed MCF occurs when 75 uncoated plywood boxes are exposed to air on TSA-1 pad, Cell 2. During off-hours, a fire is initiated by one of the events listed in Table 10. The fire starts at one end of the box stack and propagates along the row of boxes. The sprinkler system fails and because the Emergency Fire Brigade is not present during off-hours, the Central Facilities Fire Department must respond.

The fire is assumed to burn for 2 hours after fire initiation, but it continues to release contaminants to the atmosphere for another 10 hours. It is assumed that half the contaminants are released during the first 2 hours, and the remainder are released in the following 10 hours. Because of the heat of the fire, plume rise is calculated to occur for the first 2 hours. Ambient temperature is assumed for the remaining release duration, so the plume does not rise for the last 10 hours. The dispersion calculations use moderately stable (Class F) conditions and windspeeds of $0.5 \mathrm{~m} / \mathrm{sec}$ within $2 \mathrm{~km}$ and $2.0 \mathrm{~m} / \mathrm{sec}$ at locations greater than $2 \mathrm{~km}$ away (Ebasco 1990).

The fire protection system (e.g., sprinklers) fails, but the fire detection system works. The plywood boxes will propagate a fire (Brown 1979). Based on these results, it is assumed that boxes from one end to half the distance across the stack face and . $p$ to the second level of the stack will be burned and breached; 19 boxes will be breached before the fire department responds (Ebasco 1990). 
Table 10. Operational accident scenarios.

Event

Probability

(event/yr)

Fires initiators $^{c}$

Lightning fire

3.0E-04

Electrical panel fire

3.8E-06

Vehicle fire

6.9E-04

Vehicle fuel leak

$1.6 \mathrm{E}-04$

Earthquake induced fire

2.0E-05

Desert fire

2.9E-07

Explosions

Dropped waste drum

5.3E-03

Earthquake induced drum explosion

3.0E-06

Localized hydrogen accumulation

Incredible ${ }^{\mathrm{a}}$

Spills

Dropped box in RE

6.0E-03

Dropped box outside

$1.2 \mathrm{E}-02$

Criticality

30-gal drum storage

Incredible $\mathrm{a}^{\mathrm{a}}$

Firewater actuation

Incredible $\mathrm{a}^{\mathrm{a}}$

Aircraft impact

Incredible ${ }^{\mathrm{a}}$

Loss of electric power

Anticipated $^{\mathrm{b}}$

Industrial safety

Anticipated $^{b}$

a. An incredible event has a probability $<1.0 \mathrm{E}-06$ event/yr.

b. An anticipated event has a probability $>1.0 \mathrm{E}-02$ event/yr.

c. Fire initiators such as smoking, trash container fires, etc. will be addressed through administrative controls and associated procedures. 
Table 11. Frequency of tire initiators in the RE (Ebasco 1990).

\begin{tabular}{lcc}
\hline \multicolumn{1}{c}{ Fire initiator } & $\begin{array}{c}\text { Fire probability } \\
\text { (event/yr) }\end{array}$ & $\begin{array}{c}\text { Probability of } \\
\text { fire involving } \\
\text { stored waste }\end{array}$ \\
\hline Lightning fire & $1.0 \mathrm{E}-01$ & $3.0 \mathrm{E}-04$ \\
Electric panel fire & $1.3 \mathrm{E}-03$ & $3.8 \mathrm{E}-06$ \\
Vehicle fire & $8.3 \mathrm{E}-04$ & $6.9 \mathrm{E}-04$ \\
Vehicle fuel leak fire & $1.6 \mathrm{E}-04$ & $1.6 \mathrm{E}-04$ \\
Earthquake fire & $2.0 \mathrm{E}-05$ & $2.0 \mathrm{E}-05$ \\
Desert fire & $2.9 \mathrm{E}-02$ & $2.9 \mathrm{E}-07$ \\
\hline a. Fire initiators such as smoking, trash containers fires,etc. will be addressed through \\
administrative controls and associated procedures.
\end{tabular}

As added conservatism, the heat from the burning boxes is assumed to cause over-pressurization of the bottom four rows of steel drums immediately adjacent to the burning boxes (a total of 72 drums). All the combustible materials in these drums are assumed to ignite and burn. The resulting smoke is so dense that the ventilation and filtration system becomes plugged and is completely ineffective. The airlock system is also violated. All airborne material is assumed released unfiltered.

The probability of this fire scenario is estimated by combining the probability of the most likely fire initiator involving waste that could occur during off-hours (e.g., lightning fire, $P=3.0 \mathrm{E}-04$ ) (Ebasco 1991) with the probability that the sprinkler system fails $(P=1.0 E-02)$ (Davis and Satterwhite 1989). Thus, the estimated scenario probability is $3.0 \mathrm{E}-06$ event/yr.

8.2.1.1.1 Radiological Release-A database sort was pertormed to refine the source term for the wooden boxes stored on cell 2 of the TSA-1 pad. The best information available shows 552 (112 $\mathrm{ft}^{3}$ each) wooden boxes containing a total of $766 \mathrm{~g}$ of weapons grade Rocky Flats Plant plutonium. This information was input into the ORIGEN2 computer code to account for decay and ingrowth of the inventory of these boxes from December 31, 1971, to December 31, 1991 (Riedesel 1991a).

The source term for the drums is based on the 1971 stored radionuclide inventory including decay and ingrowth from 1971 to 1991 (Riedesel 1991b). This method assumes an equal distribution of radiological material in the waste per unit volume. Conservatism results from the large number of drums assumed to be involved in the fire.

The release fractions applied have been divided into two parts based on the combustibility of the material. Based on typical drum content descriptions, $25 \%$ of the waste content is considered to be combustible (Ebasco 1990). Ten percent of the combustibles are considered to be aerosolized based upon experimental observations involving the combustion of radiological contaminated combustibles (Mishima and Schwendiman 1972). A 1\% aerosolization factor was applied to the noncombustibles. This factor is based upon the results of experiments involving gasoline fueled fires on contaminated stainless steel surlaces (Mishima and Schwendiman 1972). Ebasco (1990) discusses the basis for both of these values in more detail. 
The total atmospheric radiological release for the MCF scenario at the TSA-RE is $3.36 \mathrm{E}-01 \mathrm{Ci}$ (Ebasco 1990). Because the fire is postulated to occur after working hours, no personnel are exposed inside the building. However, a worker is assumed to be located $100 \mathrm{~m}$ away. The member of the public is assumed to be located $6 \mathrm{~km}$ away at the nearest INEL boundary and is exposed to the full 12 hour release.

Consequences were evaluated for a worker located $100 \mathrm{~m}$ from the TSA-RE during the MCF scenario (McCormack 1992). Exposure was evaluated using two cases; (1) moderately stable meteorological conditions (Class F) for the entire 12 hour release duration and (2) neutral meteorological conditions (Class D) for the last 10 hours of the release duration, during which no plume rise occurs with moderately stable conditions only for the first 2 hours (including plume rise). For the second case, exposure was evaluated for all receptors for comparison. Neutral conditions were considered for the longer duration second phase of the release because stable conditions are typically short-lived and may not persist for the full 12-hour release.

Radiological doses were computed using the RSAC-4 computer code (Wenzel 1990). For the first case, moderately stable conditions, the total EDE to the worker at $100 \mathrm{~m}$ was computed to be $2.8 \mathrm{E}+01 \mathrm{rem}$, all of which is attributed to the last 10 hours of the release. For the second case, neutral stability conditions during the last 10 hours of the release, the total EDE to the worker at $100 \mathrm{~m}$ was computed to be $2.4 \mathrm{E}+01$. Although the results reflect a slight decrease in calculated dose that is attrioutable to the different stability class, the $100-\mathrm{m}$ location is close enough to the release point that the calculated increase in vertical mixing is small. The doses to individuals are presented in Table 12.

Secretary of Energy Notice (SEN-35-91) establishes two safety goals that are designed as aiming points for performance. They are

1. The risk to an average individual in the vicinity of a DOE nuclear facility for prompt fatalities that might result from accidents should not exceed one-tenth of one percent $(0.1 \%)$ of the sum of prompt fatalities resulting from other accidents to which members

Table 12. CEDEs resulting from the RE MCF.

\begin{tabular}{lcccc}
\hline Pathway & $\begin{array}{c}\text { Public dose } \\
6,000 \mathrm{~m} \\
(\mathrm{rem})\end{array}$ & $\begin{array}{c}\text { Allowable } \\
\text { public dose } \\
(\text { rem })\end{array}$ & $\begin{array}{c}\text { Worker dose } \\
100 \mathrm{~m} \\
(\mathrm{rem})\end{array}$ & $\begin{array}{c}\text { Allowable } \\
\text { worker dose } \\
\text { (rem) }\end{array}$ \\
\hline Inhalation & $5.1 \mathrm{E}-02$ & - & $2.8 \mathrm{E}+01$ & - \\
Ingestion & $3.4 \mathrm{E}-01$ & - & $\mathrm{NA}$ & - \\
Ground surface & $1.7 \mathrm{E}-06$ & - & $9.2 \mathrm{E}-04$ & - \\
Air immersion & $2.4 \mathrm{E}-09$ & - & $1.3 \mathrm{E}-06$ & - \\
Total & $3.9 \mathrm{E}-01$ & $0.5 \mathrm{E}+00$ & $2.8 \mathrm{E}+01$ & $5.0 \mathrm{E}+00$ \\
\hline
\end{tabular}


of the population are generally exposed. For evaluation purposes, individuals are assumed to be located within 1 mile of the site boundary.

2. The risk to the population in the area of a DOE nuclear facility for cancer fatalities that might result from operations should not exceed one-tenth of one percent $(0.1 \%)$ of the sum of all cancer fatality risks resulting from all other causes. For evaluation purposes, individuals are assumed to be located within 10 miles of the site boundary.

The accident scenario spectrum for the TSA-RE does not result in any prompt fatalities, and based on the cancer fatalities per million person-rem presented in Section 7.4.2.3, no cancer fatalities will result.

8.2.1.1.2 Hazardous Release-The estimated hazardous material releases from the MCF at the RE are presented in Table 13. The source term was estimated by the product of the average weight fraction of total waste for each hazardous constituent from Clements 1982 and the weight of waste involved in the fire. Based on the best TSA-1 pad, Cells 1 and 2 content code and container type information available it was concluded that containers involved in the fire do not contain organic compounds or PCBs ( e.g., no content code 3 waste in plywood containers). The aerosolization factors assumed were 1.0E-02 for metals and asbestos, 1.0E-01 for nitrates and nitric acid, and 1.0 for cadmium (Ebasco 1990). These values were used to compute release rates for each chemical for the first 2 hours and the last 10 hours of the release.

Table 14 lists time-weighted average (TWA) threshold limit value (TLV) air concentrations for the workers by summing the product of each air concentration multiplied by the time of exposure at that concentration and dividing this sum by the total 12-hour exposure duration. The computed TWA air concentrations are then compared with the applicable short-term exposure limit (STEL) TLVs. The TLVs are for worker safety but are also used as guidance for public exposures in lieu of firm DOE guidance.

To determine whether additive effects of chemical air concentrations are significant, a total HI was computed for each receptor. These values were calculated from the sum of the ratios of chemical air concentrations to their applicable TLVs. If the total HI is greater than unity, additive effects are compared to immediately dangerous to life or health (IDLH) levels. The HIs for the worker and member of the public were calculated to be $4.1 \mathrm{E}+00$ and $9.2 \mathrm{E}-03$, respectively.

The 100-m data presented in Tables 13 and 14 are the result of supplementary analysis done by Ebasco (McCormack 1992). The total HI using TLVs for $100 \mathrm{~m}$ is 4.1 . Because this total HI was greater than 1, the time weighted average air concentration at $100 \mathrm{~m}$ was compared to immediately dangerous to life or health (IDLH) levels. These levels have been developed to define concentrations of materials from which workers could and should evacuate within 30 minutes without escape-impairing symptoms or any irreversible health effects and were developed by the National Institute for Occupational Safety and Health for industrial application. These values can be found in Table 14. Asbestos does not have a value identified. When the time weighted air concentrations at $100 \mathrm{~m}$ were compared to these values (chemical concentration divided by IDLH), the resulting sum is $5.4 \mathrm{E}-03$. Therefore, the chemical hazard is not significant by this standard. 
Table 13. Hazardous constituent release rates from the RE MCF.

\begin{tabular}{|c|c|c|c|c|c|c|c|}
\hline \multirow[b]{2}{*}{$\begin{array}{l}\text { Hazardous } \\
\text { Constituent }\end{array}$} & \multirow[b]{2}{*}{$\begin{array}{l}\text { Quantity } \\
\text { released } \\
\text { (lb) }\end{array}$} & \multirow[b]{2}{*}{$\begin{array}{l}\text { Quantity } \\
\text { released } \\
(\mathbf{m g})\end{array}$} & \multicolumn{2}{|c|}{ 1st 2 hours } & \multicolumn{3}{|c|}{ Last 10 hours } \\
\hline & & & $\begin{array}{c}\text { Release } \\
\text { rate } \\
(\mathrm{mg} / \mathrm{sec})\end{array}$ & $\begin{array}{l}\text { Air conc } \\
6 \mathrm{~km} \\
\left(\mathrm{mg} / \mathrm{m}^{3}\right)\end{array}$ & $\begin{array}{c}\text { Release } \\
\text { rate } \\
(\mathrm{mg} / \mathrm{sec})\end{array}$ & $\begin{array}{l}\text { Air conc } \\
100 \mathrm{~m} \\
\left(\mathrm{mg} / \mathrm{m}^{3}\right)\end{array}$ & $\begin{array}{c}\text { Air conc } \\
6 \mathrm{~km} \\
\left(\mathrm{mg} / \mathrm{m}^{3}\right)\end{array}$ \\
\hline Cadmium & $8.49 E-02$ & $3.85 E+04$ & 2.67E- -00 & $4.08 \mathrm{E}-06$ & S.35E-01 & $4.54 \mathrm{E}-03$ & $9.36 \mathrm{E}-06$ \\
\hline Lead & $2.34 E+00$ & $1.06 \mathrm{E}+06$ & $7.37 E+01$ & $1.13 \mathrm{E}-04$ & $1.47 \mathrm{E}+01$ & $1.25 \mathrm{E}-01$ & $2.58 E-04$ \\
\hline Mercury & $1.00 \mathrm{E}+00$ & $4.54 \mathrm{E}+05$ & $3.15 E+01$ & $4.81 \mathrm{E}-05$ & $6.30 E+00$ & 5.35E-02 & $1.10 \mathrm{E}-04$ \\
\hline Lithium & $5.01 E-01$ & $2.27 \mathrm{E}+0 \mathrm{~S}$ & $1.58 \mathrm{E}+01$ & $2.41 \mathrm{E}-0 \mathrm{~S}$ & $3.16 E+00$ & $2.68 \mathrm{E}-02$ & $5.52 \mathrm{E}-05$ \\
\hline Beryllium & $5.94 \mathrm{E}-02$ & $2.69 E+04$ & $1.87 \mathrm{E}+00$ & $2.86 \mathrm{E}-06$ & $3.74 \mathrm{E}-01$ & $3.18 \mathrm{E}-03$ & $6.55 \mathrm{E}-06$ \\
\hline Nitric acid & $5.38 \mathrm{E}+00$ & $2.44 E+06$ & $1.69 \mathrm{E}+02$ & $2.59 \mathrm{E}-04$ & $3.39 E+01$ & $2.88 \mathrm{E}-01$ & $5.93 \mathrm{E}-04$ \\
\hline Nitrates & $1.05 \mathrm{E}+00$ & $4.76 E+05$ & $3.31 E+01$ & 5.05E-05 & $6.61 E+\infty 0$ & $5.61 \mathrm{E}-02$ & $1.16 \mathrm{E}-04$ \\
\hline Asbestos & 7.75E-01 & $3.52 \mathrm{E}+05$ & $2.44 \mathrm{E}+01$ & 3.73E-05 & $4.88 \mathrm{E}+00$ & 4.14E-02 & $8.54 \mathrm{E}-05$ \\
\hline
\end{tabular}

Table 14. Hazardous constituent concentrations from the RE MCF.

\begin{tabular}{|c|c|c|c|c|c|c|c|c|}
\hline \multirow[b]{2}{*}{$\begin{array}{l}\text { Hazardous } \\
\text { constituents }\end{array}$} & \multicolumn{2}{|c|}{ Time weighted average } & \multicolumn{2}{|c|}{ Applicable TLVs } & \multicolumn{2}{|c|}{ Hazard indices ${ }^{a}$} & \multirow[b]{2}{*}{$\begin{array}{c}\text { IDLH } \\
\left(\mathrm{mg} / \mathrm{m}^{3}\right)\end{array}$} & \multirow[b]{2}{*}{$\begin{array}{l}\text { Conc } \\
\mathrm{IDLH}^{b}\end{array}$} \\
\hline & $\begin{array}{c}\text { Air conc } \\
6 \mathrm{~km} \\
\left(\mathrm{mg} / \mathrm{m}^{3}\right)\end{array}$ & $\begin{array}{l}\text { Air conc } \\
100 \mathrm{~m} \\
\left(\mathrm{mg} / \mathrm{m}^{3}\right)\end{array}$ & $\begin{array}{l}\text { STEL-TLV } \\
\left(\mathrm{mg} / \mathrm{m}^{3}\right)\end{array}$ & $\begin{array}{l}\text { TWA.TLV } \\
\left(\mathrm{mg} / \mathrm{m}^{3}\right)\end{array}$ & $\begin{array}{l}\text { Offsite } \\
6 \mathrm{~km}\end{array}$ & $\begin{array}{l}\text { Onsite } \\
100 \mathrm{~m}\end{array}$ & & \\
\hline Cadmium & $8.48 \mathrm{E}-06$ & $3.78 E-03$ & - & $5.00 \mathrm{E}-02$ & $1.70 \mathrm{E}-04$ & $7.57 \mathrm{E}-02$ & 50 & $7.6 \mathrm{E}-05$ \\
\hline Lead & $2.34 \mathrm{E}-04$ & $1.04 \mathrm{E}-01$ & - & $1.50 \mathrm{E}-01$ & $1.56 \mathrm{E}-03$ & $6.95 \mathrm{E}-01$ & 700 & $1.5 \mathrm{E}-04$ \\
\hline Mercury & $9.99 \mathrm{E}-05$ & $4.46 \mathrm{E}-02$ & - & $5.00 \mathrm{E}-02$ & $2.00 \mathrm{E}-03$ & $8.91 \mathrm{E} \cdot 01$ & 28 & $1.6 \mathrm{E}-03$ \\
\hline Lithium & $5.00 \mathrm{E}-0.5$ & $2.23 \mathrm{E}-02$ & - & $2.50 \mathrm{E} \cdot 02$ & $2.00 \mathrm{E}-03$ & 8.93E-01 & 55 & $2.2 \mathrm{E}-03$ \\
\hline Beryllium & $5.93 \mathrm{E} \cdot 06$ & $2.65 \mathrm{E}-03$ & - & $2.00 \mathrm{E}-03$ & $2.97 \mathrm{E}-03$ & $1.32 \mathrm{E}+00$ & 10 & $2.7 \mathrm{E}-04$ \\
\hline Nitric acid & $5.37 \mathrm{E}-04$ & $2.40 \mathrm{E}-01$ & $1.00 \mathrm{E}+01$ & $5.20 \mathrm{E}+00$ & $1.03 \mathrm{E}-04$ & $2.40 \mathrm{E}-02$ & 262 & $9.2 \mathrm{E}-04$ \\
\hline Nitrates & $1.05 \mathrm{E}-04$ & $4.68 \mathrm{E}-02$ & $1.00 \mathrm{E}+01$ & $5.20 \mathrm{E}+00$ & $2.02 \mathrm{E}-05$ & $4.68 \mathrm{E}-03$ & 262 & $1.8 \mathrm{E}-04$ \\
\hline Asbestos & $7.74 \mathrm{E}-05$ & $3.45 E-02$ & - & $2.00 \mathrm{E}-01$ & $3.87 \mathrm{E}-04$ & $1.73 \mathrm{E}-01$ & NA & NA \\
\hline Total & - & - & - & - & $9.20 \mathrm{E}-03$ & $4.08 \mathrm{E}+00$ & - & 5.4E-03 \\
\hline \multicolumn{9}{|c|}{ a. Hazard indices are determined by dividing the chemical concentration by the applicable TLV. } \\
\hline \multicolumn{9}{|c|}{ b. $\quad$ DLH $=$ immediately dangerous to life or health. } \\
\hline
\end{tabular}


8.2.1.2 Other RE Fire Scenarios. Several key assumptions were made in determining the MCF scenario. First, the fire had to involve combustible materials. The uncoated plywood boxes provide the largest source of this material. Drums, M-III bins, and SAND boxes are noncombustible. FRP boxes will burn but only after being exposed to a sustained flame for 40 minutes. This limited large fire to areas of TSA-1 pad, Cells 1 and 2. A lightning strike, electrical panel fire, or handling accidents are the most likely initiators.

A second key assumption is the ability to initially control the fire. The largest fire will occur when operational personnel are not working (e.g., evenings and weekends). The fire suppression system must fail in order for the fire to spread. Other fire scenarios, including handling accidents, the vehicle fire, and the vehicle fuel leak, would have to occur during normal working hours. Fire detection and response would curtail the fire spread, resulting in a much smaller fire.

A fire postulated to result from an earthquake should result in lesser consequences because the radioactive or hazardous material content of material available to fuel the fire is diminished. The base probability for a toppling earthquake with one or more drum explosions is estimated to be 3.0E-06 event/yr (Ebasco 1991).

The last initiator is an uncontrolled desert fire. Although such fires do occur at the INEL, the amount of combustible range material is limited and no such fire has ever damaged site facilities. The RWMC is surrounded by a flood control berm and ditch which should be more than adequate to stop a fire absent prior fire fighting actions. Inside the berm and ditch, standoff distances of at least $200 \mathrm{ft}$ preclude fire spreading to the RE (see Figure 1, site plan).

\subsubsection{Explosions}

Some of the waste drums stored at the TSA are likely to contain potentially explosive gases such as hydrogen and, possibly, methane. This combustion has been evaluated extensively in Section 5.3.3 of the RWMC SAR (EG\&G 1986). This section provides a summary of analysis of explosion scenarios that are relevant for operations in the RE.

8.2.2.1 Dropped Waste Drum. This scenario involves dropping a waste drum on a hard surface. The drum is assumed to contain an explosive gas and oxidizer, and the explosion is initiated by the impact of the drum on a hard surface. Given sufficient explosive gas content, it is possible in theory for a drum impact to generate sufficient internal heat energy to initiate an explosion. However, testing has shown that explosions are very difficult to initiate even under ideal conditions (EG\&G 1986). Several tests have been conducted using sparkers to attempt to initiate an explosion with extremely flammable concentrations of hydrogen in oxygen, and the drums failed to explode. Nevertheless, this mechanism is considered credible.

The probability of this explosion scenario occurring in the TSA-RE is estimated by combining the probability of a drum being breached during handling with the probability that the drum contains a flammable gas mixture that ignites. RWMC experience indicates that an accidental waste container drop or puncture occurs at a frequency of 1E-05 per handling operation. Based upon a 10,000 drum equivalent retrieval rate and assuming that for a conservative year 10,000 drums are retrieved, the probability of a drum being dropped is 
$\frac{1 E-05 \text { drops }}{\text { handling operations }} \times \frac{10,000 \text { drums }}{\text { year }}=.1$ events/yr .

It has also been estimated that $19 \%$ of the waste drums contain mixtures of hydrogen and oxygen (EG\&G 1986). Assuming that these drums will ignite if they are dropped or punctured, the probability of an explosion occurring is

$.1 \times 0.19=1.9 E-02 / y r$.

This accident is more energetic than the dropped box, however, the larger volume of box versus the drum and the fact that the worker would almost certainly evacuate rapidly can let us conclude that the worker dose for this accident will be bounded by the box spill.

If this explosion should occur the particulate will be filtered through a high efficiency bag house and HEPA filter before it was emitted from the enclosure. Therefore, dose to a co-located worker or the public would be insignificant. See Section 8.4 .4 for estimate of worker dose.

8.2.2.2 Earthquake-Induced Drum Explosion. This scenario analyzes both the nonstructural earthquake and the structural earthquake with respect to initiating one or more drum explosions. As discussed in Section 8.2.1.2, the nonstructural earthquake could lead to drums toppling from the stack and exploding upon contact with the floor. This could lead to a fire within the RE, but it is bounded by the MCF presented in Section 8.2.1.1. The probability of this event is estimated to be 3.0E-06 event/yr (Ebasco 1991).

The structural earthquake scenario considers a beam falling on waste drums in addition to having the same explosion potential from toppling drums described above. The impact of the roof of the RE collapsing on the waste drums could provide sulficient energy for the initiation of an explosion. A collapsed roof also might split open several drums, releasing potentially explosive gases into the air that might then be ignited by a nearby spark or tlame. Again, this scenario should be bounded by the box toppling or MCF evaluations.

8.2.2.3 Localized Hydrogen Accumulation. Flame or spark-initiated scenarios include an explosion caused by a localized accumulation of explosive gases in the RE. Hydrogen gas or other potentially explosive gases might be released from an accidental puncture or rupture of a drum during waste retrieval. Gases released in a drum explosion or from radiolytic decomposition of the waste in breached drums are other possible sources. Lighter-than-air gases such as hydrogen or methane will tend to accumulate along the ceiling, while heaver-than-air gases like propane will build up in depressions on the floor. The flow velocity of the ventilation system and the slow gas generation rates in breached containers preclude such accumulations in any significant amounts.

The isolation unit is being designed to provide localized isolation around breached or contaminated containers. The volume of this unit is significantly smaller than the work area, and the potential may exist for a localized accumulation of hydromen within this unit. This possibility will be evaluated during the design of the unit and results or this evaluation will be documented in the FSAR. 
8.2.2.4 Other Flammable Liquids in the Waste. Extremely small quantities of flammable liquids (e.g., butyl and methyl alcohol) exist in the waste containers (Gratson 1990). Fire and explosion scenarios involving these liquids will be bound by the hydrogen explosion scenario presented in Section 8.4.4.

\subsubsection{Spills}

Two accident scenarios were postulated to evaluate the impacts of waste container handling operations resulting in off-normal events:

- A dropped or punctured and breached waste box inside the RE, (6.0E-03 event/yr)

- A dropped or punctured and breached waste box outside, between facilities (1.2E-02 event/yr).

The dropped waste box outside the RE will bound the release of radiological and hazardous materials offsite. A dropped box between facilities is possible while transporting waste containers between the RE, WSF Type I module, SWEPP, or a WSF Type II module. A punctured waste box could be expected to result in a smaller percentage of waste exposed to the atmosphere and, therefore, have no greater consequences than for a dropped box.

The failed box is assumed to be $100 \%$ filled (i.e., $112 \mathrm{ft}^{3}$ ) with waste having both the average radionuclide and hazardous material inventories. The estimated probability that this container also contains a maximum inventory of radionuclides is $1.0 \mathrm{E}-05$. The probability for this event sequence then becomes $1.2 \mathrm{E}-02 \times 1.0 \mathrm{E}-05=1.2 \mathrm{E}-7 / \mathrm{yr}$, which is below the credibility limit for DOE operations $(<1.0 \mathrm{E}-06$ event/yr). Therefore, the average contents are assumed for the scenario.

It was assumed that $10 \%$ of the material inside the box would be spilled. An estimated release fraction of $1.0 \mathrm{E}-04$ of the spilled radioactive and nonvolatile hazardous materials in the breached waste box was assumed to become airborne when the drop occurred. It is assumed that $100 \%$ of the VOCs will become airborne. The total amount of radioactive material released will be $1.8 \mathrm{E}-04 \mathrm{Ci}$.

$$
1.8 E-04 C i=1 \text { box } \times \frac{112 f^{3}}{b o x} \times \frac{0.16 C i}{f t^{3}} \times 0.1 \times 1.0 E-04
$$

8.2.3.1 Radiological Impact of Dropped Box. The radionuclide releases for the dropped box are presented in Table 15 (DOE 1992a). An instantaneous puff release from a ground-level source was used to determine the radionuclide air concentrations at WMF-613, EBR-I, and the Site boundary for a box dropped between facilities. The time-integr ated expression of the instantaneous puff model was used to determine the time-integrated atmospheric dispersion factor $(\chi / Q)$ from which the time-integrated air concentrations were det-rmined. The following conservative assumptions were used in the analysis: (a) the source was modeled as an instantaneous puff release at ground-level, (b) conservative meteorological conditions were assumed, which consisted of stable atmospheric conditions and a windspeed of $2 \mathrm{~m} / \mathrm{sec}$, and (c) the receptor was present for the entire duration of puff passage (DOE 1992a). 
Table 15. Radionuclide releases for the dropped box accident (DOE 1992a).

\begin{tabular}{lll} 
Radionuclide & IP & $\begin{array}{l}\text { Dropped box } \\
\text { (Ci released) }\end{array}$ \\
\hline Pu-238 & $1.65 \mathrm{E}-01$ & $3.02 \mathrm{E}-05$ \\
Pu-239 & $1.08 \mathrm{E}-01$ & $1.98 \mathrm{E}-05$ \\
Pu-240 & $2.49 \mathrm{E}-02$ & $4.55 \mathrm{E}-06$ \\
Pu-241 & $4.26 \mathrm{E}-01$ & $7.80 \mathrm{E}-05$ \\
Pu-242 & $1.96 \mathrm{E}-06$ & $3.58 \mathrm{E}-10$ \\
Am-241 & $2.55 \mathrm{E}-01$ & $\frac{4.67 \mathrm{E}-05}{1.79 \mathrm{E}-04}$ \\
Total & & \\
\hline
\end{tabular}

CEDE impacts were estimated for the workers and offsite maximally exposed members of the public. DOE dose factors were used to evaluate committed CEDEs. CEDE impacts for the workers and public receptors are given in Table 16 for the accident scenarios (DOE 1992a). These releases were calculated as follows:

release $=I P \times V C \times 0.16 \times .1 \times 1.0 E-04$.

where

$$
\begin{array}{ll}
\mathrm{IP} & =\text { fraction of source term for a particular isotope }=\text { see Table } 15 \\
\mathrm{VC} & =\text { volume per box }-\mathrm{ft}^{3}=112 \\
0.16 & =\text { average source term }=0.16 \mathrm{Ci} / \mathrm{ft}^{3} \\
.1 & =\text { fraction spilled from the box } \\
1.0 \mathrm{E}-04 \quad=\text { resuspension factor (includes respirable fraction) }
\end{array}
$$


Table 16. CEDEs resulting from dropped box accidents (DOE 1992a).

\begin{tabular}{|c|c|c|}
\hline Population group & $\begin{array}{l}\text { Received dose } \\
\text { (rem) }\end{array}$ & $\begin{array}{l}\text { Allowable dose } \\
\quad \text { (rem) }\end{array}$ \\
\hline \multicolumn{3}{|l|}{ Box drop in the RE } \\
\hline Workers in the RE & $4.9 E+00$ & $5.0 \mathrm{E}+00$ \\
\hline \multicolumn{3}{|l|}{ Box drop between facilities } \\
\hline $\begin{array}{l}\text { Workers at WMF- } 613 \text { (137 m from } \\
\text { the accident site) }\end{array}$ & $2.1 \mathrm{E}+00$ & $5.0 \mathrm{E}+00$ \\
\hline Public at EBR-I & $2.2 \mathrm{E}-02$ & $5.0 \mathrm{E}-01$ \\
\hline Public at the Site boundary & $4.5 E-03$ & $5.0 \mathrm{E}-01$ \\
\hline
\end{tabular}

8.2.3.2 Nonradiological Impact of Dropped Box. The hazardous chemicals that were assumed to be available for the accident releases are presented in Tables 17 and 18 (DOE 1992a). To model the maximum RE worker intake of dispersed chemicals in a dropped box accident, a source-compartment kinetic model was used to determine the reduction in air concentration with time. Offsite exposure to hazardous chemicals from the dropped box accident scenarios was modeled using the Gaussian puff model (DOE 1992a). Dispersion of the released material to off-site receptors was modeled using conservative meteorological conditions of Stability Class $\mathrm{F}$ and $2 \mathrm{~m} / \mathrm{sec}$ windspeed.

Table 19 presents the calculated worker and public health risks for exposure to the accident releases of hazardous chemicals. Estimates of worker and public exposure intakes were compared with TWA TLVs, respectively, to obtain HIs. A HI $<1 \mathrm{E}+00$ implies that the exposure to the given chemical is considered acceptable for this conservative scoping analysis.

These results indicate that exposures to hazardous chemicals for the accidents will be below health-based reference levels. The TLV-based acceptable intake is a conservative, upper-bound reference level for an acute accident exposure because it is based on an $8 \mathrm{hr} /$ day intake. A comparison of the receptor intake to other acute reference levels (e.g., immediately dangerous to life and health values) is not necessary if the TLV-based HIs are $<1 \mathrm{E}+00$.

\subsubsection{Criticality}

Criticality analysis for 55- and 83-gal drums are documented in Section 5.3.5 of the RWMC SAR (EG\&G 1986). The results presented indicate criticality involving these drums is an incredible event.

The following sections summarize the results of analysis conducted to justify why potential criticality scenarios associated with firewater actuation and storage of 30 -gal waste drums are below the credibility limit for DOE operations $(<1.0 \mathrm{E}-06$ event/yr). The calculations used the three-dimensional Monte-Carlo code, KENO-V.a, and the one-dimensional $S_{n}$ Discrete-ordinates 
Table 17. Average container headspace concentrations and releases of VOCs (DOE 1992a).

\begin{tabular}{lll} 
Volatile organic compound & $\begin{array}{c}\text { Average } \\
\text { concentration } \\
(\mathrm{g} / \mathrm{L})\end{array}$ & $\begin{array}{l}\text { Airborne } \\
\text { Release }^{\mathrm{b}} \\
(\mathrm{g})\end{array}$ \\
\hline Carbon tetrachloride & $1.9 \mathrm{E}-03$ & $5.70 \mathrm{E}+00$ \\
Methylene chloride & $5.0 \mathrm{E}-04$ & $1.51 \mathrm{E}+00$ \\
$1,1,1$-trichloromethane & $1.3 \mathrm{E}-02$ & $3.93 \mathrm{E}+00$ \\
$1,1,2$-trichloro-1,2,2-trifluoroethane & $1.2 \mathrm{E}-03$ & $3.62 \mathrm{E}+00$ \\
Trichloroethylene & $7.0 \mathrm{E}-04$ & $2.11 \mathrm{E}+00$ \\
& & \\
\hline & & \\
a. Data from Clements and Kudera (1985). & & \\
& & \\
b. Based on 100\% release of VOC gas concentrations within the entire volume of the waste box.
\end{tabular}

Table 18. Average source terms and airborne particulate releases (DOE 1992a).

\begin{tabular}{lll}
\hline & $\begin{array}{c}\text { Source term } \\
(\mathrm{g})\end{array}$ & $\begin{array}{c}\text { Airborne release } \\
(\mathrm{g})\end{array}$ \\
\hline Chemical & $1.82 \mathrm{E}+04$ & $1.82 \mathrm{E}-01$ \\
Lead & $6.62 \mathrm{E}+00$ & $6.62 \mathrm{E}-05$ \\
Beryllium & $4.63 \mathrm{E}+02$ & $4.63 \mathrm{E}-03$ \\
Asbestos & $3.02 \mathrm{E}-02$ \\
& $3.02 \mathrm{E}+0.3$ & \\
& & \\
a. Average mass of chemical constituents in a waste box. & \\
b. Based on $10 \%$ spill and release fraction of 1.0E-04 (DOE 1992a). \\
c. Assumes that $50 \%$ of the waste asbestos is friable (DOE 1992a).
\end{tabular}


Table 19. TLV-based HIs resulting from the dropped box accident scenario (DOE 1992a).

\begin{tabular}{|c|c|c|c|c|}
\hline \multirow[b]{2}{*}{ Chemical } & \multirow{2}{*}{$\frac{\mathrm{RE}}{\text { Worker }}$} & \multicolumn{3}{|c|}{ Between facilities } \\
\hline & & WMF-613 & EBR-I & Site boundary \\
\hline Carbon tetrachloride & $2 \mathrm{E}-03$ & 7E-04 & $7 \mathrm{E}-04$ & $1 \mathrm{E}-04$ \\
\hline Methylene chloride & $6 \mathrm{E}-0.5$ & $3 E-05$ & $3 E-05$ & $6 \mathrm{E}-06$ \\
\hline 1,1,1-trichloroethane & $2 \mathrm{E}-05$ & $7 \mathrm{E}-06$ & $7 \mathrm{E}-06$ & $2 \mathrm{E}-06$ \\
\hline 1,1,2-trichloro- & & & & \\
\hline 1,2,2-trifluoroethane & 4E-06 & $2 \mathrm{E}-06$ & $2 \mathrm{E}-06$ & $3 \mathrm{E}-07$ \\
\hline Trichloroethylene & $6 \mathrm{E}-05$ & $3 E-05$ & $3 E-05$ & $6 \mathrm{E}-06$ \\
\hline Lead & $1 \mathrm{E}-02$ & $4 \mathrm{E}-03$ & 4E-03 & $9 \mathrm{E}-04$ \\
\hline Cadmium & $1 \mathrm{E}-05$ & $5 E-06$ & $5 \mathrm{E}-06$ & $1 \mathrm{E}-06$ \\
\hline Beryllium & $2 \mathrm{E}-02$ & $8 \mathrm{E}-03$ & $8 \mathrm{E}-03$ & $2 \mathrm{E}-03$ \\
\hline Asbestos & $3 E-02$ & $1 \mathrm{E}-02$ & $1 E-03$ & $2 E-04$ \\
\hline
\end{tabular}

transport theory code, SCAMP. KENO-V.a has been validated for proper operation on the INEL Cray and Apollo DN10000 computers.

8.2.4.1 30-Gal Drum Analysis. A criticality analysis was performed on 30-gal drums to determine if the potential existed for a criticality when these size drums are restacked within the RE. Restacking may occur, for example, for transporting containers out of the RE.

The following conservative analysis discusses the criticality potential of arrays of 30 -gal drums containing $200 \mathrm{~g}$ of ${ }^{239} \mathrm{Pu}$ each. For this analysis a semi-infinite array of waste drums is considered. The drums are constructed of 18 gauge carbon steel and have inside dimensions of $28 \mathrm{in}$. high $\times$ $18 \mathrm{in}$. in diameter. The 30-gal drums are stacked on an asphalt or concrete pad in a close-packed configuration, typically with plywood positioned between each level.

The drums were modeled in either a close-packed, triangular-pitch configuration or close-packed, square-pitch configuration. Stacks of drums two, three, four, and five high were evaluated. The fuel loading and configuration was uniform throughout the entire array. This configuration is considered by project personnel to envelope all waste forms that will be stored at the facilities.

The results for the close-packed, triangular-pitch configuration show a maximum stack height of two drums is required to ensure the $k_{\text {eff }}$ of the semi-infinite array of $200 \mathrm{~g}{ }^{239} \mathrm{Pu}$ loaded drums is below 0.95 . The close-packed, square-pitch configuration was found to be less reactive than the triangular-pitch configuration.

An alternative moderator, polyethylene, was also evaluated in the 30-gal drum configurations. The $\mathrm{k}_{\text {eff }}$ for the polyethylene moderated drums is very comparable to the water moderated drums. The results show that a stack height of two drums is required to ensure the $k_{\text {eff }}$ of the semi-infinite array of $200 \mathrm{~g}{ }^{239} \mathrm{Pu}$ loaded drums is below 0.95 . This analysis is currently being upgraded. These results, which are being prepared to Quality Level A requirements and represent current information, will be used for Operational Safety Requirements if restacking of drums within the RE is required. 
Existing drums, which were configured according to procedure, do not present any safety-related problems.

8.2.4.2 Firewater Actuation Analysis. A criticality analysis was completed to determine the firewater collection tanks presented a criticality potential. Details of the analysis are provided in Dafoe (1992). The conclusions of this analysis are that, even under very conservative assumptions, a criticality in the firewater collection tanks is not obtainable.

The analysis reviewed the existing RWMC database for drum content and estimated the $\mathrm{Pu}$ content of each content code. The analysis then assumed that a volume of containers $150 \times 12 \times 16 \mathrm{ft}$ high was exposed. (During operation this is the maximum volume of which containers could be uncovered hecause of physical limitations of retrieval equipment.) It was then assumed that the containers within this volume consisted of the highest Pu content containers. Firewater discharged for 20 minutes over these containers was assumed to be leaching contents from these containers. The firewater collection system within the RE then collected the water, deposited the water, and leached contents into the firewater collection tank. The analysis then assumed that the leached $\mathrm{Pu}$ would settle in the first $10 \%$ of the firewater collection tank even though there are no baffles or other physical barriers to cause this occur. The analysis concludes that under these worst case assumptions $542 \mathrm{~g}$ of Pu could be collected in the firewater collection tank. The analysis then goes on to determine that $1,892.5 \mathrm{~g}$ of $\mathrm{Pu}$ are required in this tank configuration to result in a $\mathrm{K}_{\mathrm{eff}}$ of 0.95 .

\subsubsection{Aircraft Impact}

The base probability of an aircraft impact on the RE is estimated to be 1.07E-08 (Ebasco 1991). This is below the credibility limit for DOE operations ( $<1.0 \mathrm{E}-06$ event/yr). Aircraft impacts on the RE are, therefore, not analyzed further. Refer to Section 5.3.6 of the RWMC SAR (EG\&G 1986) for more information on aircraft impacts. INEL is designated as a national security area which means aircraft cannot thy below $6,0(0) \mathrm{ft}$, and even when lower altitude llights are permitted a $1,00(0) \mathrm{ft}$ standoff distance has been implemented at the RWMC for all aircraft. The helicopter landing pad has been closed for use; should its future use be proposed an Unreviewed Safety Question determination will be made.

\subsubsection{Loss of Power}

Loss of electrical power during operations of the RE will not increase the probability of releases of any radioactive or hazardous materials. Should power be lost to the main distribution panels, the exhaust and supply fans will coast down. Retrieval operations will cease until power is restored. There are no critical loads to the building or any equipment within the RE.

\subsubsection{Industrial Safety}

A review and analysis was performed to support identifying potential industrial safety hazards (Ebasco 1991) at the RE. All hazard outcomes identified which could result in release of radioactive o razardous chemical material will not lead to any accident types or results that are not represented b) e accident analysis presented. 


\subsection{Construction Accidents}

To minimize the risk of lifting building trusses during the construction of the building, several conditions will be placed on the subcontractor. First, the subcontractor will be selected based on experience in erecting buildings of this type. In addition, the lifting of trusses and other associated steel over pads TSA-1, TSA-2, and TSA-R are classified as a high consequence lift in the DOE Hoisting and Rigging Manual. This classification will require verifiable load testing of the cranes. The subcontractor must also show that the crane operator is qualified and provide detailed lifting procedures.

\subsection{Bounding Accident Summary}

Three accident types dominate the accident analysis for the TSA RE: box spill, earthquake/construction, and fire. Preceding section of this chapter have presented the results of detailed studies performed over a two year period to identify, discuss, and evaluate a number of postulated events for each of these accident types. This action provides scoping evaluations which reasonably bound the potential consequences of each accident type. Subsequent evaluations, to be presented in the FSAR, will refine the analyses provided in preceding sections. This section provides assurance that none of the postulated accijents, regardless of probability of occurrence or subsequent refinements, are of such a magnitude as to make the basic RE design approach unaceptable.

The primary mechanism of harming the health of personnel potentially affected by accidents analyzed is through inhalation (or ingestion) of radiological and hazardous chemical materials. Therefore, the primary issue of concern is how much of a given hazardous material does an individual take into their body through inhalation during an accident scenario. For the scoping calculations of this section the following simplified expression is used to make this determination:

release rate $\times \frac{X}{Q} \times$ breathing rate $\times$ time of exposure $=$ inhalationdose

where

$$
\begin{aligned}
& \text { release res:e }=\text { curies or grams per unit of time } \\
& \mathrm{X} / \mathrm{Q}=\text { time per unit of volume } \\
& \text { breathing rate }=\text { volume per unit of time } \\
& \text { time of exposure }=\text { time } \\
& \text { inhalation dose }=\text { curies or grams deposited in an individual's body. }
\end{aligned}
$$

The expression X/Q accounts for the dilution of a release at some specified distance downstream of the release under given meteorological conditions. 
Many determinations or assumptions must be made to evaluate the above expression for a given scenario. Some of the variables that must be determined or assumed are:

- The source term (the numerator of the rclease rate). The source term is the quantity of each hazardous material potentially released because of the accident. The release fraction of each hazardous material must also be determined or assumed. The release fraction is a function of numerous variables (e.g., temperature, time at temperature, physical and chemical characteristics of a hazardous material, barriers to release, etc.). Only a portion of the release fraction is respirable. This "respirable fraction" must also be determined or assumed.

- Duration of the release (the denominator of the release rate). In evaluating hypothetical accident scenarios, an assumption must be made about the time frame over which the release occurs. This is an important assumption because increasing the duration of the release of a fixed quantity of material will decrease the internally-received dose of a receptor per unit of time; conversely, decreasing the duration will give the receptor a larger internal dose per unit of time.

- $\mathrm{X} / \mathrm{Q}$ is evaluated using a specified distance from the origin of the release. Therefore, distances of particular importance in the analysis must be determined or assumed. Rigorously derived expressions for evaluating $X / Q$ are not accurate for areas in close proximity to the origin of the release; therefore, an alternate method for determining a $\mathrm{X} / \mathrm{Q}$ value must be used. Other key parameters used to assess $\mathrm{X} / \mathrm{Q}$ are the windspeed and the stability of the meteorological conditions (i.e., Pasquill Class A through $F$ meteorological stability conditions).

- A breathing rate of $3.5 \mathrm{E}-04 \mathrm{~m}^{3} / \mathrm{sec}$ is used based on DOE-STD-1027-92 (DOE 1992c).

- It can be difficult to achieve a realistic determination or assumption of the receptor's time of exposure when evaluating hypothetical accident scenarios. Even when the release occurs over a relatively short time frame (e.g., a dropped box), it is a poor assumption that a trained radiological worker would stand anywhere near the plume or the downwind side of a known release for an extended period. In fact, radiological workers are trained to immediately evacuate any area that is suspected of containing airborne contamination and RE procedures will explicitly require such actions.

Plywood boxes are used in these bounding calculations because they are most easily ignited and breached. There are 897 plywood boxes (all on pad TSA-1), 7,231 FRP boxes in the TSA-RE inventory, and 258 odd sized boxes to be recovered in the RE. At any one time a maximum of 72 boxes could be exposed on the stack face. The Hot Area could contain 1 to 5 containers, the Cold Area could contain 1 to 10 containers, and the loaded truck could contain a maximum of 40 containers. Once the MCF scenario is restudied for the FSAR, it is possible that some of these limits will be redefined in order to limit possible fire consequences. 


\subsubsection{Spilled Box Radiological}

A bounding spilled box accident radiological dose calculation can be a simplified and summarized as follows:

$c=r \times \frac{X}{Q} \times b \times e$

where

c $\quad=$ curies inhaled

$r=$ release rate for puff release $(\mathrm{Ci} / 60 \mathrm{sec})$

$X / Q=60 \mathrm{sec} / 5,000 \mathrm{~m}^{3}$

$r \times X / Q$ represents the "cloud" of respirable material within the TSA-RE; no credit is taken for ventilation. This approach was taken because of the close proximity to the origin of release. A cloud volume of $5,000 \mathrm{~m}^{3}$ is conservatively used (the difference between the shroud to shroud volume and the stack volume is approximately $16,000 \mathrm{~m}^{3}$ ).

b = breathing tate $\left(3.5 \mathrm{E}-04 \mathrm{~m}^{3} / \mathrm{sec}\right)$

e $\quad=$ exposure time (sec).

Table 20 was developed from the source term information presented in Table 4 to investigate the consequences of this event. Therefore, there are $0.55 \mathrm{Ci} / \mathrm{g}$ of a composite of TRU isotopes at TSA-RE. Based on the data sheets available, the average plywood box contains some 766/522 a $1.5 \mathrm{gms}$ of TRU/box (plywood boxes are most likely to breach). For conservatism, assume that the dropped box contains $15 \mathrm{gms}$, an order of magnitude greater inventory. The activity for the maximum loaded box is then estimated to be $15 \mathrm{~g} \times .55=8.25 \mathrm{Ci}$. The total amount of radioactive material released will be $8.25 \mathrm{E}-05 \mathrm{Ci}$. The release fraction is the same as used in Section 8.2.3.

Based on the assumption, if $r=8.25 \mathrm{E}-05 \mathrm{Ci} / 60 \mathrm{sec}$

and $\mathrm{e}=300 \mathrm{sec}$, then

$c=8.25 \mathrm{E}-05 \mathrm{Ci} / 5,000 \mathrm{~m}^{3} \times 3.5 \mathrm{E}-04 \mathrm{~m}^{3} / \mathrm{sec} \times 300 \mathrm{sec}=1.7 \mathrm{E}-09 \mathrm{Ci}$.

Using a dose conversion factor equal to $2.0 \mathrm{E}+08 \mathrm{rem} / \mathrm{Ci}$, which is calculated as follows: 


\begin{tabular}{cccc}
\hline Isotope & $\begin{array}{c}\text { CEDE } \\
(\mathrm{rem} / \mathrm{Ci})\end{array}$ & $\begin{array}{c}\text { Weighted factor from } \\
\text { Table 20 }\end{array}$ & $\begin{array}{c}\text { Dose conversion } \\
\text { factor } \\
(\mathrm{rem} / \mathrm{Ci})\end{array}$ \\
\hline Am-241 & $5.2 \mathrm{E}+08$ & $\times .12 / .55$ & $=1.13 \mathrm{E}+08$ \\
Pu-238 & $3.0 \mathrm{E}+08$ & $\times .09 / .55$ & $=0.49 \mathrm{E}+08$ \\
Pu-239 & $3.3 \mathrm{E}+08$ & $\times .05 / .55$ & $=0.30 \mathrm{E}+08$ \\
Pu-240 & $3.3 \mathrm{E}+08$ & $\times .01 / .55$ & $=0.06 \mathrm{E}+08$ \\
Pu-241 & $5.7 \mathrm{E}+07$ & $\times .28 / .55$ & $=0.03 \mathrm{E}+08$ \\
\hline & & & $2.00 \mathrm{E}+08$
\end{tabular}

a. Dose conversion factors from Internal Dose Conversion Factors for Calculation of Dose to the Public, DOE/EH-0071, July 1988, are used to calculate the dose conversion factor.

results in

dose $=\mathrm{d} \times \mathrm{c}=1.7 \mathrm{E}-09 \mathrm{Ci} \times 2.0 \mathrm{E}+08 \mathrm{rcm} / \mathrm{Ci}=0.4 \mathrm{rem}$.

The same calculation for FRP boxes will increase the curies released by a factor of 2 for a release of 1.8E-04 (see equation 7). Which results in,

$c=1.8 \mathrm{E}-04 \mathrm{Ci} / 5,000 \mathrm{~m}^{3} \times 3.5 \mathrm{E}-04 \mathrm{~m}^{3} / \mathrm{sec} \times 300 \mathrm{sec}=0.37 \mathrm{E}-08 \mathrm{Ci}$.

dose $=\mathrm{d} \times \mathrm{c}=0.37 \mathrm{E}-08 \mathrm{Ci} \times 2.0 \mathrm{E}+08 \mathrm{rem} / \mathrm{Ci}=0.8 \mathrm{rem}$.

A conservative factor of 10 increase in inventory will increase the dose to $8 \mathrm{rem}$.

Table 20. Specific activity.

\begin{tabular}{|c|c|c|c|c|c|}
\hline Isotope & $\begin{array}{l}(\mathrm{A}) \\
\text { Decayed } \\
\text { activity } \\
(\mathrm{Ci})^{\mathrm{a}}\end{array}$ & $\begin{array}{c}\text { (B) } \\
\text { Specific activity } \\
(\mathrm{Ci} / \mathrm{g})\end{array}$ & $\begin{array}{l}(A+B) \\
\text { Mass } \\
(g)\end{array}$ & $\begin{array}{c}\text { (C) } \\
\text { Mass as a \% } \\
\text { of total mass }\end{array}$ & $\begin{array}{c}(B \times C) \\
\text { Weighted specific activity } \\
(\mathrm{Ci} / \mathrm{g})\end{array}$ \\
\hline Am-241 & $8.77 E+04$ & 3.24 & $27,067.9$ & 3.75 & 0.12 \\
\hline Pu-238 & $6.30 E+04$ & 17.49 & 3,602 & 0.5 & 0.09 \\
\hline $\mathrm{Pu}-239$ & $4.01 E+04$ & 0.0614 & $653,094.5$ & 90.2 & 0.05 \\
\hline Pu-240 & $8.91 E+03$ & 0.23 & $38,739.1$ & 5.3 & 0.01 \\
\hline Pu-241 & $2.05 E+05$ & 112.52 & $1,821.9$ & 0.25 & 0.28 \\
\hline Total & & & $724,325.4$ & & 0.55 \\
\hline
\end{tabular}

a. Sec Table 4. 
Proper filter system operations, or in its absence building holdup and plateout makes offsite and co-located worker doses sufficiently small that they are not of practical importance.

8.4.1.1 Spilled Box Chemical. The chemical release calculation can be simplified as follows:

$$
\begin{aligned}
& C=r \times \frac{X}{Q} \\
& C \quad=\text { concentration }(g / \text { volume }) \\
& r \quad=\text { release rate for puff release }(\mathrm{g} / 60 \mathrm{sec}) \\
& \mathrm{X} / \mathrm{Q}=60 \mathrm{sec} / 5,000 \mathrm{~m}^{3}
\end{aligned}
$$

The hazardous material source term used (Gratson 1990) is based on conservative values, and $100 \%$ of the VOC gas is assumed released. Therefore, the chemical relcase is bounding as presented. Table 19 also shows that a several order of magnitude increase in chemical weight would be required to reach the threshold for each chemical. The total $\mathrm{HI}$ is based on a sum of conservative values and, therefore, would be even more bounding.

\subsubsection{Earthquake/Construction Radiological}

The bounding construction accidents would be dropping a truss on the (buried) stack or puncturing of (buried) boxes with construction equipment. Dropping a truss would be bounded by the earthquake with structural damage accident, considering that the dirt cover should provide some protection and filtering. This accident was calculated to result in 3.9E-03 $\mathrm{Ci}$ of release. Twenty-two FRP boxes were involved. Because there is not a facility structure, a X/Q value of $1.0 \mathrm{E}-04 \mathrm{sec} / \mathrm{m}^{3}$ is used (as recommended by DOE-STD-1027-92 for onsite calculations). Five minutes is assumed for release and an exposure time is $\mathbf{3 0}$ minutes. The more coriservative $\mathbf{3 0}$ minute exposure is assumed because either a construction accident or an earthquake could result in sufficient confusion to permit workers to forget or forego their normal training.

$c=3.9 \mathrm{E}-03 \mathrm{Ci} / 300 \mathrm{sec} \times 1.0 \mathrm{E}-04 \mathrm{sec} / \mathrm{m}^{3} \times 3.5 \mathrm{E}-04 \mathrm{~m}^{3} / \mathrm{sec} \times 1,800 \mathrm{sec}=8.2 \mathrm{E}-10 \mathrm{Ci}$

dose $=8.2 \mathrm{E}-10 \mathrm{Ci} \times 2.0 \mathrm{E}+08 \mathrm{rcm} / \mathrm{Ci}=0.16 \mathrm{rcm}$.

Even assuming that an entire exposed stack face was breached by this accident, the calculated dose would increase by a factor of $80 / 22$ or 3.6 . While highly unlikely, this value represents a very conservative bounding limit.

Public exposure at $6 \mathrm{~km}$ calculates to be approximately $1.0 \mathrm{E}-02$ less with no allowance for deposition, and it is not significant when compared to the 0.5 rem criterion. 
8.4.2.1 Earthquake/Construction Chemical. The assumed 22 box breach would increase the chemical concentrations of the outside dropped box by a factor of 22 . However, this would not increase the hazard indices presented in Table 19 enough to allow them to exceed the threshold.

\subsubsection{Maximum Credible Fire}

The MCF is the bounding accident for the TSA-RE. For the calculations provided in Section 8.2.1.1.1 a total of $.34 \mathrm{Ci}$ are released. It is assumed 19 boxes and 72 drums are involved. This inventory is based on a scenario and inventory believed to realistically bound postulated events. It is, however, possible that other scenarios could be postulated which would result in slightly different conclusions. It is EG\&G Idaho's intention to more carefully study possible fire initiating scenarios and to reassess mitigating action or equipment. For this reason, a bounding fire scenario is presented to assure that all potential conclusions and/or mitigation are covered. This scenario is based on a maximum inventory of 20 plywood boxes, a limit which will be firmly assured in the FSAR. (A number of practical ways such as full time fire watches, not uncovering more than 20 plywood boxes at a time, safety grade fire detection and mitigation or possibly others are available to assure that this 20 box limit is achieved.) The fire is assumed to burn for a two hour period during which time all radiological and hazardous material is released. Release is at ground level and conservative dispersion factors are used throughout. The dispersion factors were calculated using RSAC (Wenzel 1990). Receptors both on and off-site are assumed to remain in the release cloud for the entire accident duration. TRU inventory of the 20 boxes is assumed to be an order of magnitude above average, i.e., $15 \mathrm{gm}$ TRU/box. The 72 drums also assumed to be involved contain average anticipated inventories of both TRU and hazardous chemicals. It is believed that this combination of assumptions represents a conservative upper bound for identifying the consequences of any possible fire at the RE.

\section{Source term}

Curies per plywood box $=15 \mathrm{gm} \times 0.55 \mathrm{Ci} / \mathrm{gm}=8.25 \mathrm{Ci}$

Curies per drum $=0.16 \mathrm{Ci} / \mathrm{ft}^{3} \times 7.3 \mathrm{ft}^{3}=1.17 \mathrm{Ci}$

Total curies in fire $=8.25 \mathrm{Ci} \times 20$ boxes $+1.17 \mathrm{Ci} \times 72$ drums $=249 \mathrm{Ci}$

Dose to co-located worker at $100 \mathrm{~m}$

Using a 1.0E-03 release fraction as recommended by DOE-STD-1027-92 (DOE 1992c), and a conservative $\mathrm{X} / \mathrm{Q}$ of $8.5 \mathrm{E}-0.3 \mathrm{sec} / \mathrm{m}^{3}$ (Class $\mathrm{F}$ stability with wind speed equal to $0.5 \mathrm{~m} / \mathrm{sec}$ meteorology)

$\mathrm{c}=249 \times 1.0 \mathrm{E}-03 / 7200 \mathrm{Ci} / \mathrm{sec} \times 8.5 \mathrm{E}-03 \mathrm{sec} / \mathrm{m}^{3} \times 3.5 \mathrm{E}-04 \mathrm{~m}^{3} / \mathrm{sec} \times 7200 \mathrm{sec}$

$=7.4 \mathrm{E}-07 \mathrm{Ci}$

dose $=7.4 \mathrm{E}-07 \mathrm{Ci} \times 2.0 \mathrm{E}+08 \mathrm{rem} / \mathrm{Ci}=148 \mathrm{rem}$ 


\section{Dose to public at $6 \mathrm{~km}$}

Same equation as above except for a X/Q of $3.1 \mathrm{E}-06 \mathrm{sec} / \mathrm{m}^{3}$ which is based on Class D stability with wind speed equal to $2.0 \mathrm{~m} / \mathrm{sec}$ meteorology.

dose $=3.1 \mathrm{E}-06 / 8.5 \mathrm{E}-03 \times 148 \mathrm{rem}=5.4 \mathrm{E}-02 \mathrm{rem}$

8.4.3.1 Maximum Credible Fire Chemical. The total hazard index of 4.1 would be reduced to 0.06 if the DOE-STD-1027-92 recommended meteorology is used. This hazard index presented in Section 8.2.1.1.2 for this accident is bounding as it is based on the sum of conservative values based on Gratson (1990).

\subsubsection{Drum Explosion and Fire}

The drum explosion and fire accident involves a handling accident resulting in the explosion and subsequent burning of a single drum containing combustible radiological and hazardous wastes. The drum is punctured or dropped, accompanied by a spark that ignites hydrogen or volatiles in the drum, resulting in an explosion. Subsequently, the combustibles in the drum burn completely before the fire can be extinguished. See Section 8.2.2.1 for the drum explosion accident description.

The following calculation estimates the worker dose for this accident. As in the case of the more likely dropped box accident proper filter system operations, or in its absence building holdup and plateout makes offsite and co-located worker doses sufficiently small that they are not of practical importance.

Assuming the entire contents burns, $1.17 \mathrm{Ci}$ are released. A release fraction of $1.0 \mathrm{E}-03$ based on DOE-STD-1027-92 (DOE 1992c) is used.

$$
\begin{aligned}
& c=1.17 \times 1.0 \mathrm{E}-03 \mathrm{Ci} / 5000 \mathrm{~m}^{3} \times 3.5 \mathrm{E}-04 \mathrm{~m}^{3} / \mathrm{sec} \times 300 \mathrm{sec}=2.5 \mathrm{E}-08 \mathrm{Ci} \\
& \text { dose }=2.5 \mathrm{E}-08 \mathrm{Ci} \times 2.0 \mathrm{E}+08 \mathrm{rem} / \mathrm{Ci}=5.0 \mathrm{rem}
\end{aligned}
$$

The hazardous chemical release will be bounded by the maximunı credible fire because more inventory of the same material is involved. 


\section{CONDUCT OF OPERATIONS}

The conduct of operations presented in this PSAR discuss the construction and preoperational testing. Prior to operation the FSAR for this facility will provide a discussion on the conduct of retrieval operations. This discussion will be in accordance with the requirements of DOE 5480.23 and 5480.19

\subsection{Construction Organization}

During the construction of the TSA RE, management of the project will be divided into three areas of responsibility. Figure 4 provides a simplified construction organization chart.

The MK-FIC Project Manager is responsible for the review and approval of all documents pertaining to the TSA RE project including the Site Healih and Safety Plan. The Project Manager will interface with the RWMC Facility Manager to resolve environmental, safety and health issues.

The Operating Contractor (OC) Project Manager is assigned oversight responsibilities for construction activities and will coordinate these activities with the RWMC Facility Manager.

The RWMC Program Manager is responsible to oversee and coordinate: Site Specific training for all personnel working at the RWMC; emergency response; disposal of waste; and the industrial and radiological hygiene of the construction activities.

The OC Radiological Control Technician (RCT) and staff are responsible for implementing the radiological control requirements of DOE 5480.11 and DOE 5400.5. These duties include survey of construction site for radiological hazards, monitoring of personnel exposure, determination of Personnel Proteciive Equipment (PPE) (respirators, clothing, booties, etc.), survey of personnel and equipment for contamination, and survey of soil to be excavated and determining the soils proper storage, use or disposal.

The OC Industrial Hygienist (IH) and staff provide Industrial Hygiene support for all construction activity including monitoring of all earthwork activities in accordance with DOE 5480.10. The OC IH will provide PPE requirements for chemical hazards associated with this construction project.

The Site Health and Safety Officer (SHSO) is the primary on-site contact for salety and health and ensures the requirements of DOE 5483.1A are implemented during construction activities. Specific responsibilities include:

Provide oversight to verify required level of training of personnel is performed including OSHA 29 CFR 1910.120 training, respirator training, radiation worker training, and emergency response training.

Coordinate the correct field execution of the Site Health and Safety Plan including workplace and personnel monitoring. 


\section{TSA-RE CONSTRUCTION ORGANIZATIONAL CHART}

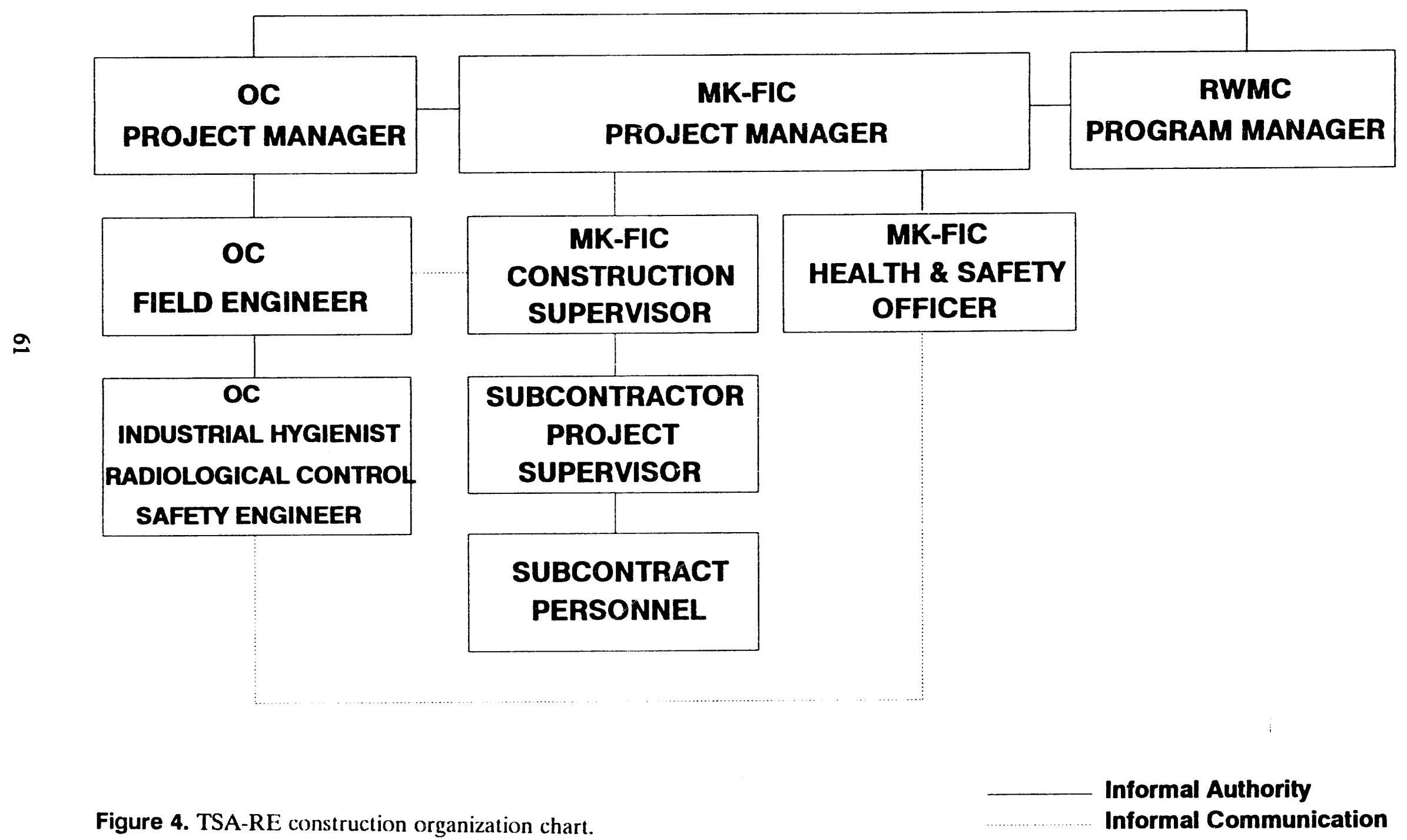


Oversee monitoring/sampling of site hazards for exposure and hazards evaluation.

Coordinate construction site work zones and levels of personnel protection in conjunction with the OC RCT and OC IH.

Coordinate accident prevention through oversite of construction activities and awareness of site operations.

Review and approve Subcontractor Safety Analysis Plans

Provide monthly reports to the Project Manager summarizing inspections, findings, and Corrective Actions.

\subsection{Construction Administrative Controls}

The Site Health and Safety Plan incorporates methods to reduce the probability and consequences of construction accidents and the Project Management Plan implements a Quality Program Plan meeting the requirements of DOE 5700.6C. DOE 5480.5, "Safety of Nuclear Facilities," and DOE 5480.21, "Unreviewed Safety Questions," will also be implemented.

\subsubsection{Training}

All personnel involved in the construction of the TSA RE will receive training applicable to the job function in addition to site access training requirements. All site workers requiring entry to the construction area will have been trained to OSHA 29 CFR 1910.120(e), Hazardous Waste Operations Training as well as Radiological Worker Training. Those workers involved in activities requiring entry into known or suspected contaminated areas will have completed Respirator Training and Fit Test.

\subsubsection{Monitoring}

To ensure that construction activities are conducted in a manner to prevent the spread of hazardous materials or contamination a monitoring program has been implement in the Site Health and Safety Program. Work involving potential exposure to hazardous materials will not be performed unless calibrated and maintained monitoring instruments are available for use and qualified monitoring personnel are available.

Air Monitoring will be conducted to evaluate personal exposure. Sampling data will be used to assess exposure potential. Full time industrial hygiene support (monitoring) will be provided.

Radiation Monitoring will be performed to document exposures and identify radiation work zones. Direct exposure to personnel will be tracked by issuance of individual thermoluminscent dosimeters (TLDs) and supplemental dosimetry as required. 
Soil Monitoring consisting of organic surveys of the soil will be conducted (within one inch of the soil) to determine lower explosive limit (LEL) levels.

All personnel, equipment, and samples leaving the construction site shall be surveyed for radiological contamination. Although contamination is not expected at the construction site, decontamination will be performed as required.

\subsubsection{Hazards and Controls}

Construction activities will be monitored by Safety, Industrial Hygiene and Radiation Control personnel. Hazards identified will be evaluated and necessary controls established. Potential Hazards already identified include: chemical exposures, radiation, excavation, heavy equipment operation, and flammable materials.

Chemical exposure protection will incorporate engineering, administrative and personal protective controls. Prior to sidchurden/overburden removal an exclusion zone will be established. Workers in the exclusion zone will be required to wear respiratory protection. Based on monitoring results of work area, Personal Protection Equipment (PPE) may be made mandatory by the appropriate construction management personnel. No chemical contamination of the sideburden/ overburden soil is expected.

Radiation protection will be provided by monitoring and personnel training. Radiological contamination is not expected during construction activitics. Radiological contamination detected will result in work stoppage until appropriate action is determined. Radiation protection will be in accordance with the requirements of DOE 5480.11.

Fire prevention is provided by engineering and administrative controls. Flammable liquids will be stored in Underwriter Laboratory (UL) approved safety containers designed and labeled for that purpose. Flammable materials will be stored in locations determined by the Site Health and Safety Officer and RWMC Fire Protection Engineer. All hot work (e.g., welding, burning) will require a dedicated fire watch. In the event of a fire, emergency fire brigade personnel are trained in methods/precautions used to combat fires involving hazardous and radioactive material.

Excavations shall be designed in accordance with 29 CFR 1926.650-652 Subpart P. Prior to beginning excavation activities an Excavation/CSWP Permit will be posted at the job site. Prior to beginning excavation activities, a meeting will be held to review the Excavation/CWSP Permit, subcontract drawings and the OC Underground Survey Report to identify all underground installations in the areas to be excavated. Radiation and Industrial Hygiene surveys will be performed during excavation work. Considerations shall be made to prevent possible soil contamination spread. These considerations are, excavation will not he performed in the rain, surface water will be prevented from reaching the excavated area, silt and sediment transfer from the excavated area will be prevented, and prior to pumping water from an excavation the proper disposal method and pumping method will be determined. 


\subsection{Emergency Preparedness}

An Emergency Plan for the RWMC has been prepared for the RWMC site. This plan provides provisions for radiological, hazardous material, industrial, medical, as well natural phenomena accidents/events. This Emergency Plan for the RWMC of which the TSA RE is a part has been implemented in accordance with 40 CFR 265 Subpart D, the DOE 5500 series Orders, and DOE 5000.3A, "Occurrence Reporting."

The RWMC Program Manager or his designated alternate in his absence will be the Emergency Action Director (EAD) responsible for coordinating all emergency actions taken within the facility. The $\mathrm{EAD}$ is responsible for declaring the emergency, determining appropriate actions, and notification of appropriate authorities.

The succession of authority for the RWMC EAD is as follows:

- RWMC Program Manager

- RWMC Operations Manager

- RWMC Shift Manager.

All personnel authorized unescorted access to the site receive training on their responsibilities in the event of an emergency. In the event of an emergency assembly areas are designated for site personnel to allow for accountability. Should site evacuation be required the normal route would be through the Gate House. Alternate routes are available if $t$ yuired due to the nature of the accident or other conditions (e.g., wind direction, contamination of gate house). Personnel are notified of requirement to evacuate by Site Alarm System and a Public Address System. Personnel evacuation from the site area is accomplished by buses.

\subsection{Pre-operational Testing}

Testing and startup of the TSA-RE facility is a joint effort of EG\&G Idaho's Engineering and Construction (E\&CM) Group and Waste Management (WM) Programs. E\&CM is responsible for component testing and acceptance, while WM Programs is responsible for System Operations testing. Both types of testing requircd development of RWMC and DOE-ID approved test plans, procedures and acceptance criteria. Qualified INEL technicians and/or outside vendor personnel will perform the component acceptance test. WM Programs will use qualified EG\&G Idaho personnel to oversee the component testing program and write and perform the system test procedures. WM programs and RWMC management approves and aceepts the facility as operational with final permission to begin operations received from DOE-ID and DOE-Headquarters following a successful Operational Readiness Review. Administrative procedures to control the conduct, acceptance/approval of test results will be in accordance with DOE 5480.19. 


\section{OPERATIONAL SAFETY REQUIREMENTS}

Technical Safety Requirements (TSR) define the operating limits that will ensure the assumptions used in the FSAR accident analysis are maintained. The TSRs for the TSA RE will be developed in accordance with the requirements of DOE 5480.22, "Technical Safety Requirements."

A preliminary development of the bases to be used in the development of the TSR is provided in the remaining sections of this chapter. A more thorough development of these bases will be provided in the FSAR as required by DOE 5480.23.

\subsection{Limiting Conditions of Operations}

\subsubsection{Definition}

Limiting Conditions of Operations (LCO) are defined as the lowest functional capability or performance level of structures, systems, component and their support systems required for normal safe operation of the facility.

\subsubsection{Selection Criteria}

LCOs will be derived based upon the following considerations:

- Instrumentation that is used to detect and indicate a significant degradation of a physical barrier or system that prevents the uncontrolled release of radioactive or hazardous materials

- A structure, system, or eomponent that lunctions or actuates to mitigate accidents or transients that either assume the failure of, or presents a challenge to, a physical barrier or system that prevents the uncontrolled release of radioactive or hazardous materials

- A process variable that is an initial condition for a DBA analysis that assumes the failure of, or presents a challenge to, a radioactive or hazardous material barrier

- A structure, system, or component that operating experience or risk assessment has shown to be a significant contributor to the risk of uncontrolled release of radioactive or hazardous materials.

\subsubsection{Preliminary LCO List}

Based on the above considerations, the following systems have been preliminary identified to require LCOs.

- Fire Detection System

- Fire Suppression System 
- Ventilation System

- $\quad$ Stack Monitoring (radionuclide monitoring)

- Criticality Configuration.

\subsection{Administrative Controls}

\subsubsection{Definition}

Administrative Controls are the provisions relating to organization and management, procedures, recordkeeping, reviews and audits necessary to ensure safe operation of the facility. Items to be included in the Administrative Controls are; reporting requirements for deviations from Technical Safety Requirements, staffing requirements of the facility, and criticality safety program (physical and administrative).

\subsubsection{Preliminary Administrative Control List}

The preliminary list of administrative controls will include:

- Management and Staffing requirements wili be developed in accordance with the requirements of DOE 5480.20

- Incident Reporting Program will be developed in accordance with the requirements of DOE 5000.3A, 5500.2B, and 5480.21

- Procedures Program will meet the requirements of DOE 5480.19 and 5480.22

- Records Retention Program will meet the requirements of DOE 5700.6C

- Configuration Control Program for oversight of hardware and documentation affecting the safety envelope will be developed in accordance with DOE 4330.4A, DOE 5700.6C and DOE 5480.21

- Training Program for Safety-related activities will be developed in accordance with DOE 5480.20

- QA program will meet the requirements of DOE 5700.6C

- Emergency Plan will be developed in accordance with DOE 5500 series. 


\section{REFERENCES}

Abbott, M. L., 1990, Results of CAP-88 Calculations for the Stored Waste Retrieval Environmental Assessment, Engineering Design File, RE-082/RW-018, December 17.

Anderson, S. R. and B. D. Lewis, 1989, Stratigraphy of the Unsaturated Zone at the RWMC, Idaho National Engineering Laboratory, Idaho, Preliminary Draft, U.S. Geological Survey, Idaho Falls, Idaho.

BEIR IV (Committec on Biological Effects of Ionizing Radiation), 1980, The Effects on Populations of Exposures to Low Levels of Ionizing Radiation.

Berry, W. J. and J. L. Petty, 1990, Summary of Available Baseline Environmental Information for the RWMC at the Idaho National Engineering Laboratory, EGG-WM-9063.

Brown, R. M., 1979, INEL Plywood Box Fire Test, EG\&G Idaho, Inc., PR-W-79-028, September.

Butler, R., 1991, Drum stock Stability Evaluation, EG\&G Idaho, Engineering Design File, RWMC405, Rev. 1, June.

Clements, T. L., Jr., 1982, Content Code Assessments for INEL Contact-handled Stored Transuranic Wastes, WM-F1-82-(021.

Clements, T. L., Jr. and D. E. Kudera, 1985, TRU-waste Sampling Program: Volume I: Waste Characterization; Volume II: Gas Generation Studies, EGG-WM-6503.

Dafoe, R. E., 1992, Firewater Drain Tank Criticality, EG\&G Idaho, Engineering Design File, RE-194, August.

Davis, J. N., 1989, letter to B. J. Mikkola, 1989 Integrated Data Base Submittal, JND-129-89, May 15.

Davis, M. L. and D. G. Satterwhite, 1989, Fire Hazards Analysis of the RWMC Air Support Buildings, EGG-WM-8703, September.

DOE (U.S. Department of Energy), 1987, DOE Evaluation Document for DOT 7A Type A Packaging, MLM-3245, EG\&G Mound, March.

DOE, 1988, Final Environmental Impact Statement - Special Isotope Separation Project, DOE-EIS-0136. 
DOE, 1989a, The Idaho National Engineering Laboratory Site Environmental Report for Calendar Year 1988, DOE/ID-12082 (88).

DOE, 1989b, General Design Criteria, DOE Order 6430.1A, April 6.

DOE, 1990, Final Environmental Impact Statement Waste Isolation Pilot Plant, DOE-EIS-0026.

DOE, 1991, "Safety Analysis and Review System," DOE-ID Order 5481.1B.

DOE, 1992a, Environmental Assessment for Transuranic Storage Area Retrieval Enclosure and Waste Storage Facility at the Idaho National Engineering Laboratory, DOE/EA-0499, May.

DOE, 1992b, DOE-ID Architectural Engineering Standards, Rev. 13, September 21.

DOE, 1992c, Hazard Categorization and Accident Analysis Techniques for Compliance with DOE Order 5480.23, Nuclear Safety Analysis Reports, DOE-STD-1027-92, December.

Ebasco (Ebasco Services Incorporated), 1990, Maximum Credible Fire Scenario at the TSA Retrieval Enclosure and TRU Waste Storage Facility, Engineering Design File, December.

Ebasco, 1991, Event Tree Analysis of Potential Accidents at the INEL Radioactive Waste Management Complex TSA Retrieval Enclosure and TRU Waste Storage Facility, January.

EG\&G (EG\&G Idaho, Inc.), 1986, Safety Analysis for the Radioactive Waste Management Complex at the Idaho National Engineering Laboratory, WM-PD-86-011.

EG\&G, 1988, Safety Manual, Supplement 2.3, EG\&G Idaho, Inc., October 1.

EG\&G, 1991, Safety Analysis for the Stored Waste Examination Pilot Plant (SWEPP) at the INEL, WM-PD-87-023, Rev. 2, February.

EG\&G, 1992, Conduct of Operations Manual, current issue.

EPA (U.S. Environmental Protection Agency), 1989, National Emission Standards for Hazardous Air Pollutants; Radionuclides, 54, FR 240, 51654, December 15.

Gratson, M. W., 1990, Hazardous Stored TRU Waste Source Term for the RWMC's TSA, EDF RE-021/RW-008, February.

Lindsay, J. W. and W. E. Downing, 1972, Improvements to a Plywood Container Used for Shipping Alpha Emitting Transuranic Waste, Dow Chemical Company, CRDL 950612-011.

Litteer, D. L., 1989, letter to J. J. Riedesel, Request for RWMIS Data Information ,TSA Waste Data Plus ORIGEN2 Decay and Ingrowth) and ASCII PC-Disk Files, DLL-41-89, August 15. 
McCormack, D., 1992, letter to H. L. Johnson, TSA Retrieval Enclosure and Waste Storage Facility, Supplemental Analyses, Subcontract C90-132744, Task Order 31, EBEL-EGGI/31-L-92-023, December 23.

Mishima, J. and L. C. Schwendiman, 1972, Airborne Release of Plutonium and Its Compound During Overheating Incidents, BNWL-1652, Part 1, Battelle Pacific Northwest Laboratories.

Riedesel, J. J., 1991a, Decay D. Litteer RWMIS 1971 data to 1991, EG\&G Idaho Inc., Engineering Design File, RE-106/RW-018, January.

Riedesel, J. J., 1991b, Weapons Grade Plutonium Decay Using ORIGEN2, EG\&G Idaho, Inc., Engineering Design File, RE-107/RW-019, January.

Rohrig, N. D., 1990, Stack Monitoring Requirements for TSA-Retrieval Enclosure, Engineering Design File, RE-0029, December 4.

RSIC (Radiation Shielding Information Center), 1985, ORIGEN2 Isotope Generation and Depletion Code Matrix Exponential Method, CCC-371, December.

Wenzel, D. R., 1990, Radiological Safety Analysis Computer Program, RSAC-4 Version 4.03, April. 


\section{Appendix A \\ Tentative Hazard Classification}




\section{Tentative Hazard Classification}

DOE Order 5480.23 requires a Tentative Hazard Classification be determined for this activity. The following three DOE Order 5480.23 hazard classes were considered:

1. Category 3 - The hazard analysis shows the potential for only significant localized consequences.

2. Category 2 - The hazard analysis shows the potential for significant onsite consequences.

3. Category 1 - The hazard analysis shows the potential for significant offsite consequences.

A classification of "Category $2^{*}$ was assigned based on the following information.

The maximum credible fire accident presented in Section 8.2.1.1 is the credible accident ihat has the worst consequences (no mitigation of relcase is assumed). Table A-1 shows the received dose and the allowable dose. It shows that the accident results in dose to the worker at $100 \mathrm{~m}$ exceeds the allowable dose. However, the offsite dose is within the allowable dose.

Table A-1. Effective dose equivalent from the Retrieval Enclosure maximum credible fire.

\begin{tabular}{lcccc}
\hline \multicolumn{1}{c}{ Pathway } & $\begin{array}{c}\text { Public dose } \\
6,000 \mathrm{~m} \\
(\mathrm{rem})\end{array}$ & $\begin{array}{c}\text { Allowable } \\
\text { public dose } \\
(\mathrm{rem})\end{array}$ & $\begin{array}{c}\text { Worker dose } \\
100 \mathrm{~m} \\
(\mathrm{rem})\end{array}$ & $\begin{array}{c}\text { Allowable } \\
\text { worker dose } \\
(\mathrm{rem})\end{array}$ \\
\hline Inhalation & $5.1 \mathrm{E}-02$ & - & $2.8 \mathrm{E}+01$ & - \\
Ingestion & $3.4 \mathrm{E}-01$ & - & $\mathrm{NA}$ & - \\
Ground surface & $1.7 \mathrm{E}-06$ & - & $9.2 \mathrm{E}-04$ & - \\
Air immersion & $2.4 \mathrm{E}-09$ & - & $1.3 \mathrm{E}-06$ & - \\
Total & $3.9 \mathrm{E}-01$ & $0.5 \mathrm{E}+00$ & $2.8 \mathrm{E}+01$ & $5.0 \mathrm{E}+00$ \\
\hline
\end{tabular}



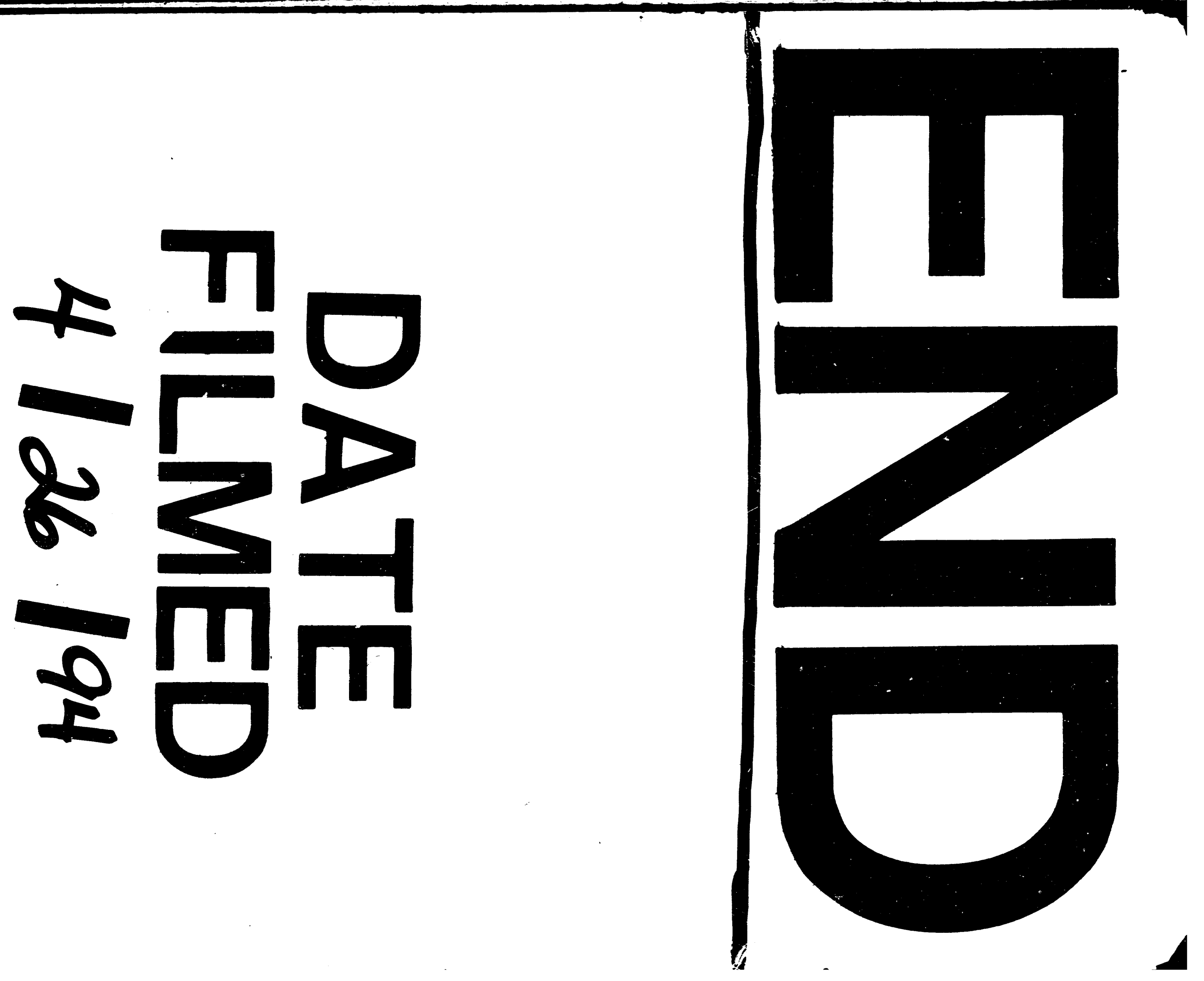